
erational Studies

\title{
REFERENCE
}

AL REPORT E-83-2

\section{FISHES OF SELECTED AQUATIC HABITATS ON THE LOWER MISSISSIPPI RIVER}

By C. H. Pennington, John A. Baker, Carolyn L. Bond

Environmental Laboratory

U. S. Army Engineer Waterways Experiment Station

P. O. Box 631 , Vicksburg, Miss. 39180

January 1983

Final Report

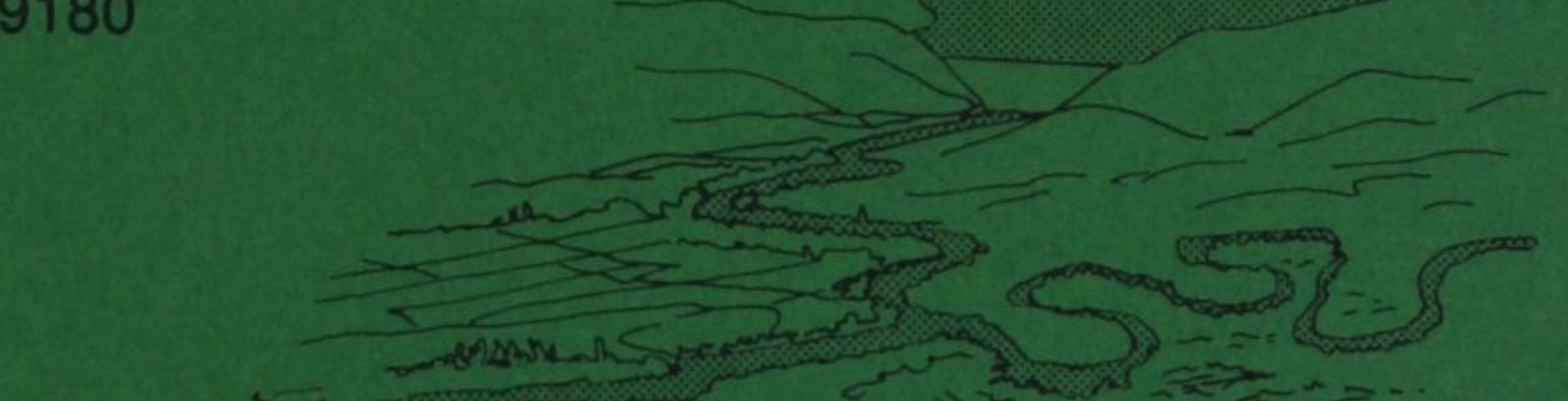

3.3
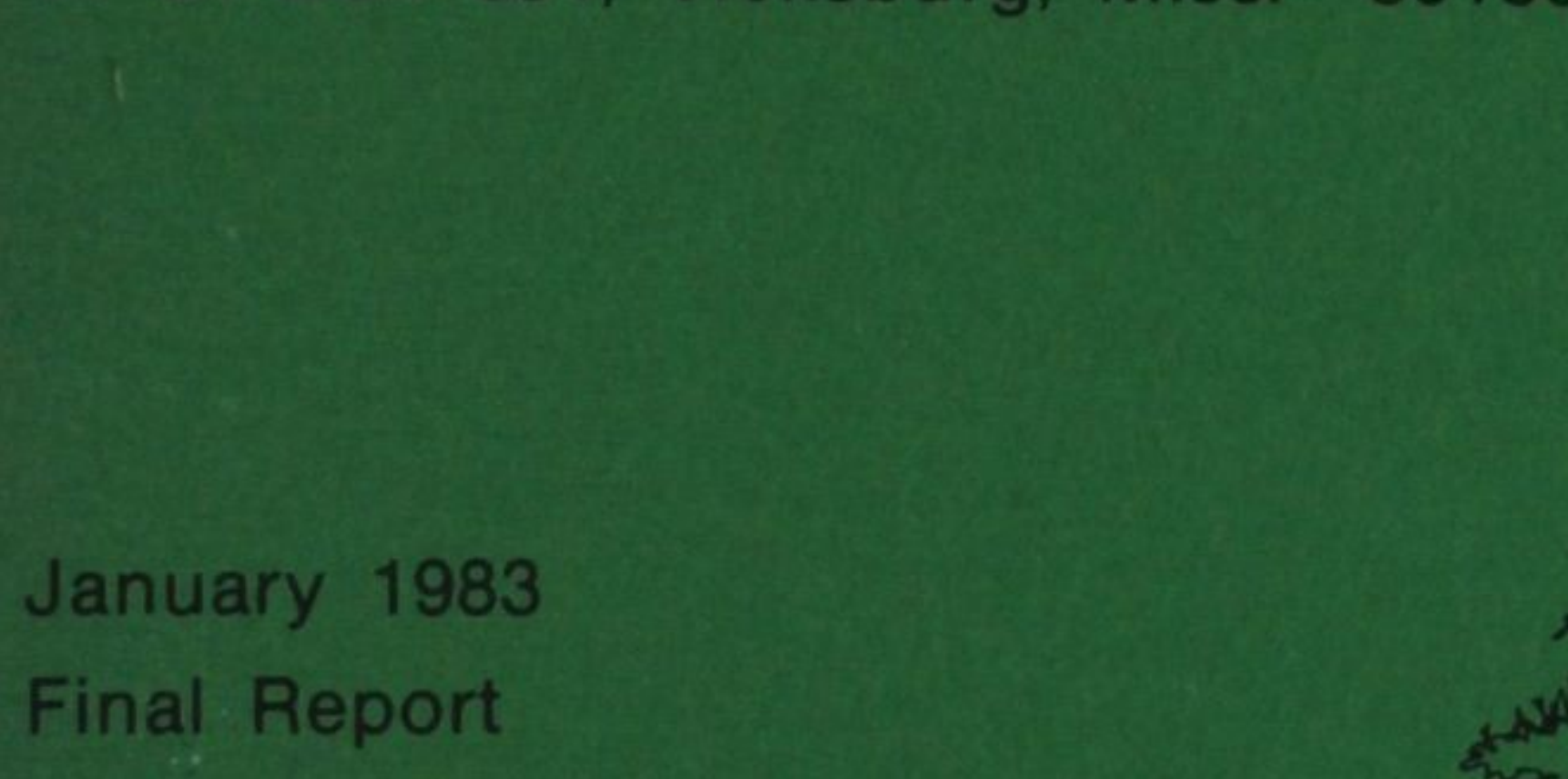
Unclassified

SECURITY CLASSIFICATION OF THIS PAGE (When Data Entered)

\begin{tabular}{|c|c|}
\hline REPORT DOCUMENTATION PAGE & $\begin{array}{c}\text { READ INSTRUCTIONS } \\
\text { BEFORE COMPLETING FORM }\end{array}$ \\
\hline $\begin{array}{l}\text { 1. REPORT NUMBER } \\
\text { Technical Report E-83-2 }\end{array}$ & 3. RECIPIENT'S CATALOG NUMBER \\
\hline 4. TITLE (and Subtitie) & $\begin{array}{l}\text { 5. TYPE OF REPORT \& PERIOD COVERED } \\
\text { Final report }\end{array}$ \\
\hline IHE LUWEK MISSISSII & 6. PERFORMING ORG. REPORT NUMBER \\
\hline $\begin{array}{l}\text { 7. AUTHOR(o) } \\
\text { C. H. Pennington, John A. Baker, Carolyn L. Bond }\end{array}$ & 8. CONTRACT OR GRANT NUMBER(B) \\
\hline $\begin{array}{l}\text { 9. PERFORMING ORGANIZATION NAME AND ADDRESS } \\
\text { U. S. Army Engineer Waterways Experiment Station } \\
\text { Environmental Laboratory } \\
\text { P. O. Box } 631 \text {, Vicksburg, Miss. } 39180\end{array}$ & $\begin{array}{l}\text { 10. PROGRAMELEMENT, PROJECT, TASK } \\
\text { AREA \& WORK UNIT NUMBERS } \\
\text { EWQOS Work Units VA } \\
\text { and VIIB }\end{array}$ \\
\hline $\begin{array}{l}\text { 11. CONTROLLING OFFICE NAME AND ADDRESS } \\
\text { Office, Chief of Engineers, U. S. Army } \\
\text { Washington, D. C. } 20314\end{array}$ & $\begin{array}{l}\text { 12. REPORT DATE } \\
\text { JaNUAYY } 1983 \\
\text { 13. NUMBER OF PAGES } \\
96\end{array}$ \\
\hline 14. MONITORING AGENCY NAME \& ADDRESS(If different from Controlling Office) & $\begin{array}{l}\text { 15. SECURITY CLASS. (of this roport) } \\
\text { UnClas ified } \\
\text { 15a. DECLASSIFICATION/DOWNGRADING } \\
\text { SCHEDULE }\end{array}$ \\
\hline
\end{tabular}

Approved for public release; distribution unlimited.

17. DISTRIBUTION STATEMENT (of the abstract ontered in Block 20, if different from Report)

\section{SUPPLEMENTARY NOTES}

Available from National Technical Information Service, 5285 Port Royal Road, Springfield, Va. 22151.

19. KEY WORDS (Continue on reverse side if necessary and ldentify by block number)

Aquatic Habitats

Dikes (Training structures) Revetment

Environmental quality

Fishes

20. ABSTFACT (Continu en reveres stide if necrearery and tdentify by block number)

This investigation is part of the Enviromental and Water Quality Operational Studies (EWQOS) sponsored by the Office of the Chief of Engineers. The basic objective of the EWQOS Program is to provide technology for the planning, design, and operation of Corps of Engineers projects to improve environmental quality. The purpose of this study was to investigate the ecological role of dikes and revetments in a riverine ecosystem.

(Continued) 


\section{ABSTRACT (Continued).}

Collections were made from the Lower Mississippi River near Greenville, Miss., to compare the relative value of four habitat types for fish. Sampling was conducted from April 1979 to September 1980 to describe species diversity, abundance, and distribution of fish from dike fields, revetted banks, natural banks, and an abandoned river channel.

Fish populations differed considerably among the four habitat types investigated. The greatest number of species was captured in the dike field habitat (53), followed in order by the abandoned channel (31), revetted banks (27), and natural banks (24).

The three dike fields were similar at most sampling periods in terms of species composition but were often different in the relative abundances of the constituent species. The two natural banks were generally similar in terms of both indices, while the revetted banks showed greater variability and overall lower similarity.

For comparable gears, numerical catch per unit effort (C/f) was seldom significantly different among habitats. Catches on revetted banks exceeded those on natural banks except during April 1979. The $\mathrm{C} / \mathrm{f}$ in the abandoned channel was approximately seven times that of any other habitat during November 1979 .

Biomass catch per unit effort $(\mathrm{C} / \mathrm{y})$ indicated a general ranking by habitat of revetted banks - dike fields - natural banks - abandoned channel, with two exceptions. During April 1979, the C/y of dike fields and natural banks exceeded that of revetted banks. During November $1979, \mathrm{C} / \mathrm{y}$ in the abandoned channel was greatest of all habitats. seasons.

Condition factors showed no significant differences among habitats or

Length frequency analysis showed differences in the size ranges of $\mathrm{fish}$ utilizing the four habitats. In particular, Age 0 fish of many species were abundant in dike fields, and, to a lesser extent, the abandoned channel. Mostly adult fish were collected at natural and revetted bank habitats. 
The study described in this report was sponsored by the office, Chief of Engineers, U. S. Army, under the Environmental and Water Quality Operational Studies (EWQOS) Program, Work Units VA, Environmental Impact of Selected Channel Alignment and Bank Revetment Alternatives in Waterways, and VIIB, Waterway Field Studies. The EWQOS Program has been assigned to the U. S. Army Engineer Waterways Experiment Station (WES) under the direction of the Environmental Laboratory (EL).

This report presents results of a study designed to document the distribution and relative abundance of fish associated with four different habitats found within the main-line levees along the Lower Mississippi River. Fish were collected from the river between miles 506 and 566 from April 1979 through September 1980.

The report was prepared by Dr. C. H. Pennington, Mr. John A. Baker, and Miss. Carolyn L. Bond under the supervision of Dr. Thomas D. Wright, Chief, Aquatic Habitat Group; Mr. Bob 0. Benn, Chief, Environmental Systems Division; Dr. Jerome L. Mahloch, Program Manager, EWQOS; and Dr. John Harrison, Chief, EL.

Special appreciation is expressed to Dr. Harold L. Schramm, Jr., University of Florida, and Mr. Michael E. Potter, EL, WES, for field support. Dr. Michael P. Farrell, Oak Ridge National Laboratory, is thanked for assistance with data analyses.

The Commanders and Directors of WES during the study and the preparation of this report were $\mathrm{COL}$ Nelson P. Conover, CE, and COL Tilford C. Creel, CE. Technical Director was Mr. F. R. Brown.

This report should be cited as follows:

Pennington, C. H., Baker, J. A., and Bond, C. L. 1983. "Fishes of Selected Aquatic Habitats on the Lower Mississippi River," Technical Report E-83-2, U. S. Army Engineer Waterways Experiment Station, CE, Vicksburg, Miss. 
PREFACE . . . . . . . . . . . . . . . . . . . . . . . . . . . . . 1

CONVERSION FACTORS, U. S. CUSTOMARY TO METRIC (SI) UNITS OF

MEASUREMENT . . . . . . . . . . . . . . . . . . . . 3

PART I: INTRODUCTION . . . . . . . . . . . . . . . . . 4

Navigation Structures............... . . 4

Objectives . . . . . . . . . . . . . . . . 6

PART II: STUDY AREA . . . . . . . . . . . . . . . . . . . . . . 7

General Description . . . . . . . . . . . . . . . 7

Sampling Locations ... . . . . . . . . . . . 7

PART III: MATERIALS AND METHODS . . . . . . . . . . . . 18

Description of Gear . . . . . . . . . . . . . . . . 18

Sampling Periods . . . . . . . . . . . . . . . 19

Analytical Methods . . . . . . . . . . . 20

PART IV: RESULTS . . . . . . . . . . . . . . . . . . . . . . . . . . 22

Dike Field Habitat . . . . . . . . . . . . . . . . . . . . 22

Bank Habitat . . . . . . . . . . . . . . . . . 30

Abandoned Channel Habitat . . . . . . . . . . . . . . 39

Length Frequencies . . . . . . . . . . . . . . . . 41

Condition Factors . . . . . . . . . . . . . . . . . . . . . . 48

Catch per Unit Effort . . . . . . . . . . . . . . . . 53

PART V: DISCUSSION . . . . . . . . . . . . . . . . . . . . 54

Comparison Among Habitats . . . . . . . . . . . . . . . . . 54

Comparison with Previous Studies . . . . . . . . . 56

PART VI: CONCLUSIONS AND RECOMMENDATIONS . . . . . . . . . . . . 61

Conclusions . . . . . . . . . . . . . . . . . . . 61

Recommendations . . . . . . . . . . . . . . 62

REFERENCES ...................... . . . 63

TABLES $1-19$

APPENDIX A: GLOSSARY OF TERMS . . . . . . . . . . . . . . . . . . A1 
U. S. customary units of measurement used in this report can be converted to metric (SI) units as follows:

\begin{tabular}{|c|c|c|}
\hline Multiply & By & To Obtain \\
\hline cubic feet per second & 0.02831685 & cubic metres per second \\
\hline cubic yards per day & 0.7645549 & cubic metres per day \\
\hline feet & 0.3048 & metres \\
\hline feet per second & 0.3048 & metres per second \\
\hline inches & 25.4 & millimetres \\
\hline miles (U. S. statute) & 1.609347 & kilometres \\
\hline pounds (mass) & 0.4535924 & kilograms \\
\hline
\end{tabular}




\section{FISHES OF SELECTED AQUATIC HABITATS ON}

\section{THE LOWER MISSISSIPPI RIVER}

\section{PART I: INTRODUCTION}

1. This investigation is part of the Environmental and Water Quality Operational Studies (EWQOS) Program sponsored by the Office, Chief of Engineers, and is being managed by the U. S. Army Engineer Waterways Experiment Station (WES). The basic objective of the EWQOS Program is to provide new or improved technology for the planning, design, construction, and operation of Corps of Engineers (CE) projects in an effort to solve selected environmental quality problems. A key element of EWQOS is the use of field studies to evaluate and document the utility of new or improved methodologies developed within the program.

2. One major problem area identified by $C E$ field offices as being of high priority was the environmental impacts of project activities on waterways (Keeley et al. 1978). Specifically, it was determined that EWQOS research should develop field office guidance to address environmental features of dikes and revetments. Such structures are found in waterways in many parts of the United States, and are very common along the Mississippi River and its tributaries.

\section{$\underline{\text { Navigation Structures }}$}

3. Dikes have been used by the CE for many years to improve navigation on the Nation's major waterways. The principal uses of dikes are to adjust main channel width, depth, and alignment, and to close secondary channels. Dike structures are probably the most effective means of channel alignment and contraction in use today.

4. Dikes are constructed of permeable wooden piles or, more typically in present times, of relatively impermeable stone riprap. Dikes may be singular or placed one after another along a bank forming a dike field. Generally, dikes in the Lower Mississippi River are of the 
transverse type, which extend from the bank perpendicular to the current. An extension, or L-head, may be placed at the offshore end of a dike parallel to the current to retard scouring and turbulence. Vane dikes, which are placed in the channel parallel or oblique to the current, are also used.

5. Water is shunted by a dike toward the opposite riverbank and, if this bank is stable, the resulting narrower channel is deepened by scouring. Dikes are typically placed on the convex side, or point bar, in a bendway, or in straight reaches, to achieve some degree of channel sinuosity and resulting contraction. Suspended sediments are deposited downstream of individual dikes due to the reduction of current velocities caused by the structure. In dike fields, sediment accretion may be appreciable, and these accumulated sediments, which may in some instances form a bar, further serve to confine the flow of water. Slackwater pools may be found downstream of transverse dikes at low river stages in cases where sediment accretion has not completely filled in these areas.

6. Revetments are installed along riverbanks to prevent bank caving and erosion. Revetments are often located on the concave bank in bendways, and downstream and across the river from dike fields, where increased currents caused by the dikes promote bank erosion. They are also placed in areas where erosion threatens levees. These structures are of many types, but generally consist of erosion-resistant materials which are placed on a pregraded bank from the top of the bank line to the toe of the channel. Construction materials include stone riprap, asphalt pavement, and articulated concrete mattress. In the past, asphalt was used instead of riprap for bank paving. Willow mats were also used in the distant past.

7. When riverbanks are revetted, much of their natural character is altered. 0lder revetment structures that have become extensively vegetated with willow and cottonwood trees and a variety of sedges, grasses, and shrubs may have different values as aquatic habitat than new revetments. The type of material composing the revetment may also be an important variable in determining the habitat value of revetment structures. Another factor is the sinuosity of the bank line upon which 
the revetment is placed. A sinuous bank would tend to have more variable velocities than would a straight bank line due to eddies and upstream flow.

8. As of 30 September 1980 , there were over 400 dikes on the Lower Mississippi River having a combined length of 184 linear miles.* In addition, there are 778 linear miles of revetted bank. Under the Mississippi River and Tributaries (MR\&T) Project, the CE has an additional 190 miles of revetment and 112 miles of dikes planned before the MR\&T Project completion date of November 1996.

9. Because of the abundance of revetted banks and dikes in many of the major river systems of the United States, information about the environmental effects of these structures is valuable to CE Districts and Divisions for use in impact assessments and for environmentally compatible planning, design, and construction of these structures.

\section{$\underline{\text { Objectives }}$}

10. The primary objective of this report is to quantitatively describe fish species diversity, abundance, and distribution in four habitats found in the Lower Mississippi River. The habitats chosen for study were dike fields, revetted banks, natural banks, and an abandoned river channel. Comparisons are made among the habitats to better understand the role of dikes and revetments to the riverine environment.

* A table of factors for converting U. S. customary units of measurement to metric (SI) units is presented on page 3 . 


\section{PART II: STUDY AREA}

\section{General Description}

11. The study area encompassed a 60-mile reach of the Lower Mississippi River (Figure 1) near Greenville, Miss. (river miles 506 to 566). The study area is confined on both sides by main-line levees constructed by the $\mathrm{CE}$ for flood-control purposes. Leveed floodplain width ranges from 2 to 6 miles. Backwater habitats between the levees and the main river channel have indirect or seasonal connections with the river and are often submerged during floods. There are no tributaries entering the river within the study area.

12. Average discharge of the river at Vicksburg, Miss., $*$ is about $561,000 \mathrm{ft}^{3} / \mathrm{sec}$. Recorded discharges have ranged from about $100,000 \mathrm{ft}^{3} /$ sec at extreme low river stage to $2,700,000 \mathrm{ft}^{3} / \mathrm{sec}$ at high stages, with a $60-\mathrm{ft}$ difference in water level. The average water velocity within the main channel is from 3 to $6 \mathrm{ft} / \mathrm{sec}$ with a maximum recorded velocity of $15 \mathrm{ft} / \mathrm{sec}$ during extremely high flows. The average hydrograph for the river at Vicksburg shows highest discharges occurring from February through March and lowest discharges occurring from July through October. The estimated average bed-load transport at Vicksburg is $1,000,000 \mathrm{yd}^{3} /$ day.

13. The climate of the study area and the navigation and floodcontrol objectives for the Lower Mississippi River are described in detail by Miller (1980).

\section{$\underline{\text { Sampling Locations }}$}

14. Habitats associated with navigation structures and unaltered areas were sampled for fish during 1979 and 1980. The navigation structures included three dike fields and two revetted banks. Other habitats included two natural banks and an abandoned river channel.

* A major gaging and data collection point for the Lower Mississippi River located 65 miles downstream from the study area. 


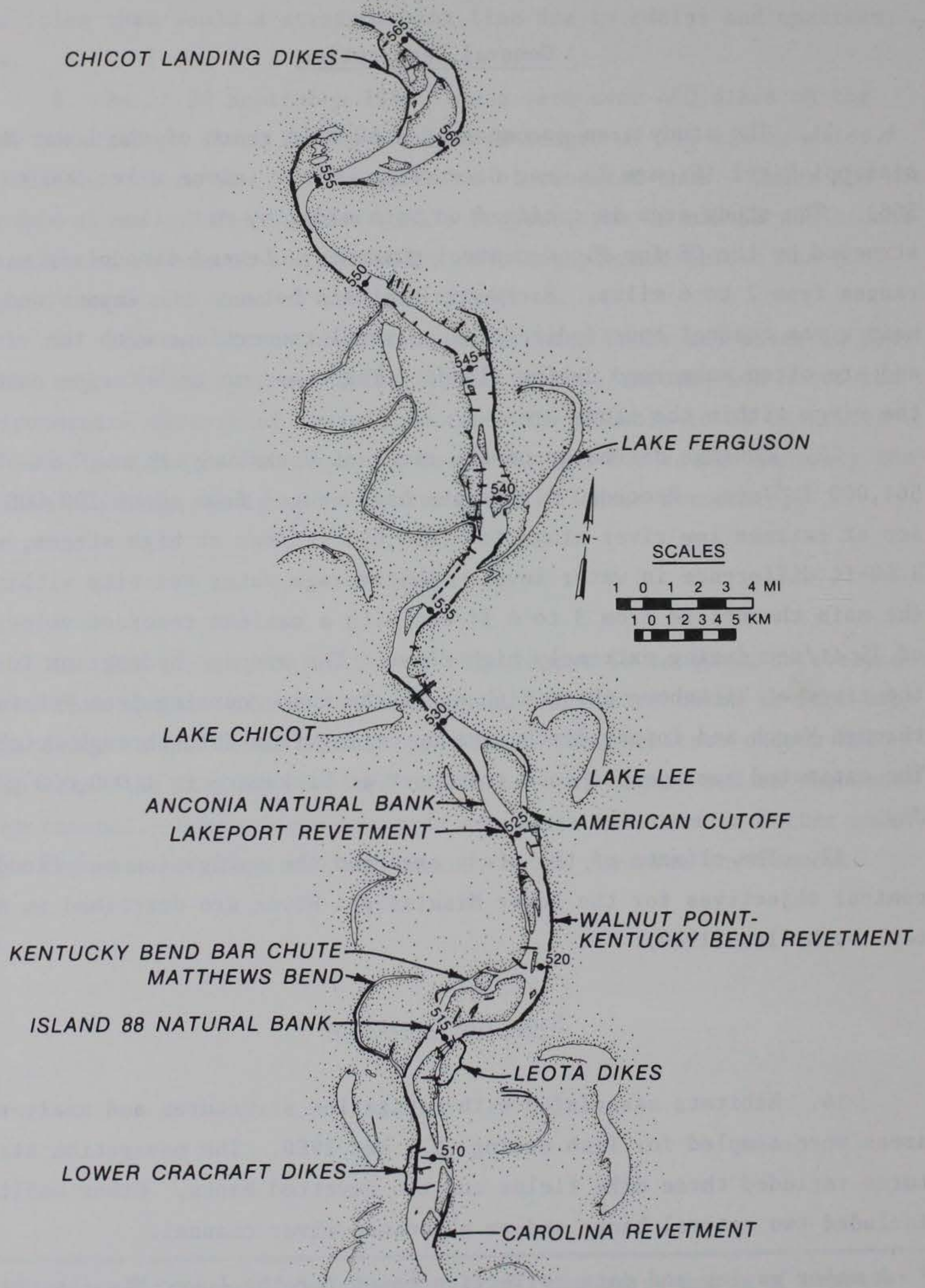

Figure 1. Map of study area 


\section{Dike fields}

15. A dike field habitat is defined as that portion of the river encompassing a series of transverse and/or vane dikes and the associated pools and sandbars. The border between dike field habitats and the main channel is the $10-\mathrm{ft}$ low-water reference plane (LWRP). Current velocities in dike fields vary from slack at low-water stages to almost as swift as is found in the main channel during high-water stages.

16. The Lower Cracraft Dike Field consists of three transverse, stone dikes (Figure 2). These dikes were constructed for the dual purpose of secondary channel closure and point bar stabilization. This dike field is a stepped-down design. Dike $1 *$ is $1834 \mathrm{ft}$ long with elevations of +20 and $+15 \mathrm{ft}$ LWRP at the bank and main channel ends, respectively. Dike 2 is $3620 \mathrm{ft}$ long with elevations of +18 and $+13 \mathrm{ft}$ LWRP at the bank and main channel ends, respectively. Dike 3 is $4320 \mathrm{ft}$ long; elevations at the bank and main channel ends are +15 and $+10 \mathrm{ft}$ LWRP. Dikes 1 and 2 were constructed in 1971; Dike 3 was constructed in 1972. Extensive sand and gravel middle bars occur between succeeding dikes and over a 3-mile reach of river downstream from the third dike. These middle bars, the main axis of which is parallel to the main channel flow, isolate extensive pools between the riverbank and the middle bars during low-water stages. Isolated areas of willow trees occur on the middle bars. Dense woods along the bank approximately 1 mile below Dike 3 are inundated at higher flows. Substrate types range from mud to coarse sand and gravel. Distribution of substrate types within dike field pools changes with river stage. During high flows, coarse sand and gravel predominate. As water levels drop, mud and fine sand become the most dominant substrate type.

17. The Leota Dike Field consists of three transverse, stone dikes built in 1968 for the dual purpose of secondary channel closure and point bar stabilization (Figure 3). This dike field is also a stepped-down design. Dike 1 is $1080 \mathrm{ft}$ long and has bank and main channel end elevations of +21 and $+16 \mathrm{ft}$ LWRP, respectively. Dike 2 is $2340 \mathrm{ft}$ long with

* Dikes are numbered sequentially from upstream to downstream. 


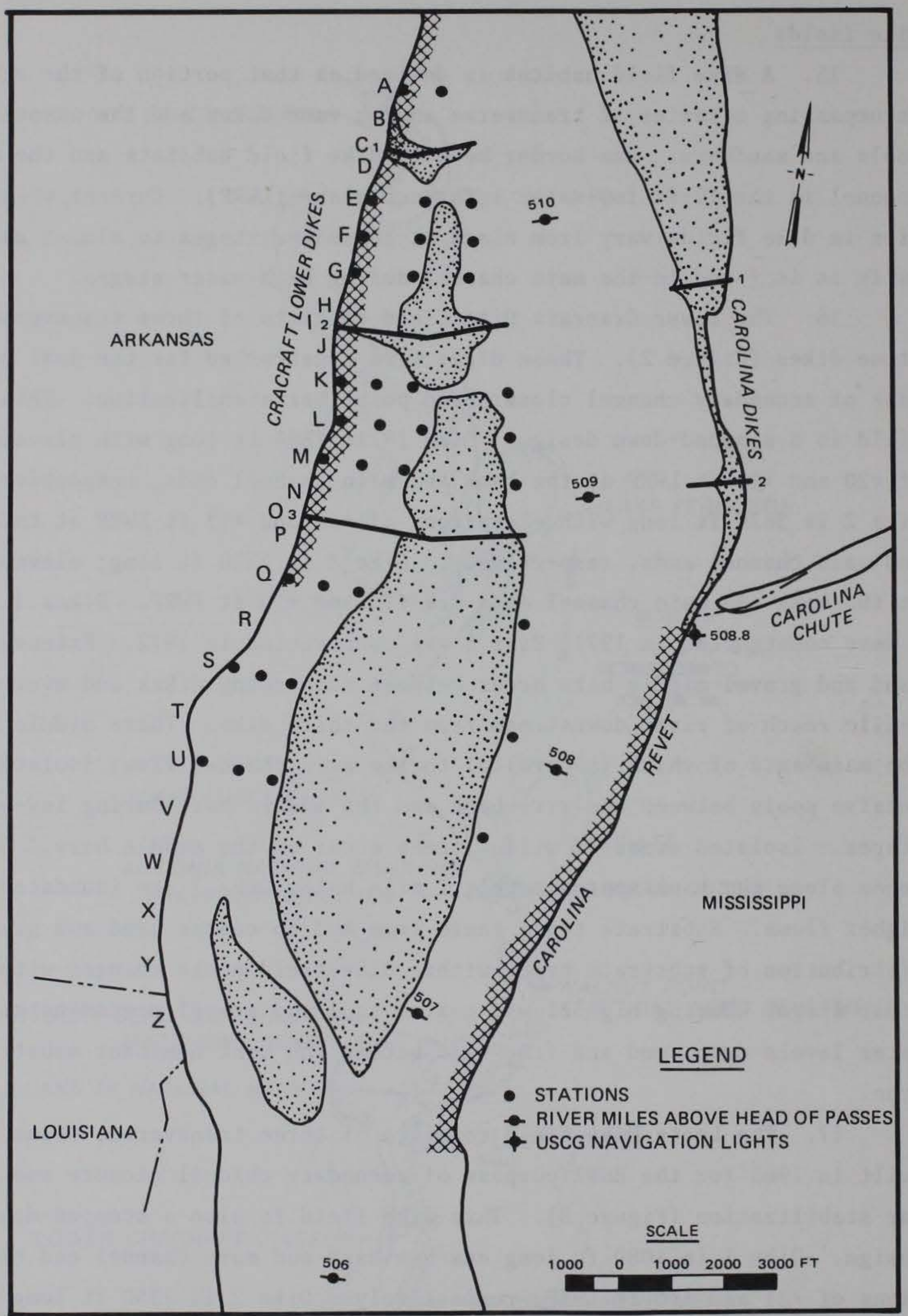

Figure 2. Map of the Lower Cracraft Dike Field (USCG $=$ U. S. Coast Guard) 


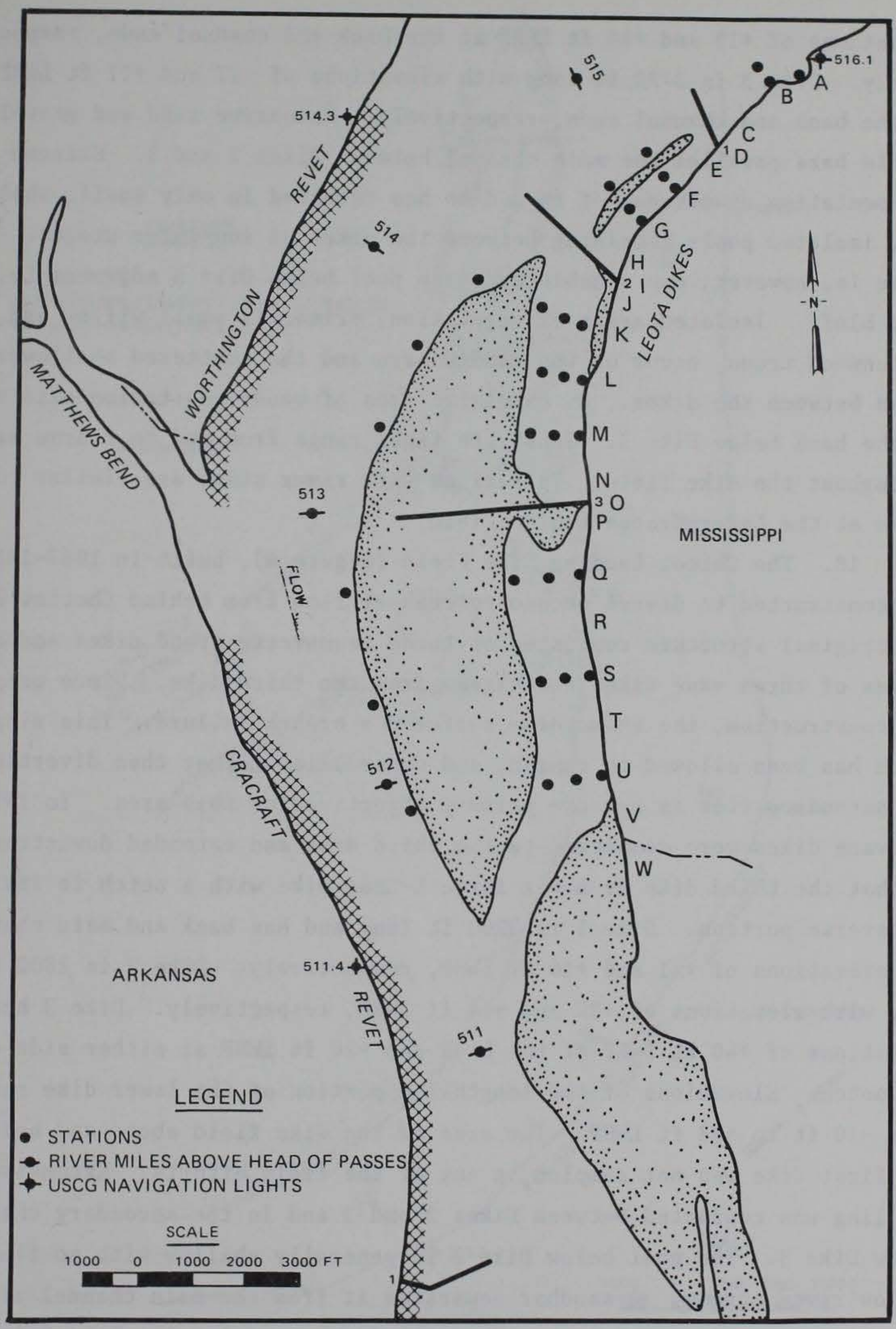

Figure 3. Map of the Leota Dike Field 
elevations of +19 and $+14 \mathrm{ft}$ LWRP at the bank and channel ends, respectively. Dike 3 is $3720 \mathrm{ft}$ long with elevations of +17 and $+11 \mathrm{ft}$ LWRP at the bank and channel ends, respectively. Extensive sand and gravel middle bars parallel the main channel between Dikes 2 and 3 . Extreme sedimentation downstream of each dike has resulted in only small, shallow, isolated pools remaining between the dikes at low-water stages. There is, however, one sizable and deep pool below Dike 3 adjacent to a clay bluff. Isolated areas of vegetation, primarily small willow and cottonwood trees, occur on the middle bars and the scattered shallower areas between the dikes. An extensive area of woody vegetation exists on the bank below Dike 3. Substrate types range from mud to coarse sand throughout the dike field. Variations with river stage are similar to those at the Lower Cracraft Dike Field.

18. The Chicot Landing Dike Field (Figure 4), built in 1967-1969, was constructed to divert secondary channel flow from behind Choctaw Bar. The original structure consisted of three transverse stone dikes and a series of three vane dikes downstream from the third dike. Since original construction, the third dike suffered a breach failure. This sizable notch has been allowed to remain, and controlling rather than diverting the secondary flow is now the primary objective for this area. In 1975, the vane dikes were connected to the third dike and extended downstream so that the third dike is now a large L-head dike with a notch in its transverse portion. Dike 1 is $2200 \mathrm{ft}$ long and has bank and main channel end elevations of +31 and $+16 \mathrm{ft}$ LWRP, respectively. Dike 2 is $2800 \mathrm{ft}$ long with elevations of +30 and $+14 \mathrm{ft}$ LWRP, respectively. Dike 3 has elevations of $+40 \mathrm{ft}$ LWRP at the bank and $+20 \mathrm{ft}$ LWRP at either side of the notch. Elevations of the lengthwise portion of the lower dike range from $-10 \mathrm{ft}$ to $+38 \mathrm{ft}$ LWRP. The area of the dike field above and below the first dike was not sampled in any of the field efforts. Extensive sampling was conducted between Dikes 2 and 3 and in the secondary channel below Dike 3. The pool below Dike 2 is generally shallow with no flow at low river stages. A sandbar separates it from the main channel at all but the lower end of the pool. The secondary channel below Dike 3 is separated from the main channel by Choctaw Bar. 


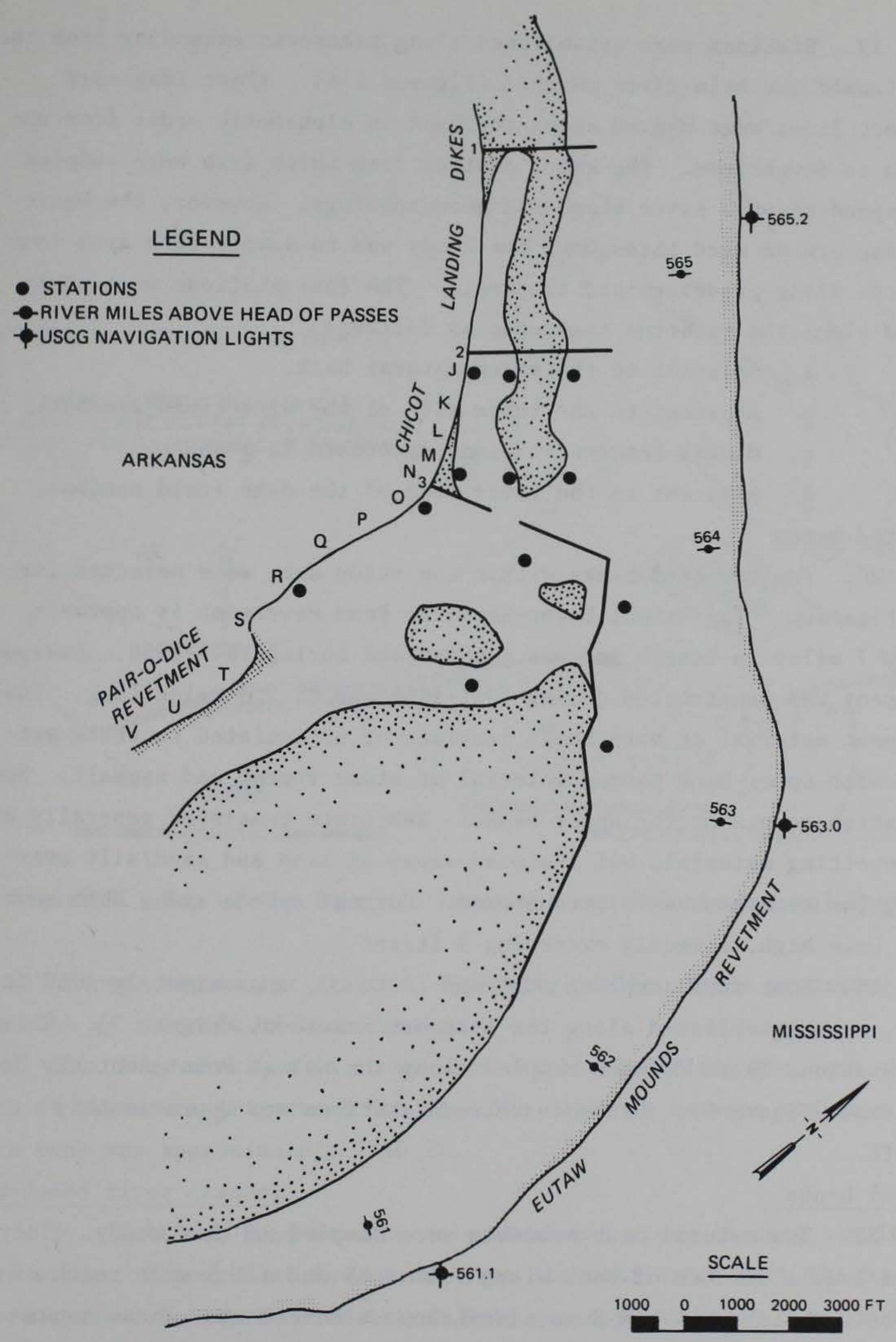

Figure 4. Map of the Chicot Landing Dike Field 
19. Stations were established along transects extending from the bank toward the main river channel (Figures 2-4). These imaginary transect lines were marked along the bank in alphabetic order from upstream to downstream. The exact station from which fish were sampled was dependent upon river stage and geomorphology. However, the basic sampling scheme used throughout the study was to sample fish from four stations along predetermined transects. The four stations were positioned along the selected transects as follows:

a. Adjacent to the steep natural bank.

b. Adjacent to the inner side of the dike field sandbar.

c. Midway between stations described in a and $\underline{b}$.

d. Adjacent to the river side of the dike field sandbar.

Revetted banks

20. Two revetted banks within the study area were selected for investigation. The Walnut Point-Kentucky Bend Revetment is approximately 7 miles in length and was constructed during 1944-1968. Lakeport Revetment was constructed during 1961-1962 and is 1.2 miles long. The revetment material at both banks consists of articulated concrete mattress with upper-bank paving material of stone riprap and asphalt. Some vegetation occurs on the upper banks. Substrate consisted generally of the revetting material, but isolated areas of sand and sand/silt overlaying the revetment were encountered. Current speeds along both revetments were high, commonly exceeding $3 \mathrm{ft} / \mathrm{sec}$.

21. Four fish sampling stations (A to D), approximately $1750 \mathrm{ft}$ apart, were established along the Lakeport Revetment (Figure 5). Thirteen stations (A to M) were sampled along the Walnut Point-Kentucky Bend Revetment (Figure 6). Distance between stations was approximately $2600 \mathrm{ft}$.

Natural banks

22. Two natural bank habitats were sampled in this study. They were a 1-mile stretch of bank along Island 88 and a 1.5-mile reach of bank between Lakeport and Sunnyside-Lakeport Revetment. These banks varied from hard clay and mud to fine sand. Currents were considerably reduced, compared to those in the main channel and along revetted banks, 
RIVER MILES ABOVE HEAD OF PASS

NOTE: CONTOURS BASED ON 1978 HYDROGRAPHS ARE IN FEET RELATIVE TO 1974 ANNUAL LOW-WATER REFERENCE

PLANE
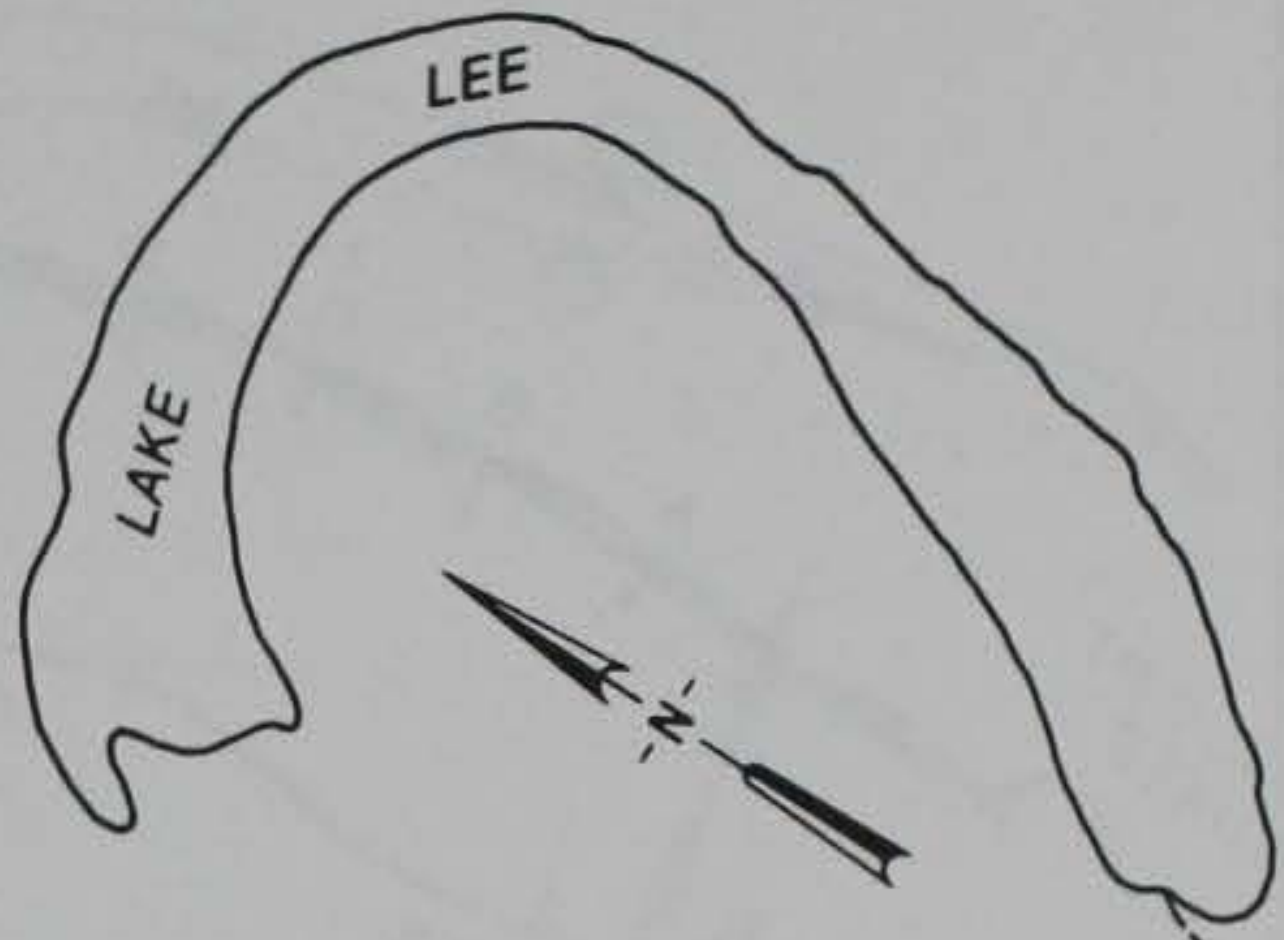

MS

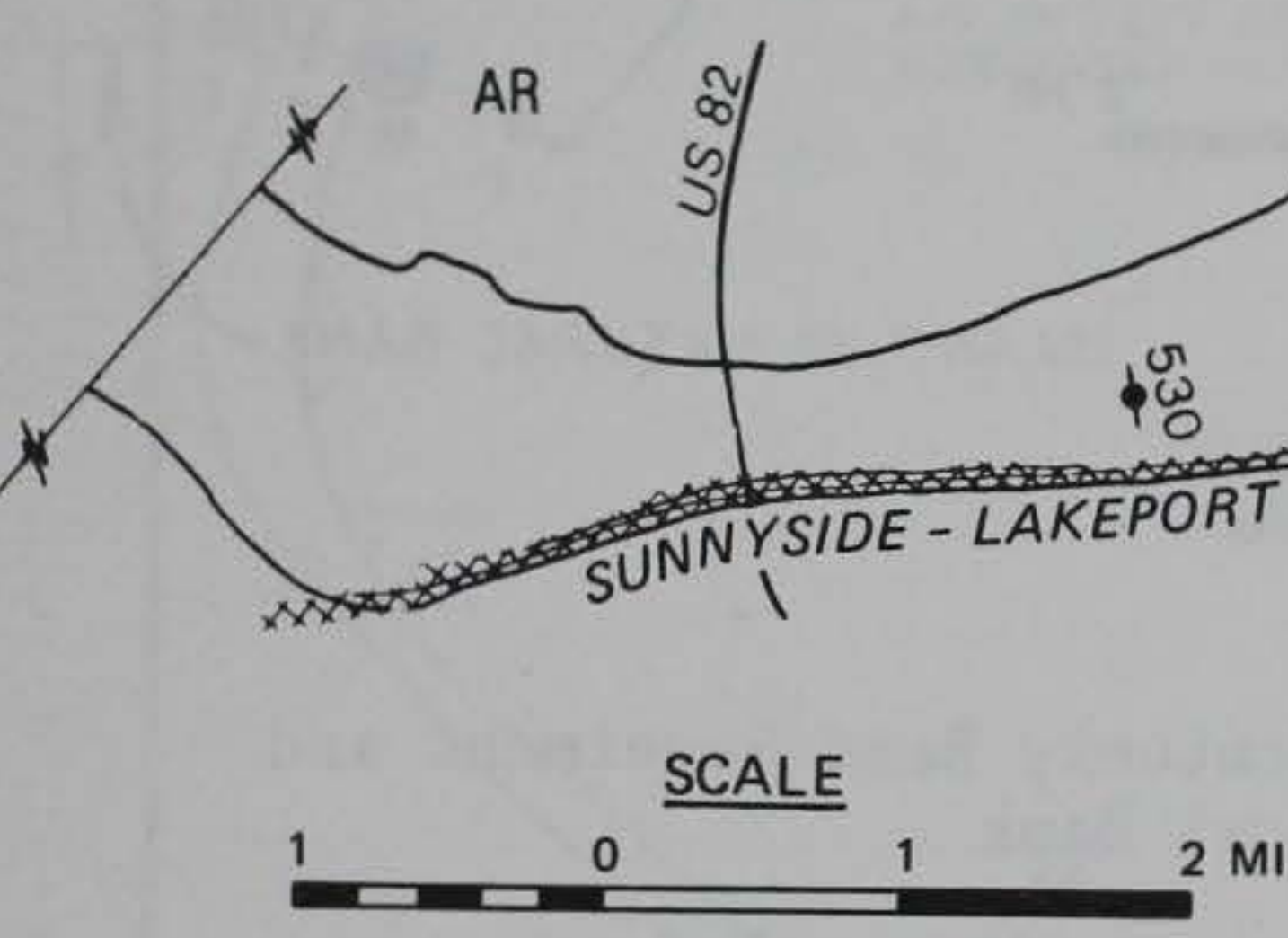

ANCONIA NATURAL BANK

LAKEPORT REVETMENT

Figure 5. Map of the Lakeport Revetment and Anconia Natural Bank

at all except high-water stages. Typically, fallen trees protruded from the bank as a result of bank caving.

23. Four stations (A to D) were established along the bank at each of the sites (Figures 5 and 6 ). The distance between stations at each bank was approximately $1750 \mathrm{ft}$.

Abandoned river channel

24. Matthews Bend was the only abandoned river channel sampled in this study. Measured at low water, from its confluence with the main river channel to its head, Matthews Bend was approximately 5 miles long. The depth increased from upstream to downstream. The substrate was predominantly mud. The adjacent floodplain is heavily wooded with living 


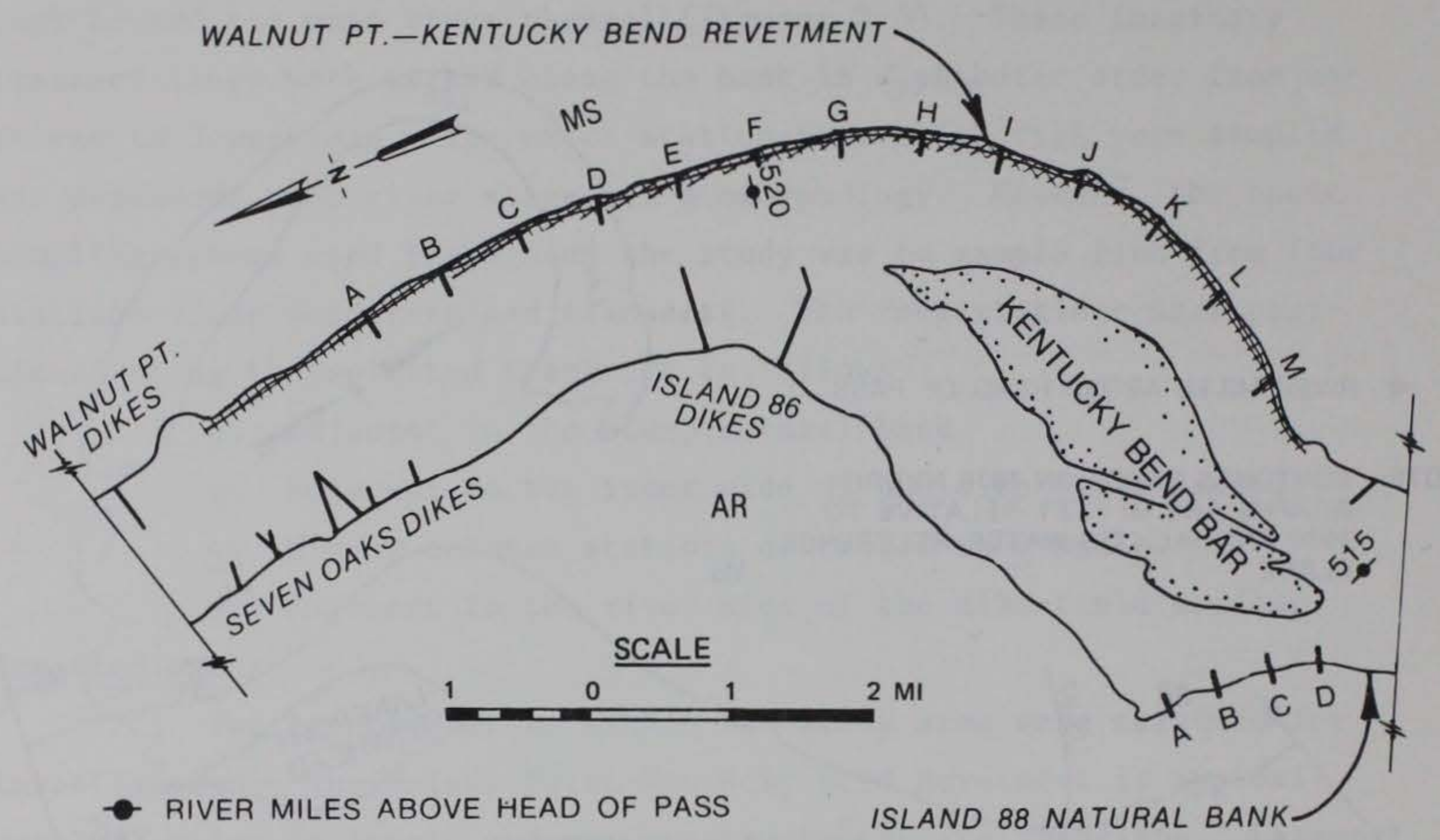

NOTE: CONTOURS BASED ON 1978 HYDROGRAPHS ARE IN FEET RELATIVE TO 1974 ANNUAL LOW-WATER REFERENCE PLANE

Figure 6. Map of Walnut Point-Kentucky Bend Revetment and Island 88 Natural Bank

and dead trees (primarily willow) and is periodically inundated with changing river stages.

25. Six sampling stations were established in the abandoned river channel (Figure 7). Two stations each were sampled in upper, middle, and lower reaches of Matthews Bend. The two stations in each reach were on opposite sides of the abandoned river channel. 


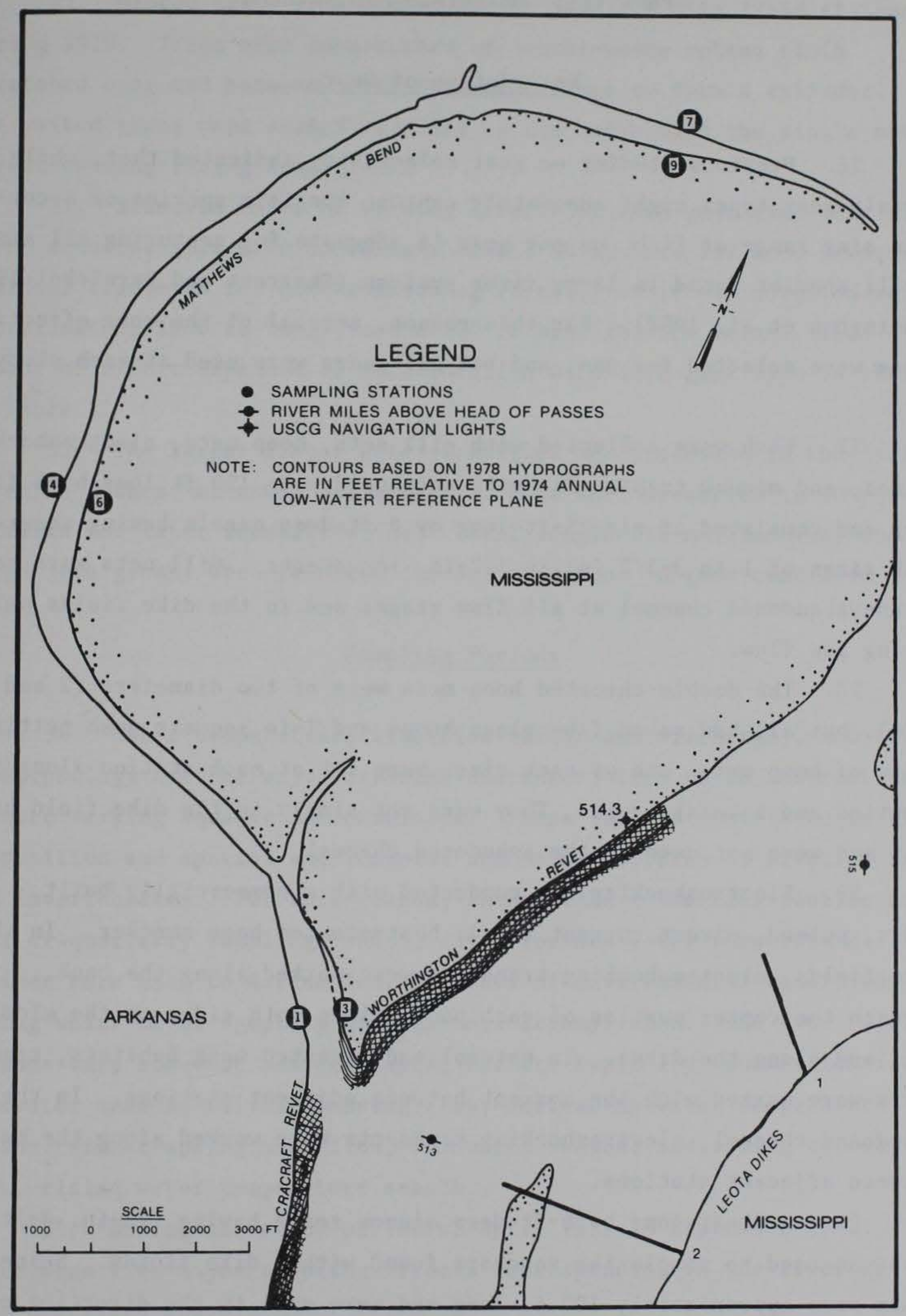

Figure 7. Map of Matthews Bend 


\section{Description of Gear}

26. Previous studies on gear selectivity indicated that, while certain gear types might adequately capture specific species or a certain size range of fish, no one gear is adequate for capturing all sizes of all species found in large river systems (Starrett and Barnickol 1955; Pennington et al. 1980). For this reason, several of the more effective gears were selected for use, and not all gears were used at each study site.

27. Fish were collected with gill nets, hoop nets, electroshocker, seines, and minnow traps. The gill nets used were $150 \mathrm{ft}$ long by $8 \mathrm{ft}$ deep and consisted of six 25-ft-long by 8 -ft-deep panels having square mesh sizes of 1 to $3-1 / 2$ in. in 1/2-in. increments. Gill nets were set in the abandoned channel at all flow stages and in the dike fields only during low flow.

28. The double-throated hoop nets were of two diameters ( 2 and $3 \mathrm{ft}$ ), but all had seven fiberglass hoops and 1-in.-square mesh netting. Pairs of hoop nets, one of each size, were set at each station along the revetted and natural banks. They were set singly in the dike field habitat and were not used in the abandoned channel.

29. Electroshocking was conducted with a commercially built, 230-v, pulsed, direct current (d-c), boat-mounted boom shocker. In the dike fields, electroshocking transects were worked along the bank, through the center portion of each pool, along both sides of the middle bar, and along the dikes. In natural and revetted bank habitats, transects were worked with the current between adjacent stations. In the abandoned channel, electroshocking transects were worked along the banks between adjacent stations.

30. A $30-\mathrm{ft}$-long by 4-ft-deep minnow seine having $1 / 8$-in. delta mesh was used to sample the sandbars found within dike fields. Seine hauls were approximately $100 \mathrm{ft}$ long and were made in the direction of the current, when a current existed. 
31. Minnow traps were fished at all feasible dike field stations during 1979. Traps were constructed of coarse-weave cotton cloth stretched over and between 8-in.-diam wire rings to form a cylinder. The baited traps were staked parallel to the banks with the single net throat opening facing downstream.

32. Standard units of fishing effort for each gear type were: 24-hr sets for gill nets and minnow traps; 48-hr sets for hoop nets; individual transects for electroshocking (usually of 10-min duration and approximately $1000 \mathrm{ft}$ long); and a 100-ft haul for the seine. The amount of effort expended in each location with each gear type is shown in Table 1.

33. The larger fishes were identified and processed in the field. Juvenile fishes, minnows, and unusual fishes were preserved in 10-percent formalin for later identification. Total length (in millimetres) and weight (in grams) were recorded for all specimens in good condition.

\section{$\underline{\text { Sampling Periods }}$}

34. Water temperature, riverflow (stage and discharge), and river geomorphology are the major riverine characteristics which interact to produce varying aquatic macrohabitats. These factors contribute to the composition and spatial and temporal abundance patterns of riverine fish and invertebrates. For this reason, rather than conducting routine annual or quarterly sampling, annual riverflow and water temperature regimes were used to define four key sets of environmental conditions during which major sampling efforts were accomplished. The four river seasons vary somewhat between years, but are typically: summer low flow, warmwater season; fall increasing flow, decreasing water temperature season; winter/spring high flow, coldwater season; and spring decreasing flow, rising water temperature season.

35. During the study period of April 1979 to September 1980, there were five major sampling efforts corresponding to the river seasons described above: 
a. 16 April to 4 May 1979, winter/spring high flow.

b. 19 June to 29 June 1979, spring decreasing flow.

c. 18 September to 28 September 1979 , summer low flow.

d. 5 November to 19 November 1979, fall increasing flow.

e. 7 September to 19 September 1980, summer low flow.

During 1979, all habitats except the Chicot Landing Dike Field were sampled in each of the four river seasons. Chicot Dike Field was sampled in 1979 only at the low flow river stage (September). During 1980, al1 habitats except Matthews Bend were sampled only during the low flow stage.

\section{Analytical Methods}

36. Mean numerical catch per unit of effort $(C / f), *$ mean total weight of fish per unit of effort $(\mathrm{C} / \mathrm{y})$, and mean number of species per unit of effort were calculated for each habitat and each gear type except minnow traps during each sampling period. A one-way analysis of variance (ANOVA) by gear type was used to determine whether significant differences existed among habitats during a sampling period. Data were transformed as $\log (\mathrm{X}+1)$ prior to analysis, as is generally appropriate for species abundances (Green 1979). Subsequent to the ANOVA, Duncan's New Multiple Range Test was used to examine the pattern of differences. A nested ANOVA by gear type was used to determine if significant differences existed among habitats during a sampling period. The 5-percent significance level was used in all analyses.

37. Similarity and dissimilarity coefficients were calculated for each habitat pair at each sampling date using data from all gear types. The similarity coefficient (coefficient of community) is based on the presence-absence component of the data while the dissimilarity (percentage similarity) coefficient incorporates species densities (Boesch 1977). For ease of comparison, dissimilarity values were subtracted from 1.0 to convert them to similarities (Boesch 1977).

* See Appendix A for a glossary of terms. 
38. Species diversity values (base 10) were calculated from data collected by all gear types using the Shannon formula (Peet 1974).

39. Condition factors (Ricker 1971) were calculated for gizzard shad, freshwater drum, channel catfish, blue catfish, flathead catfish, and river carpsucker.* Condition factors were compared using Duncan's New Multiple Range Test.

* Scientific names are given in Table 2. 
40. During this investigation, a total of $14,537 \mathrm{fish}$ weighing 5,482 lb were captured. Fifty-seven species and nineteen families were represented (Table 2). Gizzard shad were the most numerically abundant (35.3 percent of the total) and most abundant by weight (16.4 percent of the total biomass). Two other species comprised at least 5 percent of the numeric catch: river shiner (10.1 percent) and the silverband shiner (5.9 percent). Carp ranked seventeenth in numerical abundance ( 1.3 percent of the total) but second in weight ( 14.1 percent of the total biomass). Flathead catfish and blue catfish comprised 14.0 and 9.3 percent of the total weight, respectively.

41. A review of the species and numbers of fish taken at each habitat is presented in this section. Other general comments regarding the fish populations and gear efficiency also are given.

\section{Dike Field Habitat}

\section{Lower Cracraft Dike Field}

42. A total of 5405 fish representing 45 species were captured at this dike field. The number of species collected during a sampling period ranged from 12 in April 1979 to 37 in June 1979. Gizzard shad and river shiner were numerically dominant in all collections except September 1979, when gizzard shad comprised only 3.1 percent of the catch, and during April 1979, when the river shiner was not collected (Table 3). Because high river stages prevented the use of seines during April, the absence of river shiners from the collections (and other Cyprinidae as well) does not necessarily imply absence from the habitat. Other species constituting significant relative percentages were emerald and silverband shiners, silvery minnow, and inland silversides.

43. Sport-commercial species collectively comprised 18.6 percent of the total number of individuals (Table 3). Blue catfish, flathead catfish, and channel catfish ranked third, eighth, and twelth, respectively; these species together constituted just over 10 percent relative 
abundance. River carpsucker and freshwater drum were also numerically important sport-commercial species.

44. Gizzard shad dominated the catch by weight (Table 4) at Cracraft. Flathead, blue, and channel catfishes ranked second, third, and sixth, totaling over one third of the weight. Carp comprised only 0.4 percent of the numbers but accounted for 10.4 percent by weight. Together, the 10 dominant species constituted 86.8 percent of the total weight.

45. Diversity at Lower Cracraft Dike Field ranged from 0.89 during April 1979 to 2.72 during June 1979 (Figure 8). With the exception of the April 1979 high-water collection, diversity was lower here than in any other dike field.

Leota Dike Field

46. Forty-six species totaling 3397 fish were collected from Leota Dike Field during the five sampling efforts (Table 5). The number of individuals (161) and species (12) was lowest during the April 1979 high-water period. The greatest number of species (36) was collected during June 1979, and the number of fish collected (1446) was greatest during September 1980.

47. Gizzard shad and river shiner dominated the catch numerically (Table 5), together comprising over one third of the total number of individuals. Two other forage species, emerald shiner (7.0 percent) and blacktail shiner ( 6.7 percent), also made up appreciable percentages of the ichthyofauna at Leota. Sport-commercial species were more abundant at Leota than at any other dike field, comprising 23.4 percent of the total (Table 5). Channel, flathead, and blue catfishes were abundant, together accounting for 11.7 percent. River carpsucker (4.0 percent) and freshwater drum (2.9 percent) also contributed significantly at this habitat. Four sport species were numerous here relative to most other habitats: white bass ( 1.3 percent), sauger ( 1.0 percent), bluegill (0.9 percent), and white crappie ( 0.7 percent)

48. Carp, flathead catfish, and river carpsucker dominated the catch by weight at Leota Dike Field (Table 6). Four other sportcommercial species (channel catfish, smallmouth buffalo, blue catfish, 


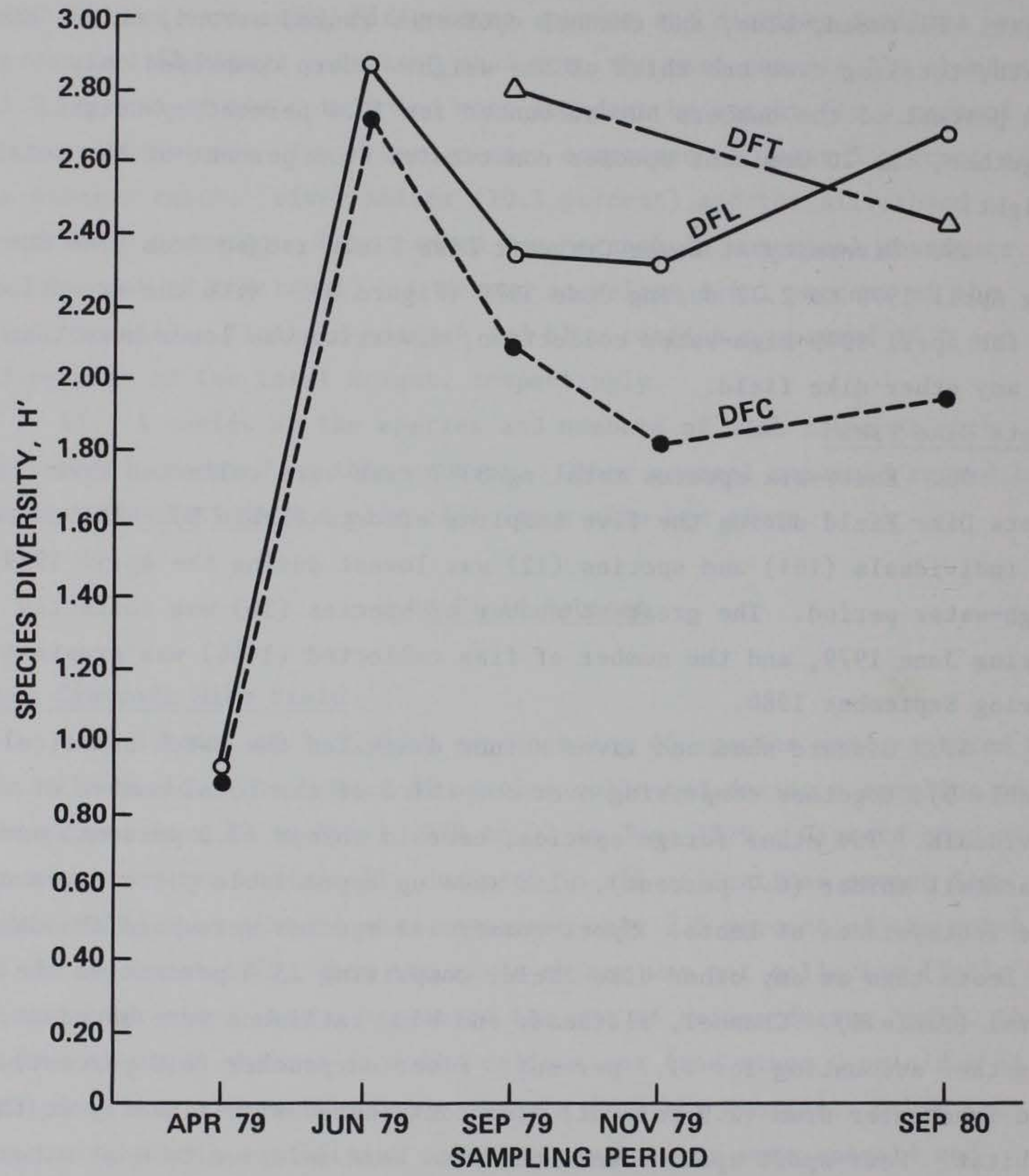

Figure 8. Species diversity of three Mississippi River dike fields. DFC = Lower Cracraft Dike Field; DFL = Leota Dike Field; DFT $=$ Chicot Landing Dike Field 
and freshwater drum) accounted for an additional 25.4 percent. Gizzard shad, numerically dominant at this location, ranked fourth by weight (11.4 percent).

49. Species diversity at Leota ranged from 0.93 during April 1979 to 2.88 during June 1979 (Figure 8). Values at Leota always exceeded those for Cracraft, and exceeded those for Chicot Landing Dike Field during September 1980.

Chicot Landing Dike Field

50. A total of 42 species and $2339 \mathrm{fish}$ were captured during the two summer low-water collections at Chicot Landing Dike Field (Table 7). Thirty-eight species and 766 fish were collected during September 1979, and 33 species and 1573 fish during September 1980.

51. The family Cyprinidae (minnows and shiners) numerically dominated the catch at Chicot, accounting for over 57 percent of the total number of individuals (Table 7). Silverband and blacktail shiners comprised 27.4 percent and 13.1 percent, respectively. Three other cyprinids, river shiner, emerald shiner, and bullhead minnow, collectively accounted for an additional 17 percent. Gizzard shad constituted only 8.2 percent of the catch at Chicot. Sport-commercial species were also relatively less abundant at this location, making up only 16.2 percent. Blue catfish, bluegill, river carpsucker, freshwater drum, and channel catfish comprised the majority of the sport-commercial species, ranging in descending order from 3.8 percent to 1.8 percent.

52. By weight, blue catfish made up nearly 31 percent of the catch at Chicot Landing Dike Field, ranking second in September 1979 and first in 1980 (Table 8). River carpsucker and gizzard shad ranked second and third, respectively. Together these three species comprised over 62 percent of the total weight of fish. The 10 highest ranking species by weight made up over 93 percent (Table 8); approximately 70 percent was accounted for by species in the sport-commercial category.

53. Chicot Landing had the highest species diversity of all dike field locations during September 1979 (Figure 8). Diversity decreased during September 1980. 


\section{Dike field comparisons}

54. The ichthyofaunas of the dike fields were quite similar in terms of overall species occurrence, seasonal species composition, and relative abundance. The combined list for the three dike fields totaled 53 species. Forty-two of these species were recorded for Chicot, although it was sampled only twice; 45 and 46 species occurred at Cracraft and Leota, respectively.

55. Except during April, coefficient of community values for the Leota-Cracraft pair were high and consistent throughout the year (Table 9). The low April coefficient may have been due to sampling constraints imposed by the high spring water levels. Percentage similarity of these dike fields, however, declined steadily from April to November 1979, and was also relatively low during September 1980. This suggests that as river levels decline during the summer, the Leota and Lower Cracraft Dike Fields become sufficiently differentiated from each other to cause shifts in relative species abundances.

56. Gizzard shad was the most abundant species overall (Tables 3 , 5, and 7). Several cyprinids, principally river, blacktail, silverband, and emerald shiners, also comprised significant percentages of the overall dike field fauna. Blue, flathead, and channel catfishes were generally the most abundant sport-commercial species. Carp, river carpsucker, smallmouth buffalo, freshwater drum, and gizzard shad, together with the above three species of catfish, constituted most of the catch by weight in the dike fields. At two locations (Leota and Chicot), shortnose and longnose gar also accounted for a relatively high percentage.

57. The relative $\mathrm{C} / \mathrm{f}$ for the three dike fields varied widely across seasons and gear types (Figure 9). The $\mathrm{C} / \mathrm{f}$ for seining indicated higher densities of fish during September 1979 and generally lower densities during November 1979. Overall ranking of dike fields (high to low densities) was indicated as Chicot-Cracraft-Leota. Electroshocking $\mathrm{C} / \mathrm{f}$, opposite to that of seining, indicated very low fish densities during September 1979. High numbers of fish were found during September 1980, however. For electroshocking, dike field ranking was 


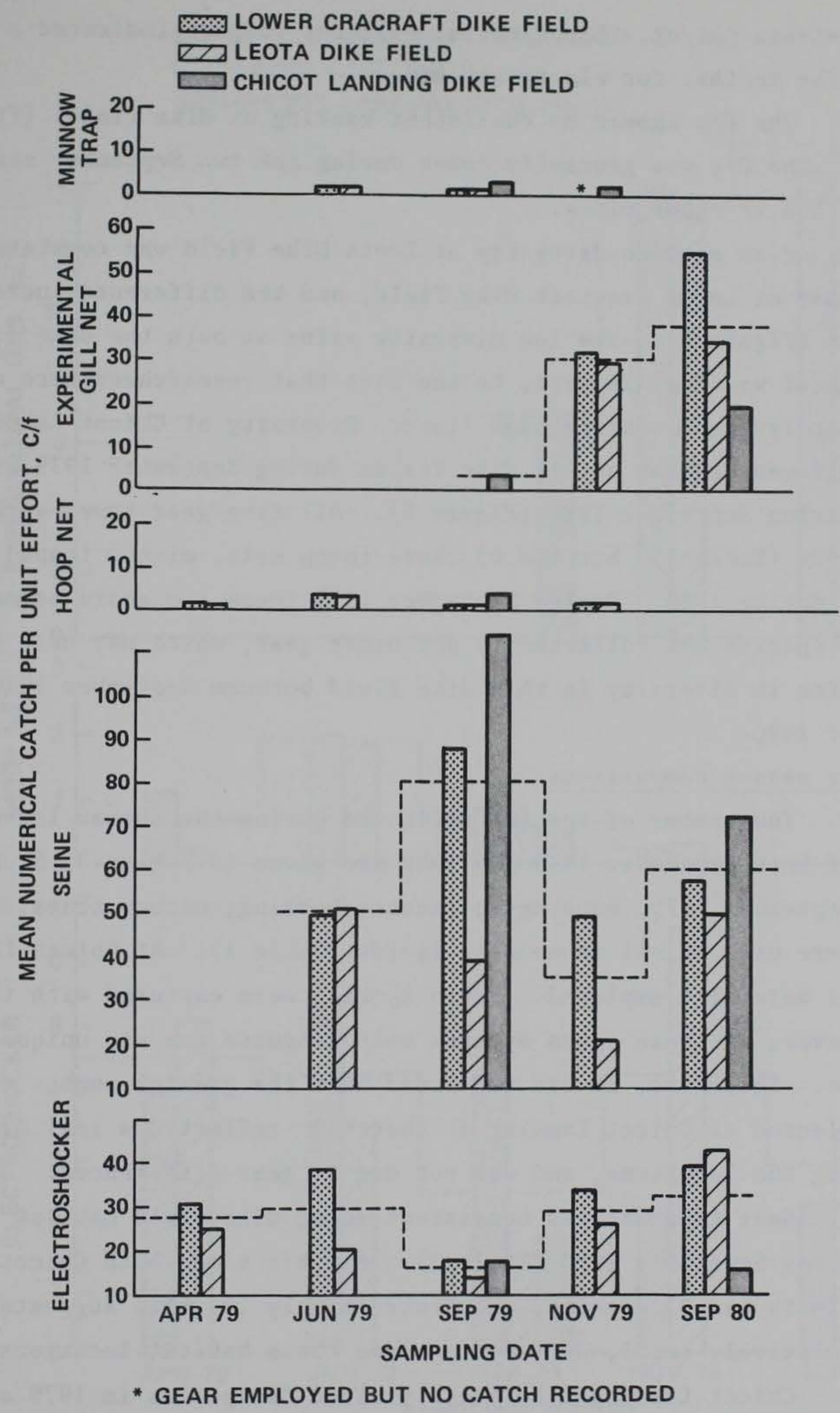

Figure 9. Mean $\mathrm{C} / \mathrm{f}$ by gear type for three Mississippi River dike fields. Dotted line indicates the mean of all dike fields at each sampling effort 
Cracraft-Leota-Chicot. Experimental gill net samples indicated a ranking similar to that for electroshocking.

58. The $\mathrm{C} / \mathrm{y}$ showed no consistent ranking of dike fields (Figure 10). The $\mathrm{C} / \mathrm{y}$ was generally lower during the two September sampling periods than at other times.

59. Fish species diversity at Leota Dike Field was consistently higher than at Lower Cracraft Dike Field, and the difference increased over time (Figure 8 ). The low diversity value at both the dike fields during April was due, in part, to the fact that researchers were unable to adequately sample during high flows. Diversity at Chicot Landing Dike Field was highest of all dike fields during September 1979 but declined during September 1980 (r'igure 8). All five gear types were used during 1979 (Table 1), but two of these (hoop nets, minnow traps) were not used during 1980. During September 1979 these two gears accounted for five species not collected by any other gear, which may help explain the decline in diversity in this dike field between September 1979 and September 1980 .

Low-water season comparisons

60. The number of species collected during the summer low-water period of both September 1979 and 1980 are given in Tables 3, 5, and 7 . During September 1979, hoop nets, electroshocking, minnow traps, and seines were used at all three dike fields (Table 1). At Chicot Landing, gill nets were also employed. Seven species were captured with the gill net; however, of these seven species only longnose gar was unique to the gear type. Therefore, it was concluded that the greater number of species collected at Chicot Landing at that time reflected a real difference among the locations, and was not due to gear differences.

61. Gear type use was consistent among dike field habitat locations during September 1980 (Table 1). At this time, both Chicot Landing and Leota had 33 species, and Cracraft only 28; this suggests a real, though relatively small, difference among these habitat locations.

62. Chicot Landing Dike Field yielded 38 species in 1979 and 33 in 1980. The differences may have been due to gear type use. Two additional gears, hoop nets and minnow traps, were used in 1979 that were 


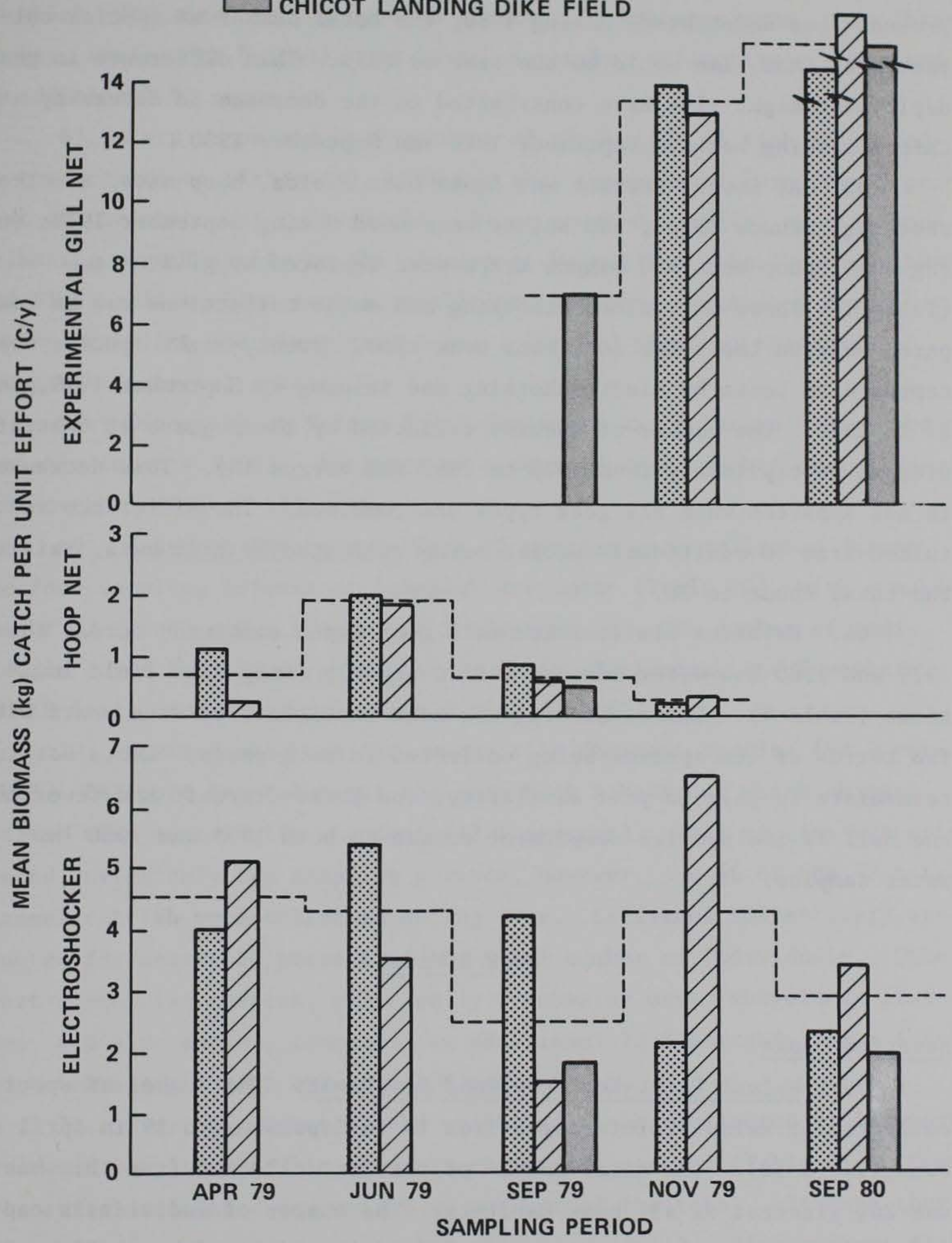

Figure 10. Mean $\mathrm{C} / \mathrm{y}$ by gear type for three Mississippi River dike fields. Minnow trap and seine data are not plotted due to the small weight of fish captured by these gears. Dotted line indicates the mean of all dike fields at each sampling ef fort 
not used in 1980. During 1979, these two gears accounted for five species not collected by other methods. If these species are assumed to be present (but undetected) during 1980, the total number of species collected at that time would be the same as 1979. This difference in gear deployment might also have contributed to the decrease in diversity at Chicot Landing between September 1979 and September 1980.

63. At Lower Cracraft and Leota Dike Fields, hoop nets, electroshocking, minnow traps, and seines were used during September 1979; during 1980, hoop nets and minnow traps were replaced by gill nets (Table 1). Thus, only electroshocking and seine collections can be compared between these two locations over time. Twenty-eight species were captured at Leota by electroshocking and seining in September 1979, and 27 in 1980. The number of species collected by these gears at Cracraft dropped precipitously from 1979 to 1980 (32 versus 18). This decrease is not apparent when all gear types are combined. The difference resulted from 10 additional species being collected by gill nets, raising the total count to 28 .

64. Relative similarities (all gear types combined) across the 1979 and 1980 low-water samples varied greatly among dike field locations (Table 9). Chicot Landing was most consistent between years with two thirds of its species being collected in both years. Leota was intermediate in year-to-year similarity, and Lower Cracraft had fewer than one half of its species complement common to both 1979 and 1980 lowwater samples.

\section{Bank Habitat}

$\underline{\text { Revetted banks }}$

65. Walnut Point-Kentucky Bend Revetment. The number of species collected at Walnut Point ranged from 11 in September to 19 in April and June (Table 10). The total number of species collected from this habitat was 26 , greatest of all bank habitats. The number of individuals captured during a sampling period ranged from 131 in September 1979 to 305 in November 1979 and totaled 860. 
66. Gizzard shad comprised 50.7 percent numerical abundance at Walnut Point. Sport-commercial species accounted for nearly 42 percent, of which catfishes made up over 18 percent. Freshwater drum, carp, blue sucker, smallmouth buffalo, and river carpsucker collectively comprised an additional 23 percent.

67. Carp comprised 20.7 percent of the weight of fish collected at this revetment (Table 11), although they represented less than 5 percent of the number of individuals. Other sport-commercial species contributing significantly to the biomass at Walnut Point included flathead and blue catfish, blue sucker, smallmouth buffalo, freshwater drum, channel catfish, and river carpsucker. Gizzard shad was the dominant nonsport-commercial species.

68. Diversity at Walnut Point Revetment was relatively high and variable (mean $=1.62$ ). Extremes of diversity were reached during June and November (Figure 11).

69. Lakeport Revetment. Only 16 species were collected during the four sampling efforts at Lakeport Revetment (Table 12), with a maximum of 12 (June) and a minimum of 5 (September). The number of individuals collected was very low during April, September, and November (16-19 fish), and relatively high during June (221).

70. Gizzard shad was the numerically dominant species (58.9 percent). Lakeport Revetment was the only bank habitat at which channel catfish were numerically abundant (17.1 percent). This species was collected during only two sampling periods, however, and 46 of the 47 total channel catfish were collected during June. Catfishes collectively accounted for nearly 24 percent of the total number of individuals. Other sport-commercial species, principally freshwater drum, shovelnose sturgeon, and blue sucker, comprised an additional 13.8 percent, for a total sport-commercial catch exceeding 38 percent.

71. Over 80 percent of the weight of fishes collected at Lakeport Revetment was attributable to sport-commercial species (Table 11). Channel catfish accounted for nearly 40 percent of the total, although they were abundant only during a single collection (June). Blue sucker, flathead catfish, shovelnose sturgeon, blue catfish, gizzard shad, and 


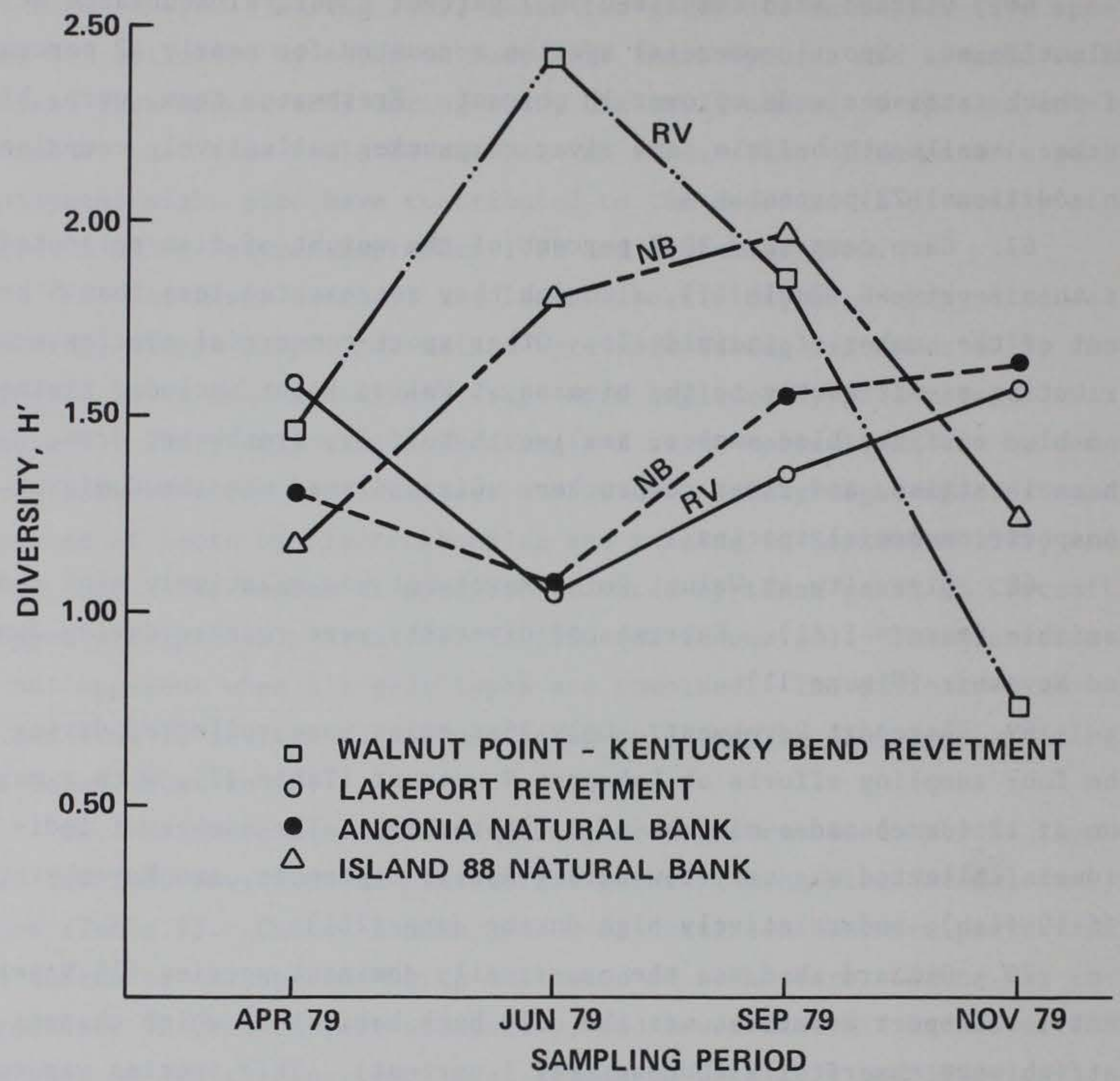

Figure 11. Species diversity for revetted (RV) and natural bank (NB) habitats in the Mississippi River

freshwater drum also contributed significantly to the biomass at this location.

72. Mean diversity at Lakeport Revetment was 1.40 . Diversities ranged from 1.07 to 1.59 (Figure 11).

Natural banks

73. Anconia Natural Bank. Twenty-two species of fish were collected from Anconia Natural Bank over the four sampling dates. From 6 to 11 species, and from 21 to 108 individuals, occurred at any single sampling effort (Table 13). Gizzard shad, threadfin shad, and skipjack 
herring comprised 71.5 percent of the total number of individuals. Just over one fourth (26.6 percent) of the fish were in the sport-commercial category. Catfishes, primarily flathead and blue, accounted for over 14 percent, and freshwater drum comprised 4.5 percent. The remaining 16 species were each represented by two or fewer individuals (less than 0.9 percent).

74. Sport-commercial species comprised over two thirds of the weight of fishes ( 68.4 percent) collected at Anconia Natural Bank (Table 11). Flathead catfish, bigmouth buffalo, blue sucker, blue catfish, and freshwater drum ranked first, and third through sixth in weight, respectively. Gizzard shad and skipjack herring ranked second and seventh, respectively, and together accounted for 24.6 percent by weight. The rank by weight of bigmouth buffalo in this habitat is somewhat misleading, however, as it represents only two individuals.

75. Species diversity at Anconia ranged from 1.08 during June to 1.64 in November (Figure 11). The mean diversity over all four sampling periods was 1.39 .

76. Island 88 Natural Bank. Twenty species of fish were represented in collections from Island 88 Natural Bank, with the number collected at any single sampling date ranging from 7 to 11 (Table 14). The number of individuals ranged from only 19 to 67 .

77. Gizzard shad was least dominant here of all bank habitats (42.7 percent). Sport-commercial species were very abundant, accounting for nearly one half ( 48.7 percent) of the total number of individuals. Freshwater drum, the three species of catfishes, bluegill, and white crappie comprised most of this category.

78. Seven sport-commercial species (Table 11) comprised 69.6 percent of the weight at Island 88. Flathead catfish and freshwater drum accounted for much of this total. Gizzard shad and two gar species constituted approximately 21 percent.

79. Diversity was considerably lower during April and November than during June and September (Figure 11), reflecting the trend in relative abundance of gizzard shad. Mean diversity for the four sampling periods was 1.55 . 
80. Comparisons of bank habitats. Thirty species of fish, totaling 1506 individuals, were collected from the four bank habitats. Four species (gizzard shad, flathead catfish, blue catfish, and freshwater drum) numerically dominated the catch in all bank habitats. These species accounted for 69.8 percent (Lakeport Revetment) to 80.1 percent (Anconia Natural Bank) of the total number of individuals. Gizzard shad was the single most abundant species, ranging in relative abundance from 42.7 to 62.0 percent. Flathead catfish, blue catfish, and freshwater drum ranged from 2.6 to 10.7 percent, 4.4 to 7.0 percent, and 4.0 to 17.3 percent, respectively. In addition to these species, channel catfish and shovelnose sturgeon were relatively abundant at Lakeport Revetment, and carp and smallmouth buffalo were common at Walnut Point Revetment. Blue sucker was moderately abundant in both revetted bank habitats. Skipjack herring and threadfin shad were relatively abundant at Anconia Natural Bank.

81. Over all bank habitats, sport-commercial species comprised most of the biomass. Species in this category comprised a greater proportion of the biomass in revetted bank habitats than in natural bank habitats, where shad and gar were relatively more important. Flathead catfish, gizzard shad, blue catfish, and freshwater drum contributed significantly to the biomass in all bank habitats, while carp, blue sucker, and bigmouth and smallmouth buffalo were important in three of the four bank habitats. Seven additional species contributed significantly to the weight of fish collected in only one or two habitats (Table 11).

82. Mean $\mathrm{C} / \mathrm{f}$ for the four bank habitats showed no consistent ranking (Figure 12). Seasonally, June values were highest overall and September values lowest. The $\mathrm{C} / \mathrm{f}$ at Walnut Point exceeded that at Lakeport at all sampling periods except June, when unusually large numbers of gizzard shad and channel catfish were collected at Lakeport. The relative C/f at Anconia Natural Bank and Island 88 Natural Bank was more variable. Mean $\mathrm{C} / \mathrm{f}$ for the two revetted banks combined exceeded that for the natural banks at all sampling periods except April.

83. Mean $\mathrm{C} / \mathrm{y}$ in revetted bank habitats was highest during June 

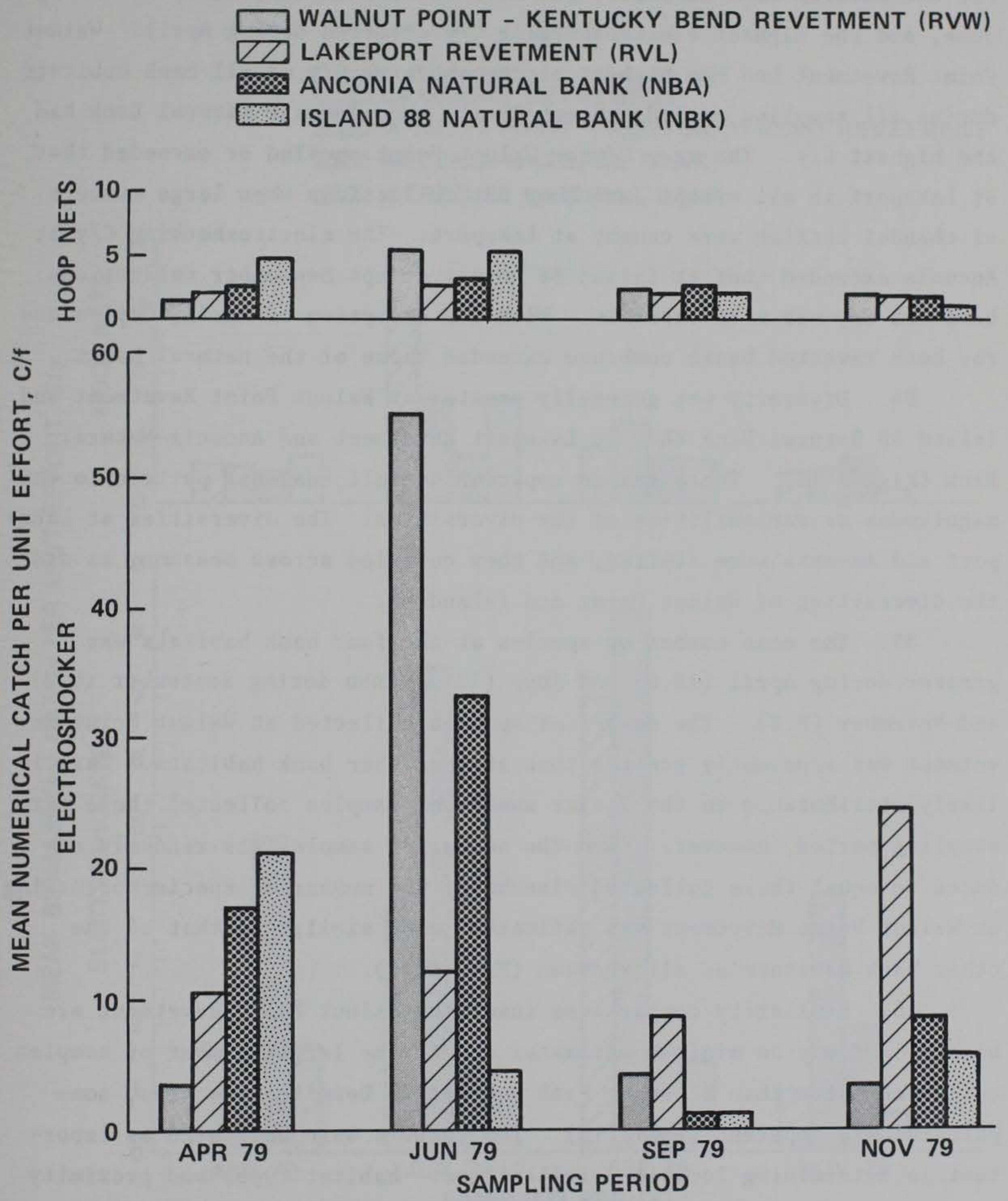

Figure 12. Mean $\mathrm{C} / \mathrm{f}$ for revetted and natural bank habitats in the Mississippi River 
and September for both hoop netting and electroshocking (Figure 13). For the natural bank habitats, the highest hoop net $\mathrm{C} / \mathrm{y}$ occurred during June, and the highest electroshocking $\mathrm{C} / \mathrm{y}$ occurred during April. Walnut Point Revetment had the highest electroshocking $\mathrm{C} / \mathrm{y}$ of all bank habitats during all sampling periods except April, when Anconia Natural Bank had the highest $\mathrm{C} / \mathrm{y}$. The mean $\mathrm{C} / \mathrm{y}$ at Walnut Point equaled or exceeded that at Lakeport in all except June hoop net collections when large numbers of channel catfish were caught at Lakeport. The electroshocking $\mathrm{C} / \mathrm{y}$ at Anconia exceeded that at Island 88 in all except September collections; hoop net $\mathrm{C} / \mathrm{y}$ was more variable. With the exception of April, C/y values for both revetted banks combined exceeded those of the natural banks.

84. Diversity was generally greater at Walnut Point Revetment and Island 88 Natural Bank than at Lakeport Revetment and Anconia Natural Bank (Figure 11). There was no apparent overall seasonal pattern to the magnitudes or variabilities of the diversities. The diversities at Lakeport and Anconia were similar, and they covaried across seasons, as did the diversities of Walnut Point and Island 88.

85. The mean number of species at the four bank habitats was greater during April (12.0) and June (13.2) than during September (8.2) and November (8.0). The number of species collected at Walnut Point Revetment was apparently greater than at the other bank habitats. This is likely attributable to the larger number of samples collected there per sampling period, however. When the number of samples was randomly reduced to equal those collected elsewhere, the number of species occurring at Walnut Point Revetment was estimated to be similar to that of the other bank habitats at all seasons (Figure 14).

86. Similarity comparisons involving Walnut Point Revetment are biased, and may be minimum estimates due to the larger number of samples collected there than at other bank habitats. Despite this bias, some patterns are apparent (Table 15). Two factors were suggested as important in determining location similarities: habitat type, and proximity. The fish populations of the two natural bank locations were very similar in species composition at all seasons (Table 15). With the exception of June, abundance composition values were also high. In contrast, the 
$Z$ LAKEPORT REVETMENT

$\square$ WALNUT POINT - KENTUCKY BEND REVETMENT

ANCONIA NATURAL BANK

ISLAND 88 NATURAL BANK

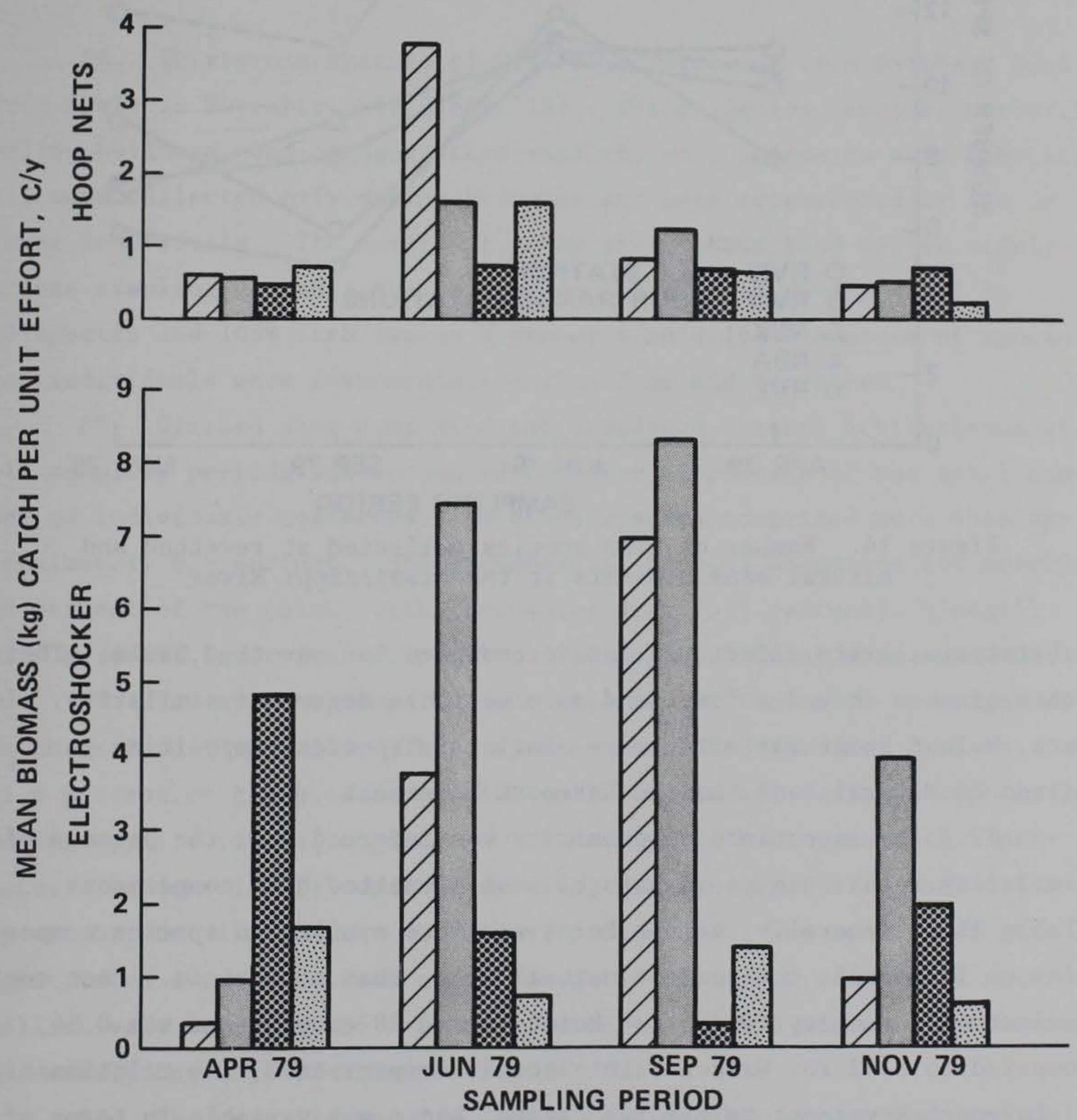

Figure 13. Mean $\mathrm{C} / \mathrm{y}$ for revetted and natural bank habitats in the Mississippi River 


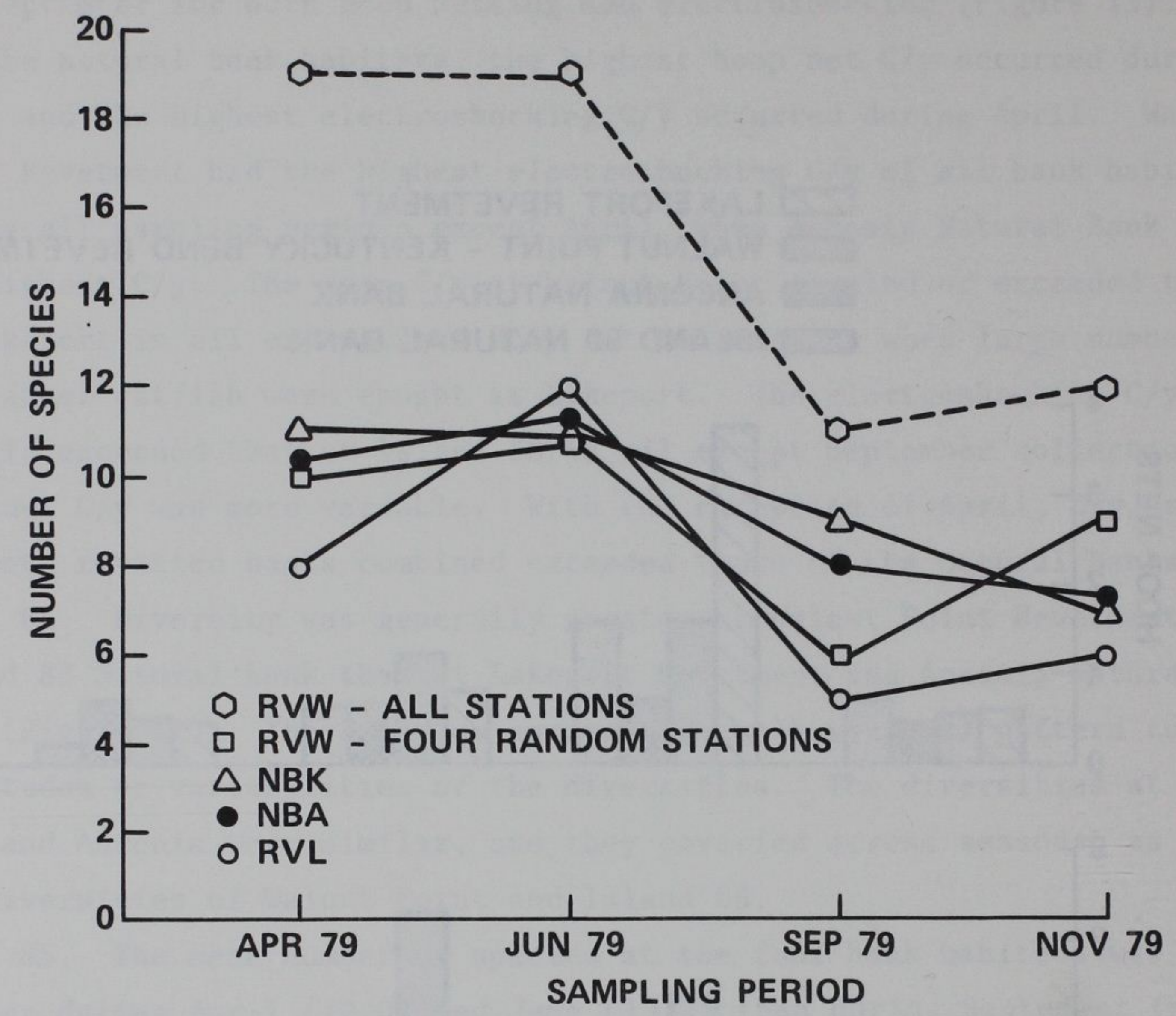

Figure 14. Number of fish species collected at revetted and natural bank habitats in the Mississippi River

habitat similarity effect was less pronounced for revetted banks. Their ichthyofaunas showed a lower and more variable degree of similarity. In fact, Walnut Point was often more similar in species composition to Island 88 Natural Bank than to Lakeport Revetment.

87. The importance of proximity was inferred from the pattern of similarity relationships in natural bank--revetted bank comparisons (Table 15). Generally, Walnut Point was more similar in species composition to Island 88, the nearest natural bank, than to Anconia. Mean coefficient of community for Walnut Point-Island 88 comparisons was 0.54 , compared to 0.42 for Walnut Point-Anconia comparisons. The relationship of Lakeport Revetment to the two natural banks was variable in terms of the coefficient of community. However, the percentage similarity index indicated that Lakeport was more similar, on the average, to Anconia. 
Mean percentage similarity for this pair was 0.48 , compared to 0.32 for Lakeport-Island 88. Overal1, less common species tended to occur in adjacent locations at a given sampling period (e.g. shortnose gar, American eel). For more abundant species, such as gizzard shad and freshwater drum, high or low numbers tended to be collected in adjacent areas.

\section{Abandoned Channel Habitat}

88. Thirty-one species of fish were collected from Matthews Bend from April to November 1979 (Table 16). Three species, spotted sucker, yellow bullhead, and orangespotted sunfish, were unique to this habitat. All were collected only during November and were represented by two or fewer individuals. The numerical catch at Matthews Bend varied widely across sampling periods, from 7 species and $33 \mathrm{fish}$ during April to 28 species and 1059 fish during November (Table 16). Numbers of species and individuals were intermediate during June and September.

89. Gizzard shad dominated the abandoned channel ichthyofauna at all sampling periods and accounted for over 62 percent of the total number of individuals collected. No other species comprised more than approximately 6.5 percent. Sport-commercial species accounted for nearly 20 percent of the catch, with freshwater drum (5.1 percent), bluegill (3.7 percent), and river carpsucker (2.4 percent) being most abundant.

90. Ten species comprised the majority of the catch by weight at Matthews Bend (Table 17). These species accounted for from 81.9 to 91.6 percent of the biomass of fish collected in all months except April. During April a single longnose gar of nearly 30 lb comprised 65.5 percent. The numerically dominant species, gizzard shad, also ranked first by weight, but its dominance was less pronounced. Two species of gar constituted over 19 percent of the weight. Six sport-commercial species collectively comprised 36.4 percent, with carp ( 16.3 percent) accounting for nearly one half of this total.

91. The mean $\mathrm{C} / \mathrm{f}$ and $\mathrm{C} / \mathrm{y}$ varied considerably across sampling periods (Figure 15). For both gears, $\mathrm{C} / \mathrm{f}$ and $\mathrm{C} / \mathrm{y}$ were lowest during April. Gill net C/f peaked during June at $71.3 \mathrm{fish}$ per $24-\mathrm{hr}$ set, double that 


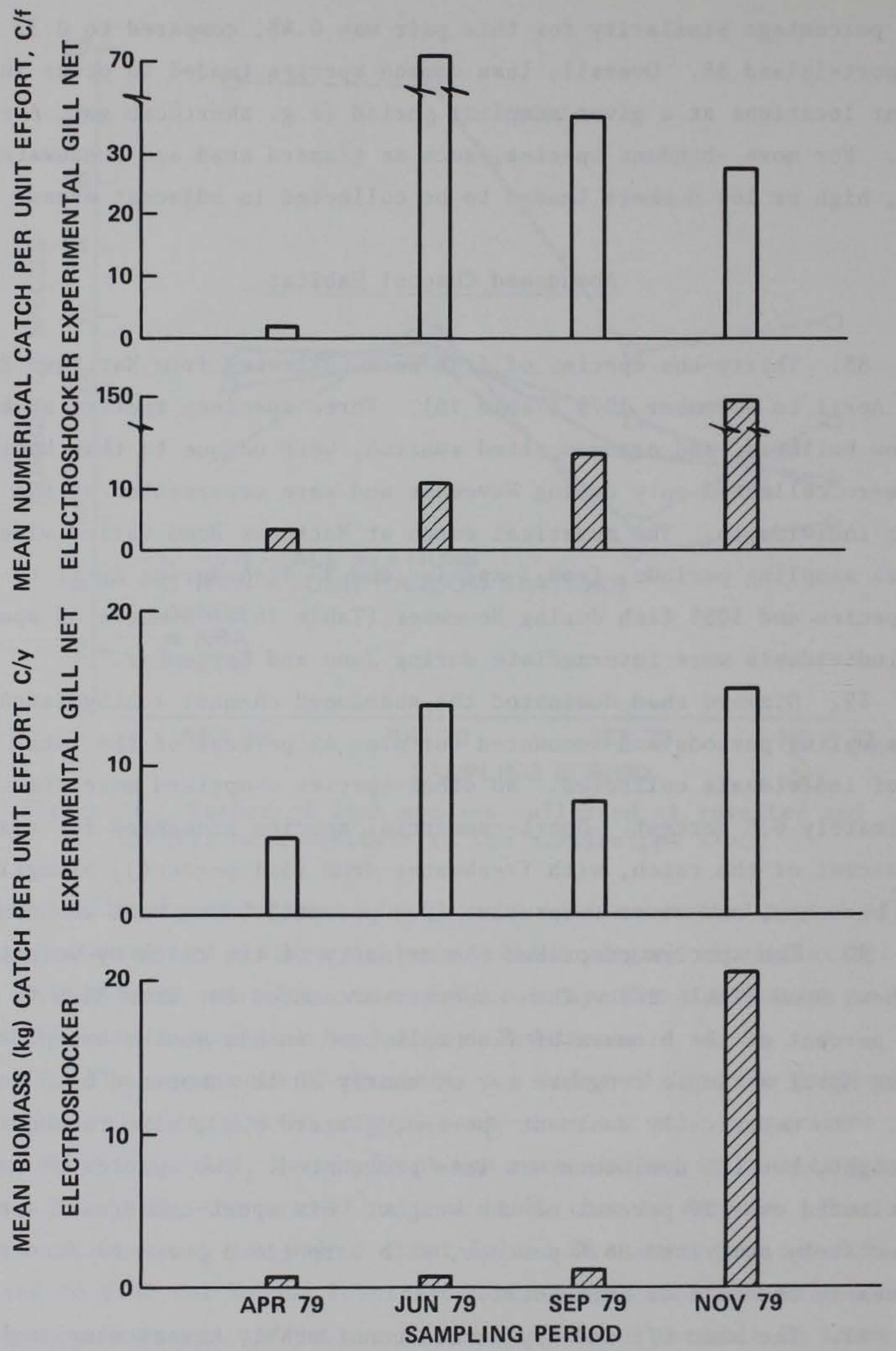

Figure 15. Mean $\mathrm{C} / \mathrm{f}$ and $\mathrm{C} / \mathrm{y}$ for the abandoned channel habitat in the Mississippi River 
of any other month. The $\mathrm{C} / \mathrm{y}$ was highest during November, however, indicating that fish collected at this time were relatively large. In contrast to gill net values, electroshocking $\mathrm{C} / \mathrm{f}$ and $\mathrm{C} / \mathrm{y}$ were significantly correlated $(\mathrm{r}>0.99, \mathrm{n}=4)$. Values increased slowly from April through September, then rose dramatically in November (Figure 15).

92. Species diversity increased steadily at Matthews Bend during the study. April diversity was lowest (0.97) and November the highest (1.68). The increase in diversity from September (1.58) to November was relatively small despite a near doubling of the number of species collected (15 to 28). This suggests that the diversity during November may be near the yearly maximum for this habitat.

\section{Length Frequencies}

Gizzard shad

93. Length frequencies of gizzard shad were similar in all habitats during April (Figure 16). At least three age classes (I-III) were apparent in all habitats except Lakeport Revetment, where the catch for this species was almost always low. Ages I-III fish averaged approximately 140,220 , and $275 \mathrm{~mm}$, respectively.

94. By June, the mean length of Age I fish had increased by about 30 to $40 \mathrm{~mm}$. This age group dominated gizzard shad populations in all habitats except Leota Dike Field and, to a lesser extent, Matthews Bend. older fish were nearly absent from bank habitats, but were common in the dike fields and the abandoned channel. During June, Age 0 fish (approximately 40 to 60 days old at this time) were collected only at Lower Cracraft Dike Field and Leota Dike Field. However, seining, an effective method of capturing juvenile fishes, was conducted only in these habitats, and this may have accounted for the failure to collect them in other habitats.

95. During September 1979, gizzard shad were virtually absent from bank habitats (Figure 16). Increasing numbers of Age 0 fish (approximately 50 to $100 \mathrm{~mm}$ total length (TL)) occurred in the three dike fields. Older fish continued to comprise the majority of this species in Matthews Bend. 


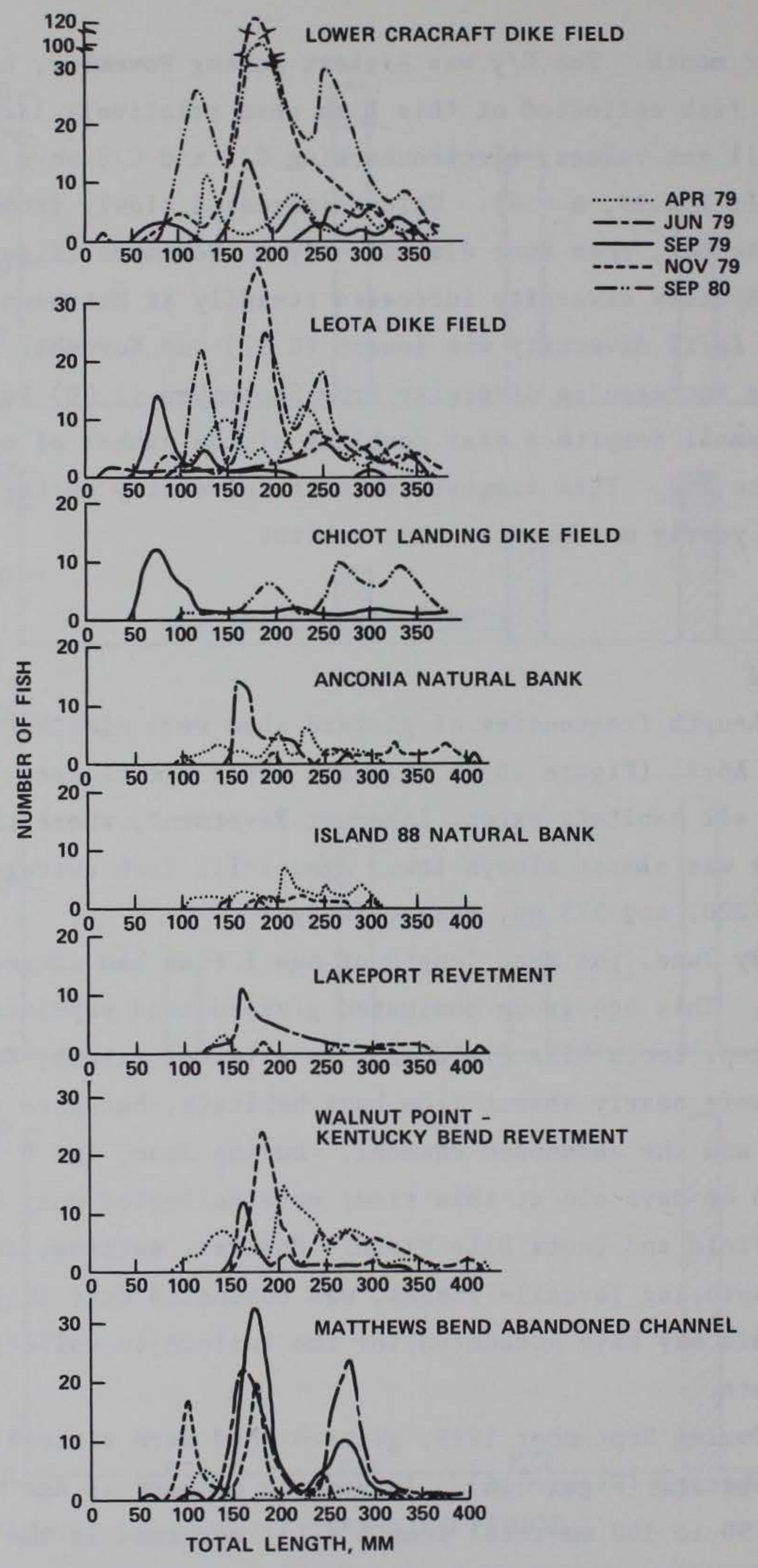

Figure 16. Length frequency of gizzard shad from the Mississippi River 
96. The catch of gizzard shad during November was still low at three of the four bank habitats. At Walnut Point Revetment, at least three year classes (Ages I to III) were again apparent (Figure 16), with Age I fish predominating (ca. 150 to $200 \mathrm{~mm}$ TL). No Age 0 fish were collected here, and only a single individual was taken at the four bank habitats combined. A similar size distribution occurred at Cracraft and Leota Dike Fields, with the exception that some Age 0 fish were collected in these habitats. Age 0 gizzard shad were relatively abundant only in Matthews Bend.

97. Comparisons of gizzard shad length frequencies from the three dike fields during September 1979 and September 1980 (low-water samples) show some differences. Age 0 fish from 1980 collections at Cracraft and Leota averaged nearly $40 \mathrm{~mm}$ TL longer than the same age group in 1979 (Figure 16). This may have been caused by a relatively later spawn in 1979 , or by relatively better conditions for growth during the summer of 1980. Also, four distinct size classes, corresponding to Ages 0 to III, were apparent during September 1980 but not during September 1979.

98. Length frequencies of gizzard shad at Chicot Landing Dike Field were generally similar to those at Cracraft and Leota. However, during September 1980, almost no Age 0 fish were collected at Chicot (Figure 16).

\section{Freshwater drum}

99. Numbers of freshwater drum were sufficient to make length frequency comparisons among habitats at only some sampling periods. During June, the distribution of sizes in dike field habitats was relatively uniform (Figure 17). Age 0 fish were missing from June collections at Walnut Point Revetment and Matthews Bend, however, and these habitats were dominated by fish of a single size class (225 to $325 \mathrm{~mm} \mathrm{TL}$ ).

100. During September 1979, Age 0 freshwater drum were collected only at Chicot Landing Dike Field (Figure 17); other habitats had predominantly Age I fish (150 to $250 \mathrm{~mm}$ TL). A similar size distribution occurred during November except that drum in the abandoned channel showed a smaller range of sizes. 

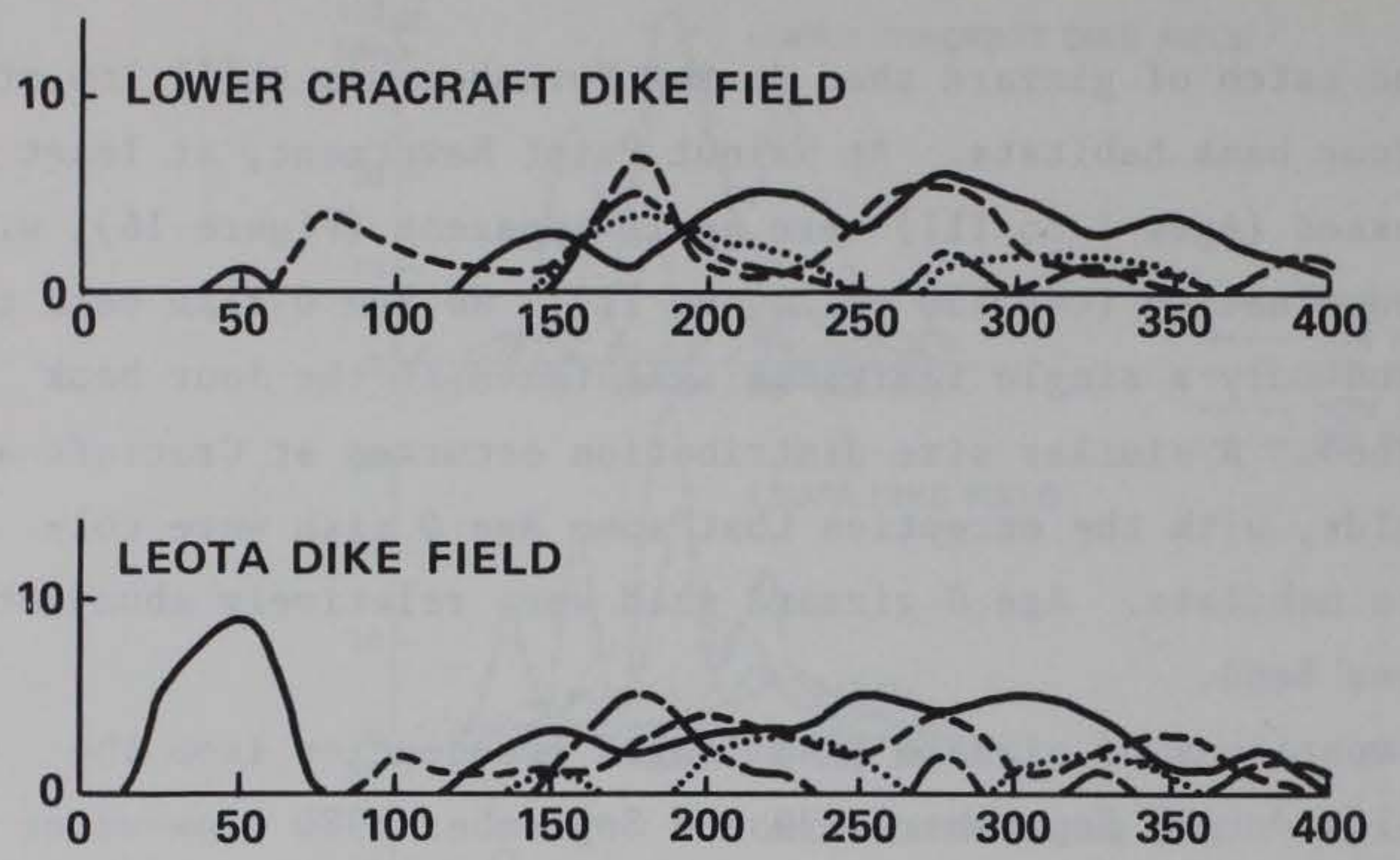

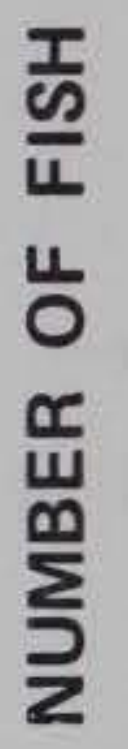
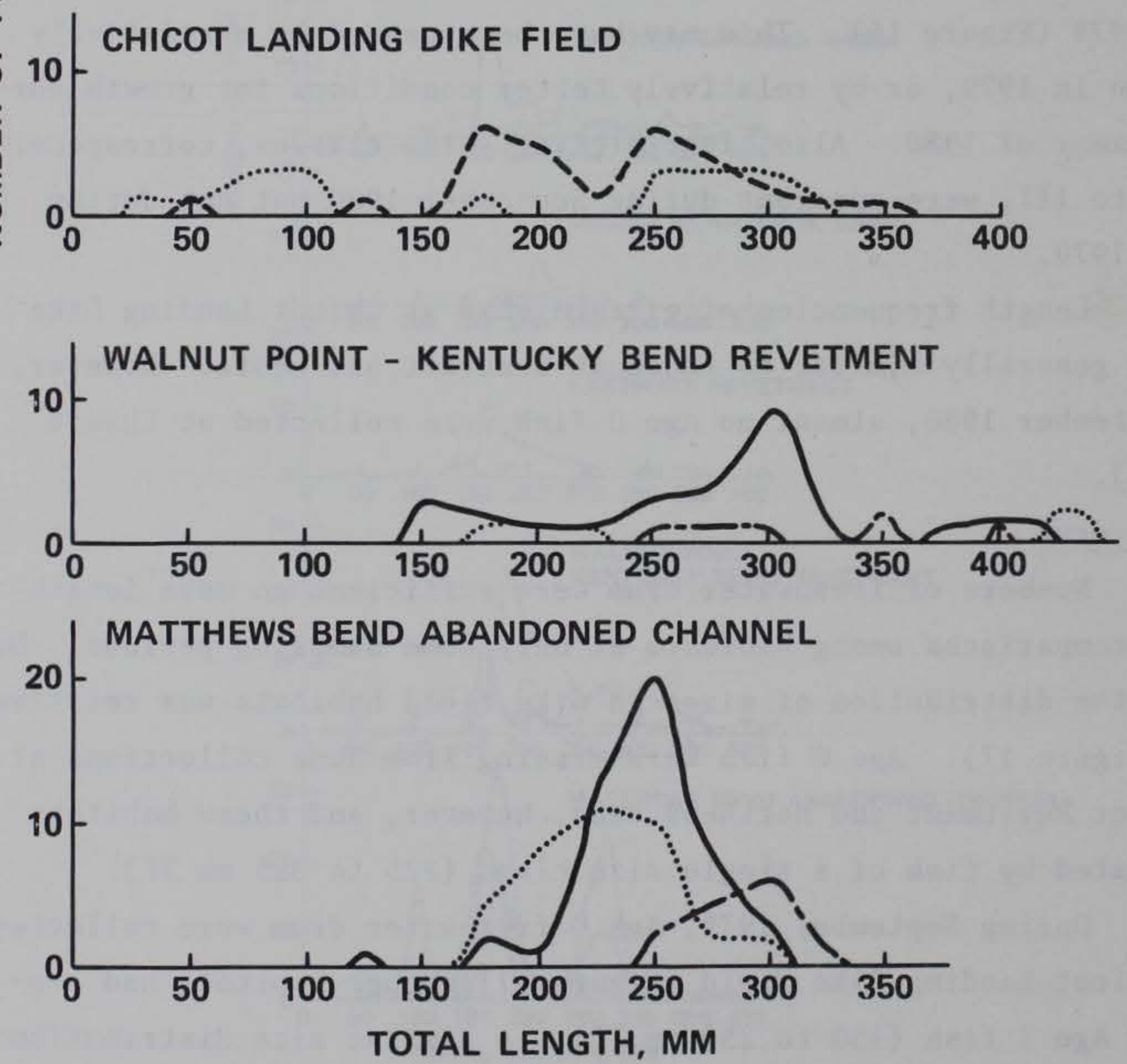

Figure 17. Length frequency of freshwater drum from the Mississippi River 
101. Distribution of freshwater drum size classes in September 1980 indicated increased numbers of Age 0 fish at Lower Cracraft and Leota Dike Fields over those of the previous September. Numbers of Age 0 fish were reduced at Chicot Landing, however.

\section{$\underline{\text { River shiner }}$}

102. This species was collected only from the three dike fields; in this habitat, however, they were one of the most abundant species. The inability to use seines may have accounted for their absence in collections made in other habitats as well as the April, high-water sampling period in the dike field habitats.

103. The size distribution of river shiners at Cracraft and Leota during June were somewhat different (Figure 18). In general, slightly larger fish occurred at Cracraft $(\bar{x} \approx 60 \mathrm{~mm}$ TL $)$ than at Leota $(\overline{\mathrm{x}} \approx 48 \mathrm{~mm}$ TL). Also, at Leota two size groups were abundant, possibly corresponding to early and late spawns during the summer of 1978 .

104. During September 1979, two distinct sizes of river shiners occurred in all three dike fields (Figure 18). Fish of approximately 25 to $50 \mathrm{~mm}$ TL undoubtedly represented Age 0 individuals; fish from 60 to $85 \mathrm{~mm}$ TL were older, probably mostly Age I. Between June and September, these Age I fish were indicated to have grown by about $10 \mathrm{~mm} \mathrm{TL}$.

105. Both size classes of river shiners were still identifiable during November 1979. As would be expected, mean lengths of these classes had increased by about 10 to $15 \mathrm{~mm}$ since September.

106. Length frequencies of river shiners collected during September 1980, in contrast to September 1979, indicated a population consisting almost entirely of Age 0 fish (Figure 18). This suggested that a large postspawn or overwinter mortality of older shiners may have occurred.

\section{Channel catfish}

107. Channel catfish were collected in sizes ranging from approximately 25 to $650 \mathrm{~mm}$. During April, June, and November 1979, all fish were Age I and older (TL > approximately $200 \mathrm{~mm}$ ), and the range of sizes was similar in all habitats (Table 18). Fish from revetted banks averaged slightly longer than those from other habitats, however. 


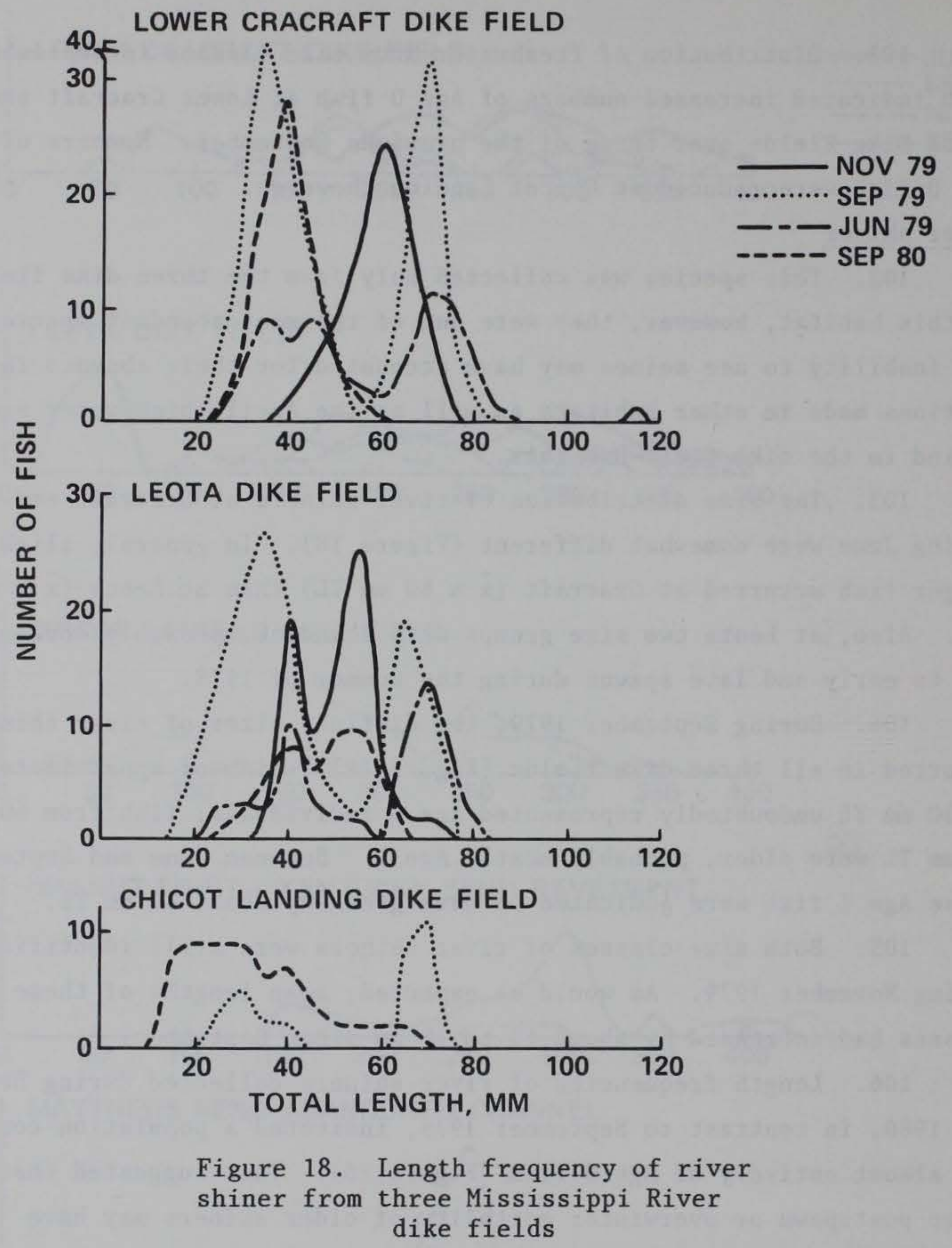

108. Young-of-year fish (Age 0) were collected only during the two September samples. In 1979, Age 0 individuals comprised most of the channel catfish captured (Figure 19). Most of these fish were found at Lower Cracraft and Chicot Landing Dike Fields. In contrast, in 1980 few Age 0 channel catfish were collected. 

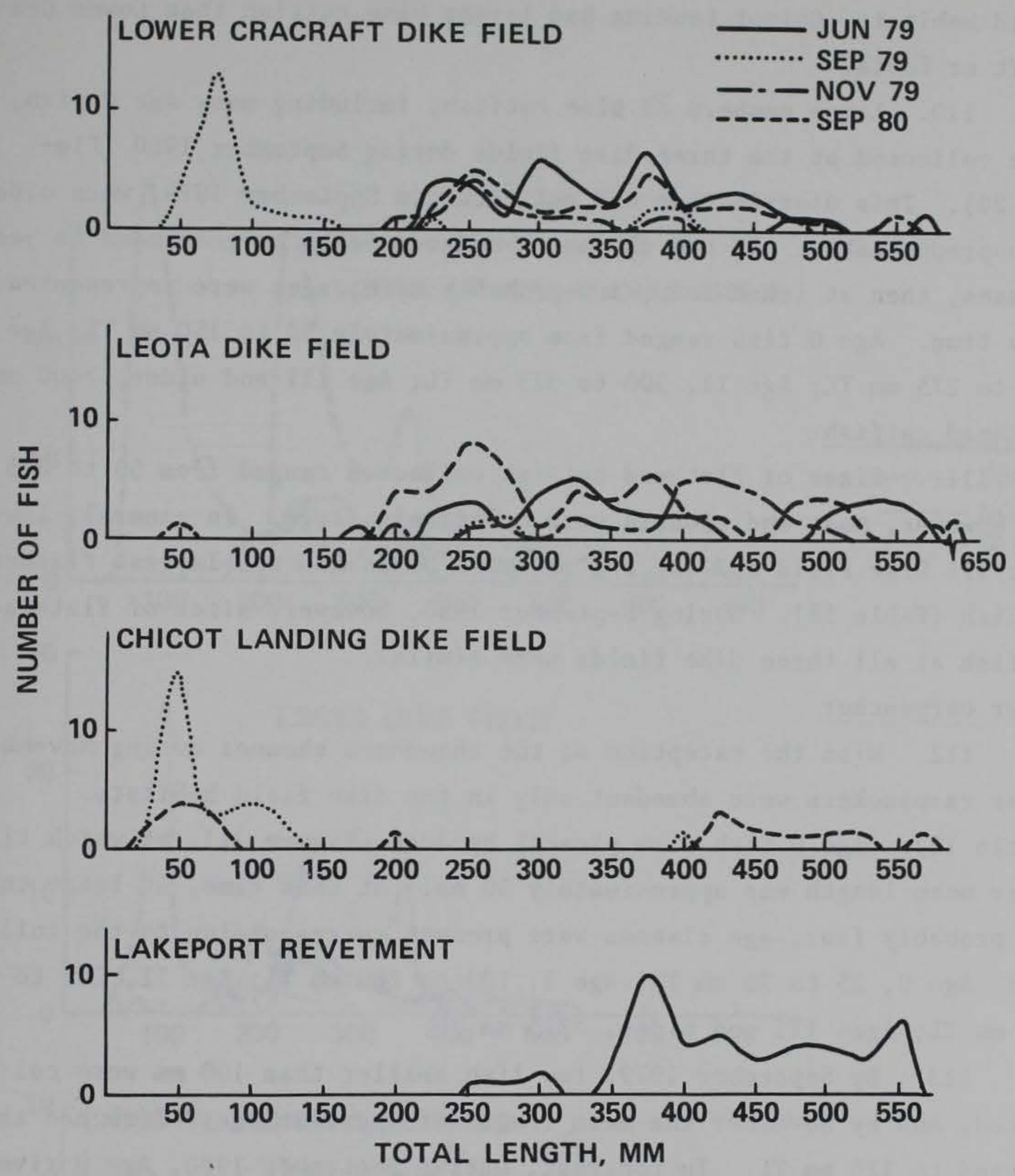

Figure 19. Length frequency of channel catfish from the Mississippi River

\section{Blue catfish}

109. Blue catfish ranged from approximately 50 to $725 \mathrm{~mm} \mathrm{TL}$ (Table 18). Size ranges and mean sizes varied considerably across seasons and habitats. During June, all habitats had blue catfish of similar sizes. In September and November 1979, fish from Walnut Point Revetment averaged considerably larger than those from other habitats. Of the dike 
field habitats, Chicot Landing had larger blue catfish than Lower Cracraft or Leota.

110. Large numbers of blue catfish, including many Age 0 fish, were collected at the three dike fields during September 1980 (Figure 20). This distribution did not occur in September 1979, when older fish predominated. If the obvious abundance peaks corresponded to year classes, then at least four, and probably more, ages were represented at this time. Age 0 fish ranged from approximately 50 to $150 \mathrm{~mm} \mathrm{TL}$; Age I, 175 to $275 \mathrm{~mm} \mathrm{TL}$; Age II, 300 to $375 \mathrm{~mm}$ TL; Age III and older, $>400 \mathrm{~mm}$. Flathead catfish

111. Sizes of flathead catfish collected ranged from 50 to $875 \mathrm{~mm}$ TL; however, most individuals were relatively large. In general, Lower Cracraft Dike Field and the two revetted banks had the largest flathead catfish (Table 18). During September 1980, however, sizes of flathead catfish at all three dike fields were similar.

\section{River carpsucker}

112. With the exception of the abandoned channel during November, river carpsuckers were abundant only in the dike field habitats (Table 18). Age 0 fish were present by June (Figure 21), at which time their mean length was approximately $50 \mathrm{~mm}$. At this time, at least three, and probably four, age classes were present corresponding to the following: Age 0, 25 to $75 \mathrm{~mm} \mathrm{TL}$; Age I, 100 to $200 \mathrm{~mm} \mathrm{TL}$; Age II, 225 to $350 \mathrm{~mm}$ TL; Ages III and older, >375 mm TL.

113. By September 1979 , few fish smaller than $100 \mathrm{~mm}$ were collected, and by November the mean length of apparent Age 0 fish had increased to $175 \mathrm{~mm}$ TL. In contrast, during September 1980, Age 0 river carpsuckers in the $25-$ to $125-\mathrm{mm}$ length group were relatively abundant.

\section{Condition Factors}

\section{Freshwater drum}

114. Mean condition factors ranged from 0.99 (Anconia Natural Bank, September 1979) to 1.52 (Island 88 Natural Bank, June 1979). overall, condition factor average was 1.22 . Values were highest in 


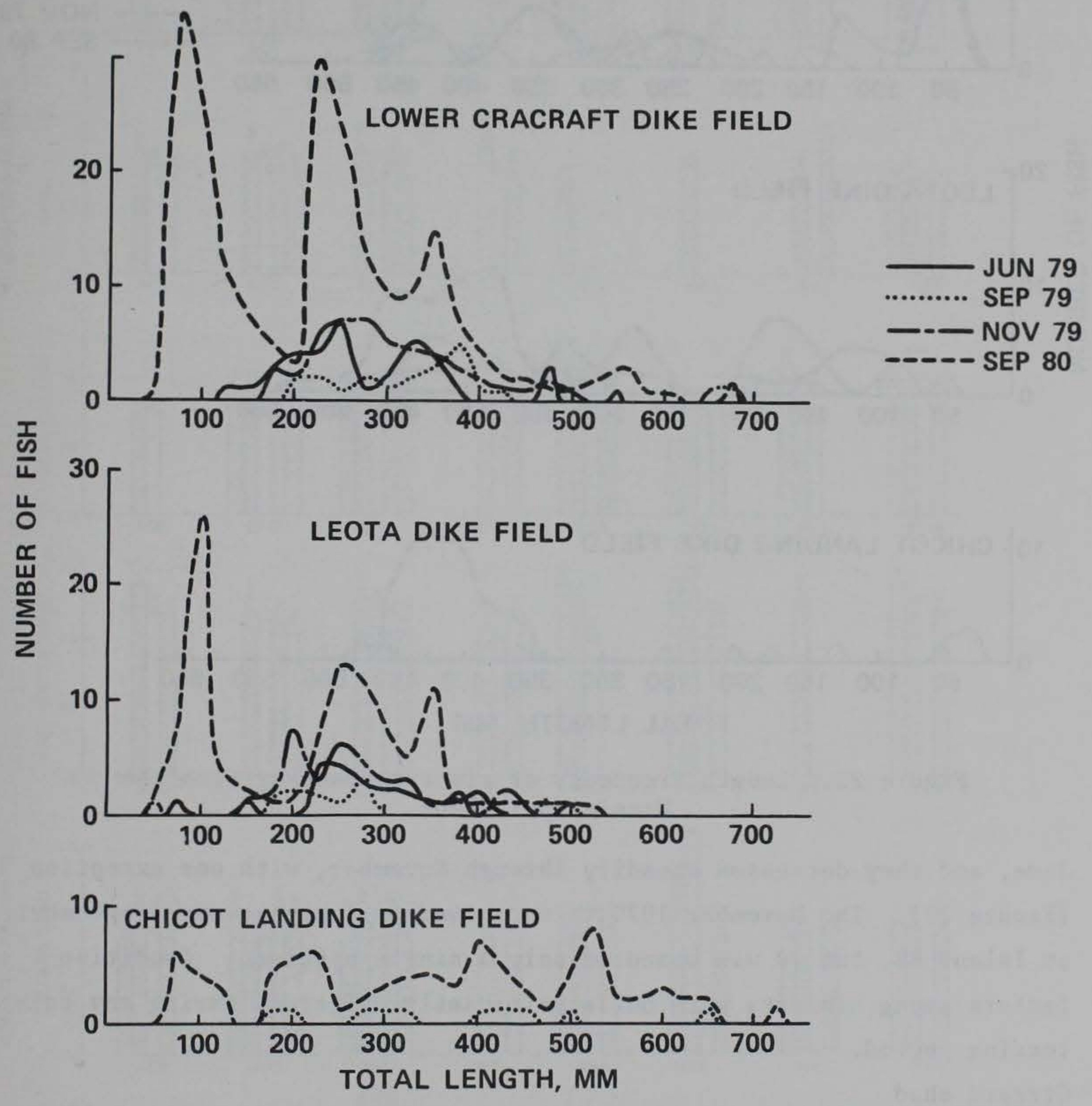

Figure 20. Length frequency of blue catfish from the Mississippi River 

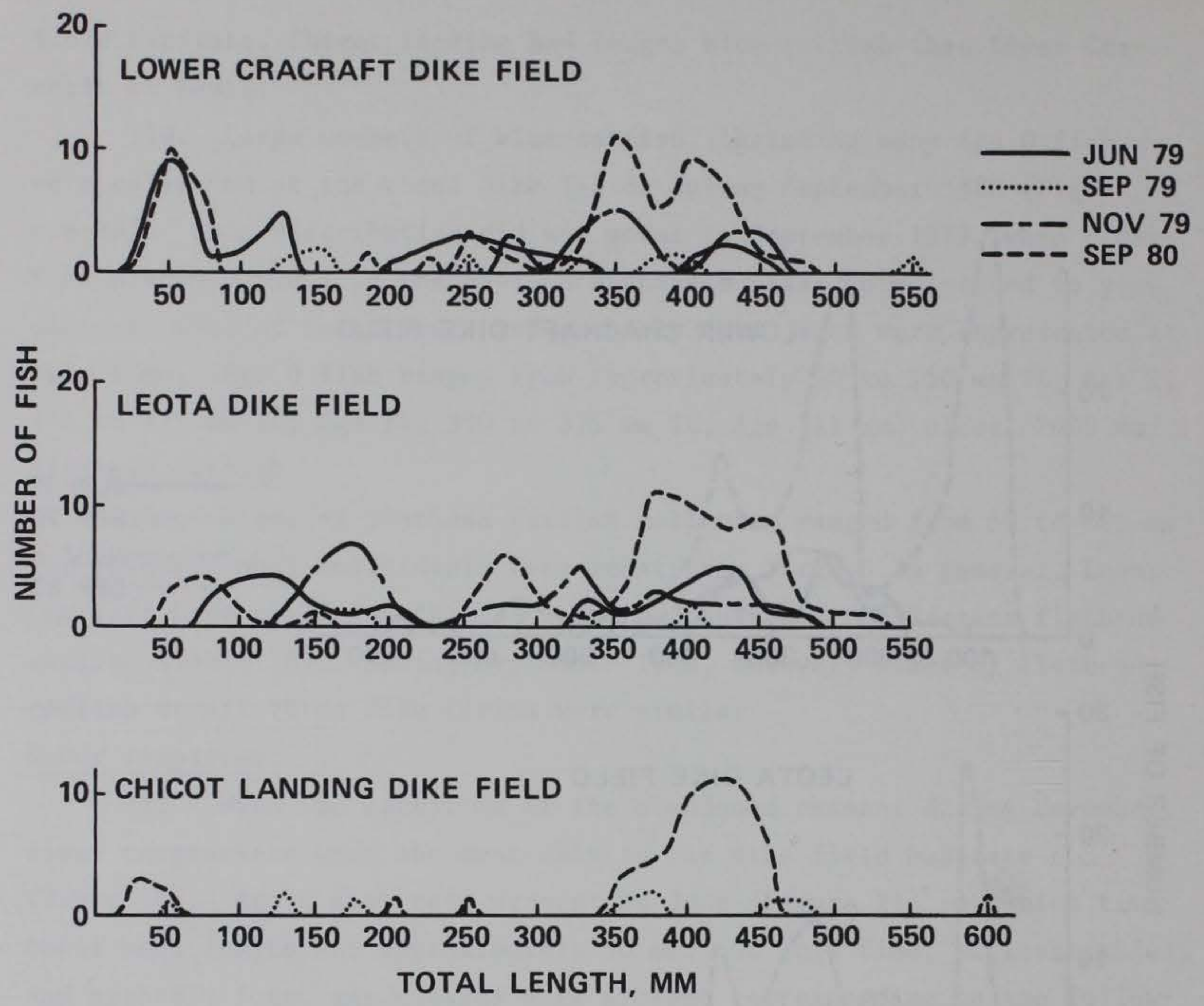

Figure 21. Length frequency of river carpsucker from the Mississippi River

June, and they decreased steadily through November, with one exception (Figure 22). The November 1979 value showed an increase over September at Island 88 , but it was based on only a single specimen. Condition factors among habitats were not significantly different during any collecting period.

Gizzard shad

115. Mean condition factors of gizzard shad ranged from 0.83 to 1.10 (Figure 22), and showed no obvious differences among habitats or seasons. The June value for gizzard shad at Island 88 is obviously incorrect, as the condition factor for one of the two specimens was considerably above any other published value. The condition factor for 

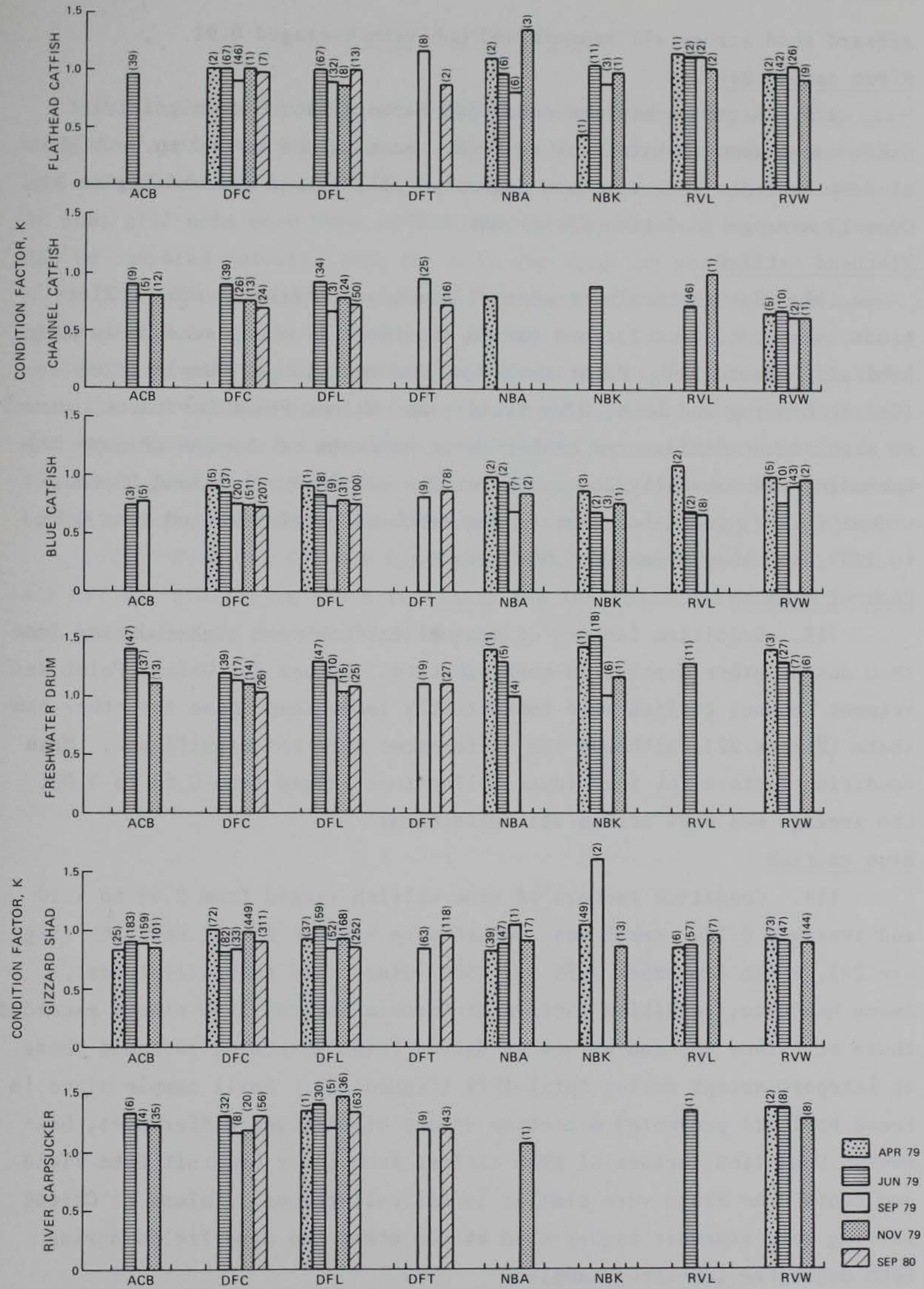

Figure 22. Condition factors for six species of fish from the Mississippi River 
gizzard shad across all seasons and habitats averaged 0.91 . River carpsucker

116. River carpsucker condition factors showed no significant differences among habitats or seasons. June values tended to be highest at most habitats, however, and September 1979 values lowest (Figure 22). Overall average condition factor was 1.27 .

\section{Flathead catfish}

117. Due to the low number of flathead catfish in some collections, mean condition factors varied considerably among seasons in many habitats (Figure 22). Habitats having somewhat larger sample sizes (Chicot Landing and Leota Dike Fields, and Walnut Point Revetment) showed no significant differences either among habitats or seasons (Figure 22). Excluding the unusually low value for the single April Island 88 individual ( 0.46$)$, condition factors for flathead catfish ranged from 0.85 to 1.37 , and they averaged 1.00 overall.

\section{Channel catfish}

118. Condition factors of channel catfish were higher during June than during other months, in most habitats. Values for Walnut Point Revetment channel catfish were consistently lower than those for other habitats (Figure 22), although the differences were not significant. Mean condition factors for individual collections ranged from 0.63 to 1.03 ; the average was 0.84 across all collections.

Blue catfish

119. Condition factors of blue catfish ranged from 0.63 to 1.10 and averaged 0.78. April mean values were highest in all habitats (Figure 22), while September 1979 and 1980 values were generally lowest. Among habitats, condition factors at Anconia Natural Bank always exceeded those at Island 88 , and values at Walnut Point Revetment exceeded those at Lakeport except during April 1979 (Figure 22). Small sample sizes in these habitats prevented detection of any significant differences, however. Condition factors of blue catfish from Lower Cracraft Dike Field and Leota Dike Field were similar in all collections. Values at Chicot Landing were somewhat higher than at the other two dike fields during both September low-water samples. 


\section{Catch per Unit Effort}

120. Since the units of effort for electroshocking and hoop netting were approximately equal in all four habitats, the relative catch per unit effort $(\mathrm{C} / \mathrm{f}, \mathrm{C} / \mathrm{y})$ can be used to compare them. One exception is that gill nets were used in Matthews Bend instead of hoop nets, and can be compared for this gear for only one sampling period.

121. Electroshocking $\mathrm{C} / \mathrm{f}$ and $\mathrm{C} / \mathrm{y}$ varied considerably from sampling period to sampling period in all habitats. Averaged across all collections, dike fields and revetted banks had higher $\mathrm{C} / \mathrm{f}$ and $\mathrm{C} / \mathrm{y}$ values than did natural banks and the abandoned channel. The difference was approximately 1.5 times greater for the $\mathrm{C} / \mathrm{f}$, and ranged from 2.5 to 4.0 times greater for the $\mathrm{C} / \mathrm{y}$. These averages do not include the exceptionally high November 1979 Matthews Bend catch, which may be atypical.

122. Hoop net $\mathrm{C} / \mathrm{f}$ and $\mathrm{C} / \mathrm{y}$ differed little among habitats. Gill net $\mathrm{C} / \mathrm{f}$ was similar in the dike fields and the abandoned channel, but $\mathrm{C} / \mathrm{y}$ was higher in the abandoned channel. 
123. Since the early 1900 's aquatic habitats on the Mississippi River have been altered by the construction of levees, dikes, and revetments, and by dredging. In the unimpounded Middle and Lower Mississippi River, side channels and other extra-channel habitats are being elevated relative to the main channel (Rasmussen 1979). In conjunction with high sedimentation rates, this is steadily reducing the river to predominantly main channel and main channel border habitats (Rasmussen 1979), which are less productive than extra-channel habitats (Barnickol and Starrett 1951; Pflieger 1971; Schramm and Lewis 1974).

124. Within the "reduced" river, aquatic habitats are also created by some modification activities. Some of these habitats, particularly dike fields, may at least partly replace lost habitats. Yet little information is available for comparing the relative merits of Lower Mississippi River habitats.

\section{Comparisons Among Habitats}

125. Comparisons among the four habitats investigated in this study are accurate only assuming that the gear types used in each habitat adequately sampled the species occurring there (Green 1979). This assumption was probably not strictly met (see Hocutt and Stauffer 1980) in this study. Nevertheless, it is evident that the habitats differ with respect to the ichthyofaunas they support. Dike fields, for example, harbored considerably more species than the other habitats. For many species, dike fields appeared to provide suitable habitat for many life history stages, from larvae (Schramm and Pennington 1980) to large adults. Age 0 fish were collected almost exclusively in the dike fields. Since most of these fish were collected in seines; the possibility that young fish also use the bank and the abandoned channel habitats cannot be dismissed. However, the occurrence of Age 0 fish of so many species indicates the importance of the dike fields as nursery areas. The progressive increase in the mean size of all age groups from June to 
November 1979 also indicates that many species utilize this habitat continuously during much of their life.

126. The diversity of fishes collected from the dike fields was undoubtedly attributable to the variety of microhabitats available. In particular, dike fields offer a wide range of depths, currents, and substrates, which have been shown to be important habitat components affecting fish distributions (Baker and Ross 1981; Gorman and Karr 1978; Harrell 1978; and Sheldon 1980).

127. Revetted and natural banks supported similar fish species overall. These habitats differed considerably in the percentage comprised by the various species, however. Burress, Krieger, and Pennington (1982) and Kallemeyn and Novotny (1977) found this also to be true on the Missouri River. In this study, revetted bank habitats supported the highest percentage, by weight, of sport-commercial fish. Sportcommercial species are generally large, and they may better withstand the higher currents found on revetted banks. Biases of the gear in favor of capturing larger fishes in high current areas may also have been a factor.

128. The relative abundances of many species collected from the abandoned channel were markedly different from those of other habitats. The abundance and weight of sport-commercial species, in particular, was very low in this habitat. Much higher sport-commerical fish percentages were found in apparently similar habitats by Robinson (1972).

129. Despite the differences in number of species, $C / f$ and $C / y$ were not, on the average, greater in the dike fields than in other habitats. Dike fields and revetted banks had higher values overall for electroshocking than natural banks and the abandoned channel; however, values for all habitats were variable across river stages.

130. Fish populations were less distinct during relatively highwater periods (April, and to some extent June) than during low-water periods (September and November). This is probably attributable to a decrease in habitat distinctness, and to increased movement of fishes in response to increasing spring water temperature and flow rate. The inability to seine in the dike fields during April undoubtedly also 
contributed to their relative lack of distinctness at this time.

\section{Comparison with Previous Studies}

\section{Species composition}

131. From a taxonomic standpoint, the ichthyofauna of the unimpounded Middle and Lower Mississippi River is reasonably well established. Ecologically, however, information on its fish assemblages is limited (NUS Corporation 1974). Nearly all data that are available have been collected within the past 15 years.

132. The Federal Water Pollution Control Administration (1969) made fish collections at many Lower Mississippi River sites following endrin pollution. Most of these collections were made with coarse-mesh nets for the purpose of providing specific species for pesticide analysis. Thus, their comparative value is severely limited. Robinson (1972), Ragland (1974), and Emge et al. (1974) have reported on collections of fishes from the Middle and Lower Mississippi River bordering Missouri. In these studies, habitats including dike fields, sloughs, and main channel border were sampled but were not always reported separately. Ragland (1974) found that many of the most common species were more abundant in side channels than in main channel border areas. These latter areas often included dike fields. Minnows and juveniles of several species were especially abundant in side channels. Emge et al. (1974) reported a similar abundance distribution of juvenile fishes and minnows. Robinson's (1972) report did not separate the catch by habitat, although several different types were sampled with a wide variety of gears.

133. Few side channels occurred in the study area. One exception, however, was the side channel separating Choctaw Island from the west bank in the vicinity of river miles 558-564. The uppermost part of this side channel was sampled as part of the Chicot Landing Dike Field during September 1979 and 1980. At these times, its fish assemblages were quite similar to those of the other dike fields. In many respects, dike fields and side channels are quite similar. Both provide substantial areas of 
variable depth, moderate to slack-water habitat during most river stages. In many instances, the nature of side channels is regulated by the presence of dikes (Ellis, Farabee, and Reynolds 1979). Although the relative abundance of some species in our study differed from the above studies, the species composition of our dike fields was very similar to their side channels. This suggests that, in our river reach, dike fields may replace side channels as habitat for many species.

134. Two recent studies have been accomplished in the general river reach of the present study, and are particularly pertinent for comparative purposes. NUS Corporation (1974) made fish collections in a number of river habitats in the vicinity of Grand Gulf, Miss. The James, Miss., area (vicinity of river mile 522), including some locations sampled in the present study, was sampled intensively by CDM/Limnetics (1976). Differences in the number and kinds of habitats sampled, and in gears employed, make comparisons with even these studies difficult, however. Comparisons of the relative abundances of the numerically dominant fish species in the above two studies (NUS Corporation 1974; CDM/ Limnetics 1976) with those of the present study are presented in Table 19. Gizzard shad, freshwater drum, blue catfish, flathead catfish, and river carpsucker were among the 10 most abundant species in all three studies. Other relatively abundant species included bluegill, smallmouth buffalo, carp, skipjack herring, threadfin shad, and channel catfish.

135. The numerical importance of species common to backwater habitats (e.g., carp, smallmouth buffalo, shortnose gar, black and white crappie, and river carpsucker) were greater in the NUS Corporation (1974) and CDM/Limnetics (1976) studies than in the present study. In the former studies, these habitats were more extensively sampled. Our study placed a relatively greater amount of the total effort in the dike field habitats. Minnows and shiners, which inhabit sandbar habitats in many rivers (Shipp and Hemphill 1974; Morganweck 1971; Laser et al. 1969; Starrett 1950), were considerably more abundant in the present study. The relative numerical abundance of other species was thus reduced.

136. Gear use may also have contributed to some of the differences 
shown in Table 19. Trammel nets, gill nets, and hoop nets were used most extensively by NUS Corporation (1974) and CDM/Limnetics (1976). We utilized primarily electroshocking, hoop nets, and seines. The effect of seining in the extensive sandbar areas characteristic of dike fields is evident in Table 19.

137. Species composition of hoop net samples in the above three studies was very similar, although we collected relatively fewer river carpsucker and more flathead catfish. Gill net catches were also similar, with the major differences being that we captured fewer goldeye and threadfin shad, and more skipjack herring. Seining results, although difficult to compare quantitatively, were similar in species composition.

138. Dike fields probably undergo a successional process from a more riverine to a more lentic habitat similar to that suggested for side channels (E1lis, Farabee, and Reynolds 1979; Simons et al. 1975). The eventual result is a complete filling in of most dike fields and side channels. Many dike fields on the Mississippi River have, in fact, reached this point in as few as 15 years. The rapidity and degree of depositional filling depends on many factors, including dike design. Studies to determine the effects of some dike design modifications have been completed or are under way (Pierce 1980; Kallemeyn and Novotny 1977). Even so, it is obvious that the loss of the dike field habitat on the Mississippi River would seriously affect the overall quality of fish habitat.

Length-frequency

and condition factors

139. All specimens of each species in a collection were included in calculations of mean condition factors. Since condition factors often vary between sexes and among sizes within a species (Carlander 1969), and may also vary among gear types (Ricker 1975), only general comparisons with other studies are possible.

140. River carpsucker condition factors corresponded well with those presented by Carlander (1969). CDM/Limnetics (1976), however, reported considerably higher values (1.42 versus 1.27 ). This may reflect a tendency for trammel nets, used extensively by CDM, to capture heavier 
fish at given lengths (Ricker 1971). Carlander (1969) reports spawning of river carpsucker from late April into July. Length-frequency analysis indicates that this species spawns relatively early during this period in our river reach. Although the number of intermediate-sized river carpsucker was rather low in our study, growth appeared to be somewhat faster than reported by Pflieger (1975), Robinson (1972), or Carlander (1969).

141. Condition factors of gizzard shad collected during this study averaged nearly 10 percent smaller than reported by both Carlander (1969) and CDM/Limnetics (1976). Our range of condition factors also included values lower than any given in either of the other sources. Gizzard shad spawn primarily from April to June (Carlander 1969), and in our study area they probably do so relatively early during this period (NUS Corporation 1974; CDM/Limnetics 1976). Therefore, fish collected during April are indicative of sizes attained at about 1-year intervals. Mean lengths of gizzard shad at these ages from our collections are similar to those reported by Carlander (1969), CDM/Limnetics (1976), and Pflieger (1975).

142. Mean condition factor values for flathead and channel catfish were nearly identical to those derived from Carlander (1969), while our values for blue catfish were smaller $(0.87$ versus 0.78$)$. Condition factors for all three catfish species averaged smaller at the James, Miss., site in the CDM/Limnetics (1976) study. The size distribution of these species in our study was insufficient to accurately compare relative growth rates with other studies. However, growth of channel and flathead catfish appeared to be greater than for more northern areas (Carlander 1969). Growth of blue catfish was almost certainly intermediate between northern and Louisiana brackish-water populations reported by Carlander (1969).

143. Mean condition factors for freshwater drum were similar to those found by CDM/Limnetics (1976). Freshwater drum approximately 25 to $60 \mathrm{~mm}$ TL occurred in June 1979, slightly larger at that time than reported by Pierce (1980) for Upper Mississippi River fish. This is consistent with the general observation that fish spawn earlier in the 
southern part of their range than in the northern part.

144. Mean lengths of the age groups of river shiners reported here were slightly larger than sizes listed by Carlander (1969) from more northern parts of their range. Except for a single 115-mm-TL specimen, however, the maximum size of river shiners collected $(95 \mathrm{~mm})$ was considerably smaller than that reported elsewhere (Carlander 1969).

145. Differences in the time of appearance and in mean size of Age 0 fish of some species indicated that spawning success and/or growth of juvenile fishes was quite different between 1979 and 1980. These differences were especially noticeable for channel and blue catfishes. Such year-to-year fluctuations were apparently common in riverine environments (Grossman, Moyle, and Whitaker 1981; Starrett 1951). These same dynamic changes in the populations of many river fishes may also account for much of the abundance variation between studies from the same place during different years (Grossman, Moyle, and Whitaker 1981). 
PART VI: CONCLUSIONS AND RECOMMENDATIONS

\section{Conclusions}

146. The species collected during this study, and their relative abundances, were similar to those previously reported for the Lower Mississippi River.

147. Fish populations differed considerably among the four habitat types investigated. The greatest number of species was captured in the dike field habitat (53), followed in order by the abandoned channel (31), revetted banks (27), and natural banks (24).

148. The three dike fields were similar at most sampling periods in terms of species composition but were often different in the relative abundances of the constituent species. The two natural banks were generally similar in terms of both indices, while the revetted banks showed greater variability and overall lower similarity.

149. For comparable gears, numerical catch per unit effort (C/f) was seldom significantly different among habitats. Catches on revetted banks exceeded those on natural banks except during April 1979. The C/f in the abandoned channel was approximately seven times that of any other habitat during November 1979.

150. Biomass catch per unit effort $(\mathrm{C} / \mathrm{y})$ indicated a general ranking by habitat of revetted banks - dike fields - natural banks - abandoned channel, with two exceptions. During April 1979, the C/y of dike fields and natural banks exceeded that of revetted banks. During November $1979, \mathrm{C} / \mathrm{y}$ in the abandoned channel was greatest of all habitats.

151. Condition factors showed no significant differences among habitats or seasons. In most cases, condition factors reported in this study were similar to those reported in other studies.

152. Length frequency analysis showed differences in the size ranges of fish utilizing the four habitats. In particular, Age 0 fish of many species were abundant in dike fields, and to a lesser extent, the abandoned channel. Mostly adult fish were collected at natural and revetted bank habitats. The extent to which this was caused by gear 
differences is not known. General theoretical considerations suggested, however, that the size distributions of fishes encountered in this study were realistic.

153. The differences in species, relative abundances, and length frequencies among habitats suggests that each habitat is valuable in maintaining the overall riverine ichthyofauna. Precise determination of their relative worth, however, cannot be made without further research concerning the actual use made of these habitats by the component species.

\section{$\underline{\text { Recommendations }}$}

154. Because of the very nature and functional purpose of dikes, the aquatic habitat found in a dike field is short lived. Engineering features should be incorporated during design and maintenance stages to increase longevity of the aquatic habitat of a dike field.

155. The aquatic habitats found between the levees on the Lower Mississippi River are important to different life stages of many fish species. It is realized that navigation channel maintenance receives highest priority, but care should be exercised when dikes and revetments are placed so that side- and off-channel habitat integrity is not greatly altered.

156. Additional work is needed to determine the specific uses of dikes and revetments by fish. In particular, it should be determined whether fish are benefiting directly from these structures as residents, or whether these areas are utilized only by transient species. 


\section{REFERENCES}

Baker, J. A., and Ross, S. T. 1981. "Spatial and Temporal Resource Utilization by Southeastern Cyprinids," Copeia, Vol 1981, No. 1, pp 178-189.

Barnickol, P. G., and Starrett, W. C. 1951. "Commercial and Sport Fishes of the Mississippi River Between Caruthersville, Missouri, and Dubuque, Iowa," Bulletin of the Illinois Natural History Survey, Vol 25, pp 267-350.

Boesch, D. F. 1977. "Application of Numerical Classification in Ecological Investigations of Water Pollution," U. S. EPA Ecological Research Series, EPA-600/3-77-033, National Technical Information Service, Springfield, Va.

Burress, R. M., Krieger, D. A., and Pennington, C. H. 1982. "Aquatic Biota of Bank Stabilization Structures on the Missouri River, North Dakota," Technical Report E-82-6, U. S. Army Engineer Waterways Experiment Station, CE, Vicksburg, Miss.

Carlander, K. D. 1969. Handbook of Freshwater Fishery Biology, 1st ed., Vol 1, Iowa State University Press, Ames, pp 82-89.

CDM/Limnetics. 1976. "An Ecological Study of the Lower Mississippi River," report to Middle South Services, Inc., New Orleans, La.

Ellis, J. M., Farabee, G. B., and Reynolds, J. B. 1979. "Fish Communities in Three Successional Stages of Side Channels in the Upper Mississippi River," Transactions of the Missouri Academy of Science, Vol 13, pp 5-20.

Emge, W. P., et al. 1974. "Physical, Biological, and Chemical Inventory of Twenty-Three Side Channels and Four River Border Areas, Middle Mississippi River," Miscellaneous Paper Y-74-5, U.S. Army Engineer Waterways Experiment Station, CE, Vicksburg, Miss.

Federal Water Pollution Control Administration. 1969. "Endrin Pollution in the Lower Mississippi River Basin," Washington, D. C.

Gorman, 0. T., and Karr, J. R. 1978. "Habitat Structure and Stream Fish Communities," Ecology, Vol 59, No. 3, pp 507-515.

Green, R. H. 1979. Sampling Design and Statistical Methods for Environmental Biologists, Wiley, New York.

Grossman, G. D., Moyle, P. B., and Whitaker, J. 0., Jr. 1981. "Stochasticity in Structural and Functional Characteristics of an Indiana Stream Fish Community," unpublished manuscript, Department of Wildlife and Fisheries Biology, University of California, Davis (senior author).

Harrell, H. L. 1978. "Responses of the Devil's River (Texas) Fish Community to Flooding," Copeia, Vol 1978, No. 1, pp 60-68.

Hocutt, C. H., and Stauffer, J. R., Jr., eds. 1980. Biological Monitoring of Fish, Lexington Books, Lexington, Mass. 
Kallemeyn, L. W., and Novotny, J. F. 1977. "Fish and Fish Food Organisms in Various Habitats of the Missouri River in South Dakota, Nebraska, and Iowa," U. S. Fish and Wildife Service, FWS/OBS-77-25, National

Stream Alteration Team, Columbia, Mo.

Keeley, J. W., et al. 1978. "Reservoirs and Waterways; Identification and Assessment of Environmental Quality Problems and Research Program Development," Technical Report E-78-1, U. S. Army Engineer Waterways Experiment Station, CE, Vicksburg, Miss.

Lagler, K. F. 1956. Freshwater Fishery Biology, Brown, Dubuque, Iowa. Laser, K. D., et al. 1969. "Fish Distribution in the Skunk River Below Ames, Iowa," Iowa Academy of Science, Vol 76, pp 196-205.

Miller, A. C. 1980. "Aquatic Habitat Studies on the Lower Mississippi River, River Mile 480-530; Report 1, Introduction," Miscellaneous Report E-80-1, U. S. Army Engineer Waterways Experiment Station, CE, Vicksburg, Miss.

Morganweck, R. 0. 1971. A Survey and Distribution Study of the Cyprinid Minnows (Family Cyprinidae) in the Monticello Region of the Mississippi River, M.A. Thesis, St. Cloud State College, St. Cloud, Minn.

NUS Corporation. 1974. "A Mini-Study of the Lower Mississippi River," report to Middle South Services, Inc., New Orleans, La.

Peet, R. K. 1974. "The Measurement of Species Diversity," Annual Review of Geology and Systematics, Vol 5, pp 285-307.

Pennington, C. H., et al. 1980. "Aquatic Habitat Studies on the Lower Mississippi River, River Mile 480-530; Report 5, Fish Studies - Pilot Report," Miscellaneous Paper E-80-1, U. S. Army Engineer Waterways Experiment Station, CE, Vicksburg, Miss.

Pflieger, W. L. 1971. "A Distributional Study of Missouri Fishes," University of Kansas Museum of Natural History Publication, Vol 20, No. 3, pp 225-570.

. 1975. The Fishes of Missouri, Missouri Department of Conservation, Columbia, Mo.

Pierce, R. B. 1980. Upper Mississippi River Wing Dam Notching: The Pre-notching Fish Study, M.S. Thesis, University of Wisconsin, Stevens Point, Wis.

Ragland, D. V. 1974. "Evaluation of Three Side Channels and the Main Channel Border of the Middle Mississippi River as Fish Habitat," Contract Report Y-74-1, U. S. Army Engineer District, St. Louis, St. Louis, Mo.

Rasmussen, J. L. (ed.). 1979. "A Compendium of Fishery Information on the Upper Mississippi River," Special Publication, Upper Mississippi River Conservation Commission, Rock Island, Ill.

Ricker, W. E. 1971. Methods for Assessment of Fish Production in Fresh Waters, IBP Handbook No. 3, Blackwell Scientific Publications, Oxford and Edinburgh. 
Ricker, W. E. 1975. "Computation and Interpretation of Biological Statistics of Fish Populations," Fisheries Research Board of Canada Bulletin, Vol 191, Ottawa, Ontario, Canada.

Robinson, J. W. 1972. "Population Sampling of Commerical Fish in Waters Open to Commerical Fishing," Final Report, Project 4-3-R-7, Work Plan 21, Job 2, Fisheries Research Section, Missouri Department of Conservation, Columbia, Mo.

Schramm, H. L., Jr., and Lewis, W. H. 1974. "Study of Importance of Backwater Chutes to a Riverine Fishery," Contract Report Y-74-4, U. S. Army Engineer District, St. Louis, St. Louis, Mo.

Schramm, H. L., Jr., and Pennington, C. H. 1980. "Aquatic Habitat Studies on the Lower Mississippi River, River Mile 480 to 530; Larval Fish Studies - Pilot Report," Miscellaneous Paper E-80-1, U. S. Army Engineer Waterways Experiment Station, CE, Vicksburg, Miss.

Sheldon, A. L. 1980. "Fish Communities in a New York Stream: Abundance, Association and Habitat Use," unpublished manuscript, University of Montana, Missoula.

Shipp, R. L., and Hemphill, A. F. 1974. "Effects of By-Pass Canals on Fish Populations of the Lower Alabama River," Contract Report DACW01-73C-0017, U. S. Army Engineer District, Mobile, Mobile, Ala.

Simons, D. B., et al. 1975. The River Environment, a Reference Document, U. S. Fish and Wildlife Service, Minneapolis-St. Paul, Minn. Starrett, W. C. 1950. "Distribution of the Fishes of Boone County, Iowa, with Special Reference to the Minnows and Darters," American Midland Naturalist, Vol 43, pp 112-127.

1951. "Some Factors Affecting the Abundance of Minnows in the Des Moines River, Iowa," Ecology, Vol 32, No. 1, pp 13-27.

Starrett, W. C., and Barnickol, P. G. 1955. "Efficiency and Selectivity of Commercial Fishing Devices Used on the Mississippi River," Bulletin of the Illinois Natural History Survey, Vol 26, pp 325-366. 
Table 1

Sampling Effort by Gear Type* Across Sampling Dates and Habitats

\begin{tabular}{|c|c|c|c|c|c|c|c|c|c|c|c|c|c|c|c|c|c|c|c|c|c|c|c|c|c|c|c|c|c|c|}
\hline \multirow[b]{2}{*}{ Habitat** } & \multicolumn{5}{|c|}{ Apr 79} & \multicolumn{5}{|c|}{ Jun 79} & \multicolumn{5}{|c|}{ Sep 79} & \multicolumn{5}{|c|}{ Nov 79} & \multicolumn{5}{|c|}{ Sep 80} & \multicolumn{5}{|c|}{ Totals } \\
\hline & $\underline{\mathrm{ES}}$ & $\underline{\mathrm{HN}}$ & EG & $\underline{\mathrm{SN}}$ & $\underline{\mathrm{MT}}$ & $\underline{\mathrm{ES}}$ & $\underline{\mathrm{HN}}$ & $\underline{E G}$ & SN & $\underline{\underline{\mathrm{MT}}}$ & $\underline{\mathrm{ES}}$ & $\underline{\mathrm{HN}}$ & EG & SN & $\overline{\mathrm{MT}}$ & $\overline{\mathrm{ES}}$ & $\mathrm{HN}$ & EG & $\mathrm{SN}$ & $\overline{\mathrm{MT}}$ & $\overline{\mathrm{ES}}$ & $\mathrm{HN}$ & EG & $\underline{\mathrm{SN}}$ & $\overline{\mathrm{MT}}$ & $\overline{\mathrm{ES}}$ & $\mathrm{HN}$ & EG & $\mathrm{SN}$ & $\mathrm{MT}$ \\
\hline DFC & 11 & 18 & -- & -- & -- & 10 & 62 & -- & 7 & 16 & 17 & 68 & -- & 11 & 12 & 22 & 56 & 12 & 8 & 14 & 23 & -- & 17 & 12 & -- & 83 & 204 & 29 & 38 & 42 \\
\hline DFL & 10 & 19 & -- & -- & -- & 11 & 62 & -- & 8 & 19 & 16 & 66 & -- & 17 & 22 & 13 & 36 & 6 & 10 & 17 & 10 & -- & 12 & 18 & -- & 60 & 183 & 18 & 53 & 58 \\
\hline DFT & -- & -- & -- & -- & -- & -- & -- & -- & -- & -- & 10 & 26 & 6 & 6 & 11 & -- & -- & -- & -- & -- & 13 & -- & 12 & 20 & -- & 23 & 26 & 18 & 26 & 11 \\
\hline RVW & 19 & 48 & -- & - & - & 12 & 52 & -- & -- & - & 12 & 48 & -- & -- & -- & 12 & 52 & -- & -- & -- & -- & - & -- & -- & - & 55 & 200 & - & -- & - \\
\hline RVL & 3 & 16 & -- & - & -- & 3 & 15 & -- & -- & -- & 2 & 12 & -- & -- & -- & 3 & 15 & -- & -- & -- & -- & -- & -- & -- & -- & 11 & 58 & -- & -- & -- \\
\hline NBK & 3 & 16 & -- & -- & -- & 3 & 16 & -- & -- & - & 3 & 16 & -- & -- & -- & 3 & 16 & -- & -- & -- & -- & -- & - & -- & -- & 12 & 64 & -- & -- & - \\
\hline NBA & 3 & 16 & - & - & -- & 3 & 16 & -- & -- & -- & 3 & 16 & -- & -- & -- & 3 & 15 & -- & -- & -- & -- & -- & -- & -- & -- & 12 & 63 & -- & -- & -- \\
\hline $\mathrm{ACB}$ & 9 & - & 3 & -- & -- & 6 & -- & 6 & -- & - & 6 & -- & 6 & -- & -- & 6 & -- & 6 & -- & -- & - & -- & -- & -- & -- & 27 & -- & 21 & -- & -- \\
\hline
\end{tabular}

* $\mathrm{ES}=$ electroshocker; $\mathrm{HN}=$ hoop net; $\mathrm{EG}=\mathrm{gil1}$ net; $\mathrm{SN}=$ seine; $\mathrm{MT}=$ minnow trap.

** DFC $=$ Lower Cracraft Dike Field; DFL = Leota Dike Field; DFT = Chicot Landing Dike Field; RVW = Walnut Point-Kentucky Bend Revetment; RVL = Lakeport Revetment; $\mathrm{NBK}=$ Island 88 Natural Bank; NBA = Anconia Natural Bank; ACB = Matthews Bend Abandoned Channel. The three-letter abbreviation will be used in all the following tables to designate structures and habitats sampled. 
Table 2

$\underline{\text { Families, Species, and Economic Classification of Fish Captured }}$

Family and Species

Economic

Classification*

Acipenseridae - sturgeons

Shovelnose sturgeon (Scaphirhynchus platorynchus) 2,3

Polyodontidae - paddlefishes

Paddlefish (Polyodon spathula) 3

Lepisosteidae - gars 6

Spotted gar (Lepisosteus oculatus) 6

Longnose gar (Lepisosteus osseus) 6

Shortnose gar (Lepisosteus platostomus) 6

Alligator gar (Lepisosteus spatula) 6

Amiidae - bowfins

Bowfin (Amia calva)

4,6

Anguillidae - freshwater eels

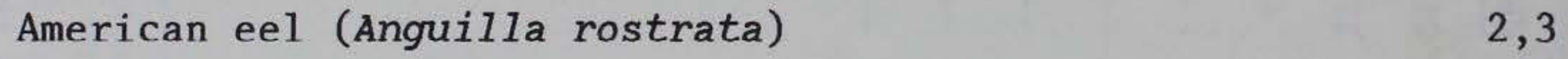

Clupeidae - herrings 5

Skipjack herring (Alosa chrysochloris) 5

Gizzard shad (Dorosoma cepedianum) 5

Threadfin shad (Dorosoma petenense) 5

Hiodontidae - mooneyes

Goldeye (Hiodon alosoides)

Mooneye (Hiodon tergisus)

Esocidae - pikes

Pickerel (Esox sp.)

$1,2,4$

Cyprinidae - minnows and carps

$2,4,5$

Carp (Cyprinus carpio)

Mississippi silvery minnow (Hybognathus nuchalis)

\section{(Continued)}

* Economic Classification (from Lagler 1956): $1=$ Sport, 2 = Commercial, 3 = Fine food, $4=$ Coarse food, $5=$ Forage, $6=$ Other . 
Table 2 (Continued)

Family and Species

Classification

Cyprinidae - minnows and carps (Continued)

Speckled chub (Hybopsis aestivalis)

Silver chub (Hybopsis storeriana)

Emerald shiner (Notropis atherinoides)

River shiner (Notropis blennius)

Pugnose minnow (Notropis emiliae)

Spottail shiner (Notropis hudsonius)

Red shiner (Notropis lutrensis)

Taillight shiner (Notropis maculatus)

Silverband shiner (Notropis shumardi)

Weed shiner (Notropis texanus)

Blacktail shiner (Notropis venustus)

Mimic shiner (Notropis volucellus)

Bullhead minnow (Pimephales vigilax)

Catostomidae - suckers

River carpsucker (Carpiodes carpio)

Quillback (Carpiodes cyprinus)

Highfin carpsucker (Carpiodes velifer)

Blue sucker (Cycleptus elongatus)

Smallmouth buffalo (Ictiobus bubalus)

Bigmouth buffalo (Ictiobus cyprinellus)

Spotted sucker (Minytrema melanops)

Ictaluridae - freshwater catfishes

Blue catfish (Ictalurus furcatus)

Yellow bullhead (Ictalurus natalis)

Channel catfish (Ictalurus punctatus)

Flathead catfish (Pylodictis olivaris)

Cyprinodontidae - killifishes

Blackspotted topminnow (Fundulus olivaceus)

Poeciliidae - livebearers

Mosquitofish (Gambusia affinis)

5,6 
Table 2 (Concluded)

Family and Species

Economic

Classification

Atherinidae - silversides

Brook silverside (Labidesthes sicculus)

Inland silverside (Menidia beryllina)

5

5

Percichthyidae - temperate basses

White bass (Morone chrysops)

Striped bass (Morone saxatilis)

$1,2,3$

1,3

Centrarchidae - sunfishes

Warmouth (Lepomis gulosus)

Orangespotted sunfish (Lepomis humulis)

Bluegill (Lepomis macrochirus)

Longear sunfish (Lepomis megalotis)

Redear sunfish (Lepomis microlophus)

Largemouth bass (Micropterus salmoides)

White crappie (Pomoxis annularis)

Black crappie (Pomoxis nigromaculatus)

Percidae - perches

Sauger (Stizostedion canadense)

$1,2,3$

Sciaenidae - drums

Freshwater drum (Aplodinotus grunniens)

Mugilidae - mullets

Striped mullet (Mugil cephalus)

2,4

2,5

1,3
6

1,3

6

1,3

1,3

1,3

1,3 
Table 3

Relative Abundance of Fish Captures at Lower Cracraft Dike Field by Sampling Date and Gear*

\begin{tabular}{|c|c|c|c|c|c|c|c|c|c|c|c|c|c|c|c|c|c|c|c|c|c|c|c|}
\hline \multirow[b]{2}{*}{ Species } & \multicolumn{3}{|c|}{$\begin{array}{c}\text { Apr } 79 \\
\%\end{array}$} & \multicolumn{5}{|c|}{$\begin{array}{c}\text { Jun } 79 \\
\%\end{array}$} & \multicolumn{5}{|c|}{$\operatorname{Sep}_{\%} 79$} & \multicolumn{5}{|c|}{$\begin{array}{c}\text { Nov } 79 \\
\%\end{array}$} & \multicolumn{4}{|c|}{$\begin{array}{c}\text { Sep } 80 \\
\%^{8} \\
\end{array}$} & \multirow{2}{*}{$\begin{array}{c}\% \\
\text { Total } \\
\end{array}$} \\
\hline & $\mathrm{HN}$ & ES & TL & $\mathrm{HN}$ & ES & MT & SN & TL & $\mathrm{HN}$ & ES & MT & SN & TL & EG & $\mathrm{HN}$ & ES MT & SN & TL & EG & ES & SN & $\mathrm{TL}$ & \\
\hline Shovelnose sturgeon & 6.7 & & 0.4 & 0.5 & & & & 0.1 & & & & & & & & & & & & & & & ** \\
\hline Paddlefish & & & & & & & & & & & & & & 0.5 & & & & 0.2 & 0.3 & & & 0.1 & 0.1 \\
\hline Sputted gar & & 0.4 & 0.4 & & & & & & & & & & & & & & & & & & & & ** \\
\hline Longnose gar & & & & & 0.4 & & & 0.1 & & 0.9 & & & 0.1 & & & & & & & & & & ** \\
\hline Shortnose gar & & & & & 0.7 & & & 0.3 & 1.5 & 1.7 & & & 0.3 & & & & & & 1.6 & & & 0.7 & 0.4 \\
\hline Alligator gar & & & & & 0.4 & & & 0.1 & & & & & & & & & & & & & & & $\star *$ \\
\hline American eel & & & & 1.1 & 0.4 & & & 0.4 & 3.1 & 2.6 & & & 0.5 & & & 0.2 & & 0.1 & & & & & 0.2 \\
\hline Skipjack herring & & 14.3 & 13.4 & & & & 1.1 & 0.4 & & 5.2 & & & 0.6 & 7.1 & & 1.8 & 0.6 & 3.0 & 1.6 & 0.5 & 0.2 & 0.9 & 1.8 \\
\hline Gizzard shad & & 82.1 & 77.0 & 1.1 & 66.5 & & 0.4 & 24.9 & & 17.2 & & 1.5 & 3.1 & 64.6 & 1.9 & 91.7 & 1.6 & 56.9 & 73.5 & 62.5 & 1.1 & 51.1 & 40.6 \\
\hline Threadfin shad & & 0.4 & 0.4 & & 3.3 & & 0.4 & 1.3 & & 0.9 & & & 0.1 & & & & 0.9 & 0.2 & & 10.8 & 0.4 & 3.4 & 1.2 \\
\hline Goldeye & & & & & 0.4 & & 3.2 & 1.3 & & 2.6 & & & 0.3 & 1.1 & & & & 0.3 & 4.3 & 0.3 & & 1.9 & 1.1 \\
\hline Mooneye & & & & & & & 0.4 & 0.1 & & 0.9 & & & 0.1 & & & 0.2 & & 0.1 & & & & & 0.1 \\
\hline Carp & 60.0 & & 3.8 & 0.5 & 2.9 & & & 1.2 & & 12.1 & & & 1.3 & & & 0.6 & & 0.2 & 0.2 & 0.2 & & 0.1 & 0.7 \\
\hline Mississippi silvery minnow & & & & & & & 24.8 & 9.2 & & & & 5.8 & 4.8 & & & 0.8 & & 0.3 & & & & & 2.3 \\
\hline Speckled chub & & & & & & & 0.4 & 0.1 & & & & 4.0 & 3.3 & & & 14.1 & & 3.6 & & & & & 1.5 \\
\hline Silver chub & & & & & 0.4 & & 0.7 & 0.4 & & & & 0.2 & 0.2 & & & & 0.9 & 0.2 & & & 0.2 & 0.0 & 0.2 \\
\hline Emerald shiner & & & & & & & & & & & & 8.9 & 7.3 & & & 0.4 & 7.2 & 2.0 & & & 30.3 & 8.0 & 5.0 \\
\hline River shiner & & & & & 0.4 & 22.2 & 26.6 & 10.3 & & & 50.0 & 60.0 & 49.6 & & & 0.2 & 48.9 & 12.6 & & & 23.9 & 6.3 & 16.5 \\
\hline Spottail shiner & & & & & & & & & & & & 0.1 & 0.1 & & & & & & & & & & *k \\
\hline Red shiner & & & & & & & & & & & & & & & & & 1.3 & 0.3 & & & 1.4 & 0.4 & 0.2 \\
\hline Silverband shiner & & & & & 0.7 & 22.2 & 5.8 & 2.7 & & & & 5.0 & 4.1 & & & & 16.0 & 4.1 & & & 2.9 & 0.8 & 2.4 \\
\hline Blacktail shiner & & & & & 1.1 & 33.3 & 1.4 & 1.3 & & & & 0.3 & 0.3 & & & & 5.0 & 1.3 & & & 9.2 & 2.4 & 1.5 \\
\hline Mimic shiner & & & & & & & 2.5 & 0.9 & & & & 0.6 & 0.5 & & & & & & & & & & 0.2 \\
\hline Bullhead minnow & & & & & & 22.2 & & 0.3 & & & & 0.5 & 0.4 & & & & 0.9 & 0.2 & & & & & 0.2 \\
\hline River carpsucker & & 0.4 & 0.4 & 0.5 & 6.9 & & 4.3 & 4.3 & 3.1 & 5.2 & & & 0.8 & 4.4 & 3.8 & 0.4 & & 1.6 & 4.5 & 0.2 & 2.9 & 2.7 & 2.2 \\
\hline Quillback & & 0.4 & 0.4 & & 0.4 & & & 0.1 & & wa & & & & 0.3 & & & & 0.1 & & & & & 0.1 \\
\hline Highfin carpsucker & & & & & 0.4 & & & 0.1 & & 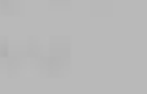 & & & & 0.3 & & & & 0.1 & 0.1 & & & 0.0 & 0.1 \\
\hline Blue sucker & & & & 3.8 & & & & 0.9 & & & & & & 0.3 & 1.9 & 0.2 & & 0.2 & & & & & 0.2 \\
\hline Smallmouth buffalo & & & & 0.5 & 1.8 & & 2.2 & 1.6 & 3.1 & & & & 0.2 & 0.8 & & & & 0.2 & 0.2 & 0.5 & & 0.2 & 0.4 \\
\hline Bigmouth buffalo & & 0.4 & 0.4 & & & & & $=$ & & 3.4 & & & 0.4 & & & & & & & & & & 0.1 \\
\hline Blue catfish & 20.0 & 0.9 & 2.1 & 19.0 & 0.7 & & 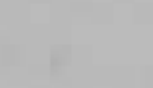 & 5.0 & 7.7 & 12.9 & & & 1.9 & 13.1 & 5.7 & & & 4.1 & 5.5 & 24.2 & & 9.8 & 6.0 \\
\hline Channel catfish & & & & 19.0 & 1.5 & & & 6.2 & 3.1 & 3.4 & 33.3 & 2.1 & 2.5 & 1.6 & 13.2 & & & 1.0 & 2.6 & & & 1.1 & 1.8 \\
\hline Flathead catfish & 13.3 & & 0.8 & 36.4 & & & & 9.0 & 67.7 & 1.7 & & & 4.4 & & 1.9 & & & 0.1 & 0.1 & 0.9 & & 0.3 & 2.3 \\
\hline Mosquitofish & & & & & & & 0.4 & 0.1 & & & & & & & & & & & & & & & ** \\
\hline Brook silverside & & & & & & & & & & & & 0.3 & 0.3 & & & & 0.3 & 0.1 & & & 0.5 & 0.1 & 0.1 \\
\hline
\end{tabular}

* Gear types are identified in column headings as follows: $\mathrm{EG}=$ experimental gill net; $\mathrm{ES}=$ electroshocker; $\mathrm{HN}=$ hoop net; $\mathrm{MT}=$ minnow trap; $\mathrm{SN}=$ seine; $\mathrm{TL}=\mathrm{total}$ for all gear types.

Values less than 0.05 . 
Table 3 (Concluded)

\begin{tabular}{|c|c|c|c|c|c|c|c|c|c|c|c|c|c|c|c|c|c|c|c|c|c|c|c|}
\hline \multirow[b]{2}{*}{ Species } & \multicolumn{3}{|c|}{$\begin{array}{c}\text { Apr } 79 \\
\%\end{array}$} & \multicolumn{5}{|c|}{$\begin{array}{c}\text { Jun } 79 \\
\%\end{array}$} & \multicolumn{5}{|c|}{$\begin{array}{c}\operatorname{Sep}_{\%} 79 \\
\end{array}$} & \multicolumn{5}{|c|}{$\begin{array}{c}\text { Nov } 79 \\
\%\end{array}$} & \multicolumn{4}{|c|}{$\begin{array}{c}\text { Sep } 80 \\
\%\end{array}$} & \multirow{2}{*}{$\begin{array}{c}\% \\
\text { Total } \\
\end{array}$} \\
\hline & HN & ES & TL & $\overline{H N}$ & ES & MT & SN & TL & HN & ES & MT & SN & TL & EG & $\mathrm{HN}$ & ES & SN & TL & $E G$ & ES & SN & TL & \\
\hline Inland silverside & & & & & & & 2.5 & 0.9 & & & & 10.2 & 8.4 & & & & 1.6 & 0.4 & & & 16.0 & 4.2 & 3.5 \\
\hline White bass & & 0.4 & 0.4 & & 2.2 & & 16.2 & 6.8 & & 5.2 & & 0.2 & 0.8 & 4.1 & 9.4 & 2.2 & & 2.5 & 0.9 & & & 0.4 & 1.8 \\
\hline Striped bass & & & & & 0.7 & & 0.4 & 0.4 & & & & & & & & & & & 0.3 & & & 0.1 & 1.8 \\
\hline Bluegill & & & & & 1.1 & & & 0.4 & & 1.7 & & 0.1 & 0.3 & & 22.6 & & 0.3 & 1.0 & & & & & 0.1 \\
\hline Largemouth bass & & & & & & & & & & & & & & & & & & & & 0.2 & & 0.0 & 0.4 \\
\hline White crappie & & & & 1.1 & 1.8 & & & 0.9 & & 6.9 & & & 0.8 & & 15.1 & & & 0.6 & 0.3 & & & 0.1 & 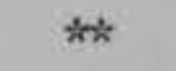 \\
\hline Black crappie & & & & & & & 1.4 & 0.5 & & 2.6 & & & 0.3 & & 9.4 & & & 0.4 & & & & & 0.5 \\
\hline Sauger & & & & & 1.8 & & 2.5 & 1.6 & & 4.3 & & & 0.5 & 1.1 & 1.9 & 0.4 & & 0.6 & 0.8 & & & 0.3 & 0.2 \\
\hline Freshwater drum & & & & 16.3 & 2.9 & & 0.4 & 5.2 & 10.8 & 8.6 & & & 1.6 & 0.8 & 13.2 & 0.8 & & 1.1 & 3.1 & & & 1.3 & 0.6 \\
\hline Striped mullet & & & & & 0.4 & & & 0.1 & & & & & & & & 0.2 & & 0.1 & 0.1 & & & 0.0 & 1.8 \\
\hline
\end{tabular}

Fish not identified to

species:

Lepomis spp.

Catostomidae

Notropis spp.

Morone spp.

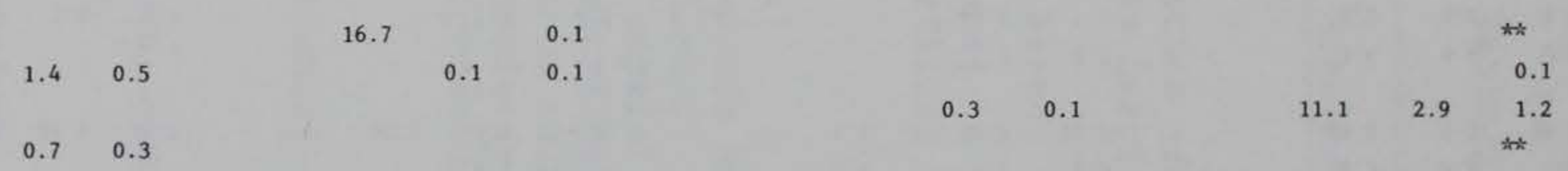

Total number caught:

Total number species: 
Table 4

Relative Percent by Weight of the Ten Dominant Fish Species

Captured from the Lower Cracraft Dike Field

\begin{tabular}{|c|c|c|c|c|c|c|}
\hline Species & Apr 79 & Jun 79 & Sep 79 & Nov 79 & Sep 80 & Tota1 \\
\hline Gizzard shad & 31.9 & 8.9 & 3.5 & 37.6 & 43.4 & 26.2 \\
\hline F1athead catfish & 3.3 & 40.5 & 34.3 & 0.7 & 1.6 & 17.1 \\
\hline Blue catfish & 6.7 & 6.5 & 4.5 & 13.0 & 17.1 & 10.8 \\
\hline Carp & 27.2 & 7.7 & 25.3 & 5.4 & 2.6 & 10.3 \\
\hline River carpsucker & - & 3.7 & 2.3 & 8.3 & 12.5 & 6.9 \\
\hline Channel catfish & -- & 10.6 & 1.4 & 3.3 & 3.9 & 4.8 \\
\hline Skipjack herring & 18.7 & * & 0.1 & 8.0 & 1.7 & 2.2 \\
\hline White bass & 0.1 & 1.5 & 3.7 & 7.0 & 1.9 & 3.0 \\
\hline Freshwater drum & -- & 6.2 & 3.1 & 2.1 & 1.6 & 3.0 \\
\hline Smallmouth buffalo & - & 4.1 & 3.0 & 3.0 & 0.9 & 2.5 \\
\hline Total percent: & 87.9 & 89.7 & 81.2 & 88.4 & 87.2 & 86.8 \\
\hline
\end{tabular}


Table 5

Relative Abundance of Fish Captured at Leota Dike Field by Sampling Date and Gear*

\begin{tabular}{|c|c|c|c|c|c|c|c|c|c|c|c|c|c|c|c|c|c|c|c|c|c|c|c|c|}
\hline \multirow[b]{2}{*}{ Species } & \multicolumn{3}{|c|}{ Apr 79} & \multicolumn{5}{|c|}{ Jun 79} & \multicolumn{5}{|c|}{ Sep 79} & \multicolumn{6}{|c|}{ Nov 79} & \multicolumn{4}{|c|}{ Sep 80} & \multirow{2}{*}{$\begin{array}{c}\% \\
\text { Total } \\
\end{array}$} \\
\hline & $\mathrm{HN}$ & ES & $\mathrm{TL}$ & $\mathrm{HN}$ & ES & MT & $\mathrm{SN}$ & TL & HN & ES & MT & SN & TL & HN & EG & ES & MT & SN & TL & EG & ES & SN & TL & \\
\hline Shovelnose sturgeon & & & & 1.2 & & & & 0.3 & & & & & & & & & & & & & & & & 0.1 \\
\hline Paddlefish & & & & & & & & & & & & & & & & & & & & 0.3 & & & 0.1 & $*$ \\
\hline Spotted gar & & 1.3 & 1.2 & & & & & & & & & & & & & 0.5 & & & 0.2 & & & & & 0.1 \\
\hline Longnose gar & & & & & 2.9 & & & 0.5 & 12.0 & 5.1 & & & 1.5 & & & 1.0 & & & 0.4 & 0.8 & & & 0.2 & 0.5 \\
\hline Shortnose gar & & 1.3 & 1.2 & 0.6 & 3.8 & & & 0.8 & 6.0 & & & & 0.5 & & 0.6 & & & & 0.2 & 1.5 & & & 0.4 & 0.5 \\
\hline Alligator gar & & & & & 1.0 & & & 0.2 & & & & & & & & & & & & & & & & * \\
\hline American eel & & & & 0.6 & & & & 0.2 & & & & & & & & & & & & & & & & ** \\
\hline Skipjack herring & 11.1 & 15.8 & 15.5 & & 1.9 & & & 0.3 & & & & 0.2 & 0.2 & & 0.6 & 1.5 & & & 0.7 & & 0.3 & & 0.1 & 1.0 \\
\hline Gizzard shad & 44.4 & 77.0 & 75.2 & 0.6 & 49.5 & & 1.8 & 9.5 & & 20.3 & & 7.9 & 8.4 & 4.0 & 66.1 & 50.2 & & 7.3 & 42.0 & 41.3 & 53.4 & 0.1 & 23.4 & 23.6 \\
\hline Threadfin shad & & & & & 10.5 & & 3.4 & 3.6 & & & & & & & & & & & & 1.0 & 14.0 & 4.8 & 5.8 & 3.4 \\
\hline Goldeye & & & & & & & & & & 6.8 & & & 0.6 & & 1.7 & 1.0 & & & 0.9 & 2.5 & 0.3 & & 0.8 & 0.6 \\
\hline Mooneye & & & & & 1.0 & & 1.5 & 1.0 & & & & & & & & 0.5 & & & 0.2 & & & & & 0.2 \\
\hline Carp & 22.2 & 1.3 & 2.5 & 2.3 & 1.9 & & & 1.0 & & 3.4 & & & 0.3 & & 0.6 & 12.2 & & & 4.7 & 3.5 & 1.2 & & 1.2 & 1.6 \\
\hline Mississippi silvery minnow & & & & & & & 2.1 & 1.1 & & 3.4 & & 4.0 & 3.6 & & & & & 1.8 & 0.4 & & 1.6 & & 0.3 & 1.1 \\
\hline Speckled chub & & & & & & & & & & & & 3.8 & 3.1 & & & & & 11.0 & 2.2 & & & & & 0.9 \\
\hline Silver chub & & & & & & & 0.9 & 0.5 & & 3.4 & & 0.8 & 1.0 & & & & & & & & & & & 0.2 \\
\hline Emerald shiner & & & & & & & 1.5 & 0.8 & & 1.7 & & 21.2 & 17.5 & & & & & 18.3 & 3.6 & & & 14.1 & 7.1 & 7.0 \\
\hline River shiner & & 0.7 & 0.6 & & & & 39.3 & 20.8 & & & 60.0 & 43.7 & 36.1 & & & & 100.0 & 43.1 & 10.1 & & & 6.4 & 3.2 & 13.4 \\
\hline Red shiner & & & & & & & 2.1 & 1.1 & & & & 1.0 & 0.8 & & 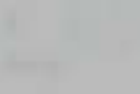 & & 5. & & & 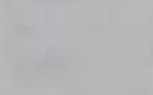 & 0.3 & 13.3 & 6.7 & 3.2 \\
\hline Silverband shiner & & & & & & 53.8 & 3.4 & 2.9 & & & & 5.2 & 4.2 & & & & & 2.8 & 0.5 & & & 5.8 & 2.9 & 2.6 \\
\hline Blacktail shiner & & & & & & & 2.7 & 1.5 & & & & 1.6 & 1.3 & & & & & 5.5 & 1.1 & & & 28.3 & 14.8 & 6.7 \\
\hline Mimic shiner & & & & & & & 7.6 & 4.0 & & & & 1.0 & 0.8 & & & & & & & & & & & 0.9 \\
\hline Bullhead minnow & & & & & & 46.2 & 3.0 & 2.6 & & & 20.0 & 4.2 & 3.6 & & & & & 0.9 & 0.2 & & & 0.7 & 0.3 & 1.3 \\
\hline River carpsucker & 11.1 & & 0.6 & 6.4 & 8.6 & & 3.0 & 4.8 & & 8.5 & & & 0.8 & 6.0 & 4.4 & 11.7 & & 0.9 & 6.5 & 13.3 & 1.6 & 0.8 & 4.4 & 4.0 \\
\hline Quillback & & & & & & & 0.3 & 0.2 & & & & & & & & & & & & & & & & $\hbar *$ \\
\hline Highfin carpsucker & & & & & & & & & & & & & & & & 0.5 & & & 0.2 & 0.3 & & & 0.1 & 0.1 \\
\hline Blue sucker & 11.1 & & 0.6 & 0.6 & & & & 0.2 & & & & & & & & & & & & & & & & 0.1 \\
\hline Smal1mouth buffalo & & 0.7 & 0.6 & 2.9 & 3.8 & & 4.9 & 4.0 & 2.0 & 5.1 & & & 0.6 & & 2.2 & 1.0 & & & 1.1 & 1.3 & & & 0.3 & 1.2 \\
\hline Bigmouth buffalo & & 0.7 & 0.6 & & 1.0 & & & 0.2 & & & & & & & & & & & & & & & & 0.1 \\
\hline Blue catfish & & 0.7 & 0.6 & 11.0 & & & & 3.1 & 10.0 & 3.4 & 20.0 & 0.2 & 1.5 & 20.0 & 11.1 & 0.5 & & & 5.6 & 10.3 & 19.9 & & 7.3 & 4.9 \\
\hline Channel catfish & & & & 19.1 & 1.0 & & & 5.5 & 6.0 & & & & 0.5 & 4.0 & 3.9 & 7.3 & & & 4.3 & 12.5 & & 0.1 & 3.5 & 3.3 \\
\hline Flathead catfish & & & & 36.4 & 3.8 & & & 10.8 & 58.0 & 5.1 & & & 5.2 & 14.0 & 0.6 & & & & 1.4 & 2.0 & 1.6 & & 0.9 & 3.5 \\
\hline Blackspotted topminnow & & & & & & & & & & & & & & & & & & & & & & 0.4 & 0.2 & $* *$ \\
\hline Mosquitofish & & & & & & & & & & & & & & & & & & & & & & 1.8 & 0.9 & 0.4 \\
\hline Brook silverside & & & & & & & & & & & & 0.6 & 0.5 & & & & & 0.9 & 0.2 & & & 2.1 & 1.0 & 0.5 \\
\hline
\end{tabular}

* Gear types are identified in column headings as follows: $\mathrm{EG}=$ experimental gill net; ES = electroshocker; HN = hoop net; MT = minnow trap; SN = seine; TL = total for all gear types.

** Values less than 0.05 
Table 5 (Concluded)

\begin{tabular}{|c|c|c|c|c|c|c|c|c|c|c|c|c|c|c|c|c|c|c|c|c|c|c|c|c|}
\hline \multirow[b]{2}{*}{ Species } & \multicolumn{3}{|c|}{$\begin{array}{c}\text { Apr } 79 \\
\% \\
\end{array}$} & \multicolumn{5}{|c|}{$\begin{array}{c}\text { Jun } 79 \\
\%\end{array}$} & \multicolumn{5}{|c|}{$\begin{array}{c}\text { Sep }_{\%} 79 \\
\end{array}$} & \multicolumn{6}{|c|}{$\begin{array}{c}\text { Nov } 79 \\
\%\end{array}$} & \multicolumn{4}{|c|}{$\begin{array}{c}\operatorname{Sep}_{\%} 80 \\
\end{array}$} & \multirow{2}{*}{$\begin{array}{c}\% \\
\text { Total } \\
\end{array}$} \\
\hline & $\mathrm{HN}$ & ES & TL & $\mathrm{HN}$ & ES & MT & SN & TL & HN & ES & $\mathrm{MT}$ & SN & TL & HN & EG & ES & MT & SN & $\mathrm{TL}$ & EG & ES & SN & $\mathrm{TL}$ & \\
\hline Island silverside & & & & & & & 0.9 & 0.5 & & & & 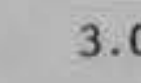 & 2.4 & & & & & 5.5 & 1.1 & & & 6.9 & 3.5 & 2.2 \\
\hline White bass & & & & & 1.9 & & 7.6 & 4.4 & & & & 0.4 & 0.3 & & 0.6 & 2.4 & & & 1.1 & 1.0 & 1.6 & & 0.6 & 1.3 \\
\hline Striped bass & & & & & & & & & & 1.7 & & & 0.2 & $=$ & & & & & & 0.3 & & 0.1 & 0.1 & 0.1 \\
\hline Bluegill & & 0.7 & & & 1.0 & & & 0.2 & & 1.7 & & & 0.2 & 26.0 & & 1.0 & & & 2.7 & & 0.9 & 1.5 & 1.0 & 0.9 \\
\hline Longear sunfish & & & & 0.6 & & & & 0.2 & & & & & & & & & & & & & & & & 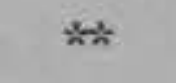 \\
\hline Largemouth bass & & & & & & & & & & & & & & & & 0.5 & & & 0.2 & & 0.9 & & 0.2 & 0.1 \\
\hline White crappie & & & & & 1.9 & & & 0.3 & & 8.5 & & & 0.8 & 20.0 & 0.6 & 0.5 & & & 2.2 & 1.5 & & & 0.4 & 0.7 \\
\hline Black crappie & & & & & & & 0.3 & 0.2 & & 3.4 & & & 0.3 & 6.0 & & & & & 0.5 & 0.3 & & & 0.1 & 0.2 \\
\hline Sauger & & & & & 1.0 & & 1.2 & 0.8 & & 6.8 & & 0.8 & 1.3 & & 5.0 & 2.4 & & & 2.5 & 0.8 & 1.2 & & 0.5 & 1.0 \\
\hline Freshwater drum & & & & 17.9 & 1.0 & & 4.6 & 7.6 & 6.0 & 11.9 & & & 1.6 & & 2.2 & 5.4 & & & 2.7 & 6.0 & 0.9 & & 1.9 & 2.9 \\
\hline ped mullet & & & & & 2.9 & & & 0.5 & & & & & & & & & & & & & & & & 0.1 \\
\hline
\end{tabular}

Fish not identified to

species:

Morone spp.

Notropis spp.

Hybops is spp.

$5.5 \quad 2.9$

$2.1 \quad 1.1$

Lepomis spp.

Total number caught:

Total number species:
$1.8 \quad 0.4$

618

30 
Table 6

Relative Percent by Weight of the Ten Dominant Fish Species Captured from the Leota Dike Field

\begin{tabular}{|c|c|c|c|c|c|c|}
\hline Species & Apr 79 & Jun 79 & Sep 79 & Nov 79 & Sep 80 & Total \\
\hline Carp & 28.7 & 6.1 & 5.0 & 38.9 & 18.1 & 19.0 \\
\hline Flathead catfish & - & 31.7 & 32.4 & 3.1 & 6.0 & 14.9 \\
\hline River carpsucker & 2.4 & 10.2 & 3.9 & 10.2 & 23.9 & 13.7 \\
\hline Gizzard shad & 19.4 & 6.3 & 1.7 & 17.0 & 13.6 & 11.4 \\
\hline Channel catfish & - & 16.1 & 0.6 & 9.6 & 12.9 & 11.0 \\
\hline Smal1mouth buffalo & 7.9 & 8.1 & 8.5 & 2.4 & 4.4 & 5.5 \\
\hline Blue catfish & 1.5 & 3.0 & 2.7 & 5.3 & 8.3 & 5.2 \\
\hline Longnose gar & - & 2.5 & 25.8 & 0.2 & 1.6 & 4.1 \\
\hline Freshwater drum & -- & 6.2 & 4.2 & 2.7 & 2.7 & 3.7 \\
\hline Shortnose gar & 5.1 & 3.7 & 4.1 & 1.0 & 2.4 & 2.7 \\
\hline Total percent: & 65.0 & 93.9 & 88.9 & 90.4 & 93.9 & 91 \\
\hline
\end{tabular}


Table 7

Relative Abundance of Fish Captures at Chicot Landing Dike Field

by Sampling Date and Gear*

\begin{tabular}{|c|c|c|c|c|c|c|c|c|c|c|c|}
\hline \multirow[b]{2}{*}{ Species } & \multicolumn{6}{|c|}{ Sep $79, \%$} & \multicolumn{4}{|c|}{ Sep $80, \%$} & \multirow{2}{*}{$\begin{array}{c}\% \\
\text { Total } \\
\end{array}$} \\
\hline & $\mathrm{HN}$ & $\mathrm{EG}$ & $\mathrm{ES}$ & MT & SN & TL & $\mathrm{EG}$ & $\mathrm{ES}$ & SN & TL & \\
\hline Longnose gar & & 9.5 & & & & 0.3 & 2.0 & 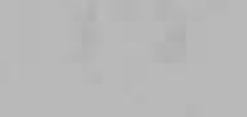 & & 0.3 & 0.3 \\
\hline Shortnose gar & & 9.5 & 3.1 & & 0.2 & 0.7 & 2.4 & 2.7 & & 0.5 & 0.6 \\
\hline Skipjack herring & & & 4.7 & & 0.2 & 0.5 & 0.4 & & 0.1 & 0.1 & 0.3 \\
\hline Gizzard shad & 33.3 & & 40.6 & & 4.8 & 8.2 & 39.8 & 37.3 & es & 8.1 & 8.2 \\
\hline Threadfin shad & & & & & 0.6 & 0.5 & & 1.3 & 2.6 & 2.1 & 1.6 \\
\hline Goldeye & & & 7.8 & & & 0.7 & & & & & 0.2 \\
\hline Mooneye & & & 3.1 & & & 0.3 & & & & & 0.1 \\
\hline Carp & & 14.3 & 4.7 & & & 0.8 & 2.8 & 1.3 & & 0.5 & 0.6 \\
\hline Mississippi silvery minnow & & & 1.6 & & 4.4 & 3.7 & & & 0.2 & 0.2 & 1.3 \\
\hline Speckled chub & & & & & 6.0 & 4.8 & & & 1.4 & 1.1 & 2.3 \\
\hline Silver chub & & & 1.6 & & 5.3 & 4.4 & & & & & 1.5 \\
\hline Emerald shiner & & & 12.5 & & 6.0 & 5.9 & & & 3.8 & 3.0 & 3.9 \\
\hline River shiner & & & & 20.7 & 4.2 & 4.2 & & & 7.1 & 5.7 & 5.2 \\
\hline Pugnose minnow & & & & & 0.2 & 0.1 & & & & & $*$ \\
\hline Spottail shiner & & & & & 0.2 & 0.1 & & & & & $*$ \\
\hline & & & & (Con & inued) & & & & & & \\
\hline
\end{tabular}

* Gear types are identified in column headings as follows: EG = experimental gill net; ES = electroshocker; $\mathrm{HN}=$ hoop net; $\mathrm{MT}=$ minnow trap; $\mathrm{SN}=$ seine; $\mathrm{TL}=$ total for all gear types.

** Values less than 0.05 . 
Table 7 (Continued)

\begin{tabular}{|c|c|c|c|c|c|c|c|c|c|c|c|}
\hline \multirow[b]{2}{*}{ Species } & \multicolumn{6}{|c|}{ Sep $79, \%$} & \multicolumn{4}{|c|}{ Sep $80, \%$} & \multirow{2}{*}{$\begin{array}{c}\% \\
\text { Total } \\
\end{array}$} \\
\hline & $\mathrm{HN}$ & EG & ES & MT & SN & TL & EG & ES & SN & TL & \\
\hline Red shiner & & & & & 1.8 & 1.4 & & & 0.2 & 0.1 & 0.6 \\
\hline Taillight shiner & & & & 6.9 & & 0.3 & & & & & 0.1 \\
\hline Silverband shiner & & & & 13.8 & 23.3 & 19.3 & & & 39.5 & 31.3 & 27.4 \\
\hline Weed shiner & & & & & 0.3 & 0.3 & & & & & 0.1 \\
\hline Blacktail shiner & & & & & 5.5 & 4.4 & & & 21.9 & 17.4 & 13.1 \\
\hline Mimic shiner & & & & & 4.2 & 3.4 & & & 0.2 & 0.2 & 1.2 \\
\hline Bullhead minnow & & & & 13.8 & 21.6 & 18.0 & & & 3.9 & 3.1 & 8.0 \\
\hline River carpsucker & 9.1 & & 4.7 & & 0.5 & 1.2 & 19.9 & & 0.4 & 3.5 & 2.7 \\
\hline Quillback & 3.0 & & & & & 0.1 & & & & & $* *$ \\
\hline Highfin carpsucker & & & 3.1 & & & 0.3 & & & 0.1 & 0.1 & 0.1 \\
\hline Blue sucker & & & & & & & & 1.3 & & 0.1 & $* t$ \\
\hline Smallmouth buffalo & 3.0 & 4.8 & 1.6 & & & 0.4 & 1.2 & & & 0.2 & 0.3 \\
\hline Bigmouth buffalo & & & & & & & 0.8 & & 0.1 & 0.2 & 0.1 \\
\hline Blue catfish & 12.1 & 19.0 & 1.6 & & & 1.2 & 13.9 & 54.7 & 0.2 & 5.0 & 3.8 \\
\hline Channel catfish & & & 1.6 & 24.1 & 2.7 & 3.3 & 3.2 & & 0.6 & 1.0 & 1.8 \\
\hline Flathead catfish & 24.2 & & & & & 1.0 & 0.4 & 1.3 & & 0.1 & 0.4 \\
\hline Mosquitofish & & & & & & & & & 0.8 & 0.6 & 0.4 \\
\hline Brook silverside & & & & & 1.8 & 1.4 & & & 0.1 & 0.1 & 0.5 \\
\hline Inland silverside & & & & & 3.1 & 2.5 & & & 2.1 & 1.7 & 1.9 \\
\hline & & & & (Con & inued) & & & & & & \\
\hline
\end{tabular}

** Values less than 0.05 
Table 7 (Concluded)

\begin{tabular}{|c|c|c|c|c|c|c|c|c|c|c|c|}
\hline \multirow[b]{2}{*}{ Species } & \multicolumn{6}{|c|}{ Sep $79, \%$} & \multicolumn{4}{|c|}{ Sep $80, \%$} & \multirow{2}{*}{$\begin{array}{c}\% \\
\text { Total } \\
\end{array}$} \\
\hline & $\mathrm{HN}$ & EG & $\mathrm{ES}$ & MT & SN & TL & $\mathrm{EG}$ & $\mathrm{ES}$ & SN & TL & \\
\hline White bass & & & & & 0.3 & 0.3 & 1.6 & & 0.2 & 0.4 & 0.3 \\
\hline Striped bass & & & & & & & & & 0.1 & 0.1 & $* *$ \\
\hline Warmouth & & & & 3.4 & & 0.1 & & & 0.1 & 0.1 & 0.1 \\
\hline Bluegill & & & & 17.2 & 1.1 & 1.6 & & & 5.2 & 4.1 & 3.3 \\
\hline White crappie & & & 1.6 & & & 0.1 & 0.4 & & & 0.1 & 0.1 \\
\hline Black crappie & 27.3 & & & & & 1.2 & 0.4 & & & 0.1 & 0.4 \\
\hline Sauger & 3.0 & & 3.1 & & & 0.4 & & & & & 0.1 \\
\hline Freshwater drum & 18.2 & 9.5 & 3.1 & & 1.5 & 2.5 & 10.8 & & 0.1 & 1.8 & 2.0 \\
\hline \multicolumn{12}{|l|}{$\begin{array}{l}\text { Fish not identified to } \\
\text { species: }\end{array}$} \\
\hline Carpiodes spp. & & & & & 0.2 & 0.1 & & & & & $*$ \\
\hline Lepomis spp. & & & & & 0.2 & 0.1 & & & 7.0 & 5.5 & 3.8 \\
\hline Notropis spp. & & & & & & & & & 1.4 & 1.1 & 0.7 \\
\hline Centrarchidae & & & & & & & & & 0.3 & 0.3 & 0.2 \\
\hline Cyprinidae & & & & & & & & & 0.2 & 0.2 & 0.1 \\
\hline Dorosoma spp. & & & & & & & & & 0.2 & 0.1 & 0.1 \\
\hline Esox spp. & & & & & & & & & 0.1 & 0.1 & $* t$ \\
\hline Total number caught: & 33 & 21 & 64 & 29 & 619 & 766 & 251 & 75 & 1247 & 1573 & 2339 \\
\hline Total number species: & 9 & 6 & 17 & 7 & 24 & 38 & 15 & 7 & 24 & 33 & 42 \\
\hline
\end{tabular}

** Values less than 0.05 
Table 8

Relative Percent by Weight of the Ten Dominant Fish Species Captured from the Chicot Landing Dike Field

\begin{tabular}{lrrrr}
\hline \multicolumn{1}{c}{ Species } & Sep 79 & & Sep 80 & Total \\
\cline { 5 - 5 } Blue catfish & 14.2 & 36.0 & 30.9 \\
River carpsucker & 8.4 & 19.3 & 16.8 \\
Gizzard shad & 5.8 & 17.0 & 14.4 \\
Carp & 19.7 & 5.5 & 8.8 \\
Longnose gar & 5.8 & 7.9 & 7.4 \\
Channel catfish & 1.3 & 4.0 & 3.4 \\
Freshwater drum & 5.6 & 2.7 & 3.4 \\
Flathead catfish & 12.0 & 0.5 & 3.2 \\
Smallmouth buffalo & 6.6 & 1.5 & 2.7 \\
Shortnose gar & 3.9 & 1.8 & 2.3 \\
Total percent: & 83.3 & 96.2 & 93.3
\end{tabular}


Table 9

Similarity Comparisons of Three Dike Field Habitats on the Lower Mississippi River

\begin{tabular}{|c|c|c|c|c|c|c|}
\hline \multirow[b]{3}{*}{ Sampling Date } & \multicolumn{6}{|c|}{ Location Pair } \\
\hline & \multicolumn{2}{|c|}{ DFL-DFC* } & \multicolumn{2}{|c|}{ DFT-DFC } & \multicolumn{2}{|c|}{ DFT-DFL } \\
\hline & & PS** & $\mathrm{CC}$ & PS & & PS \\
\hline Apr 79 & 0.41 & 0.77 & & & & \\
\hline Jun 79 & 0.75 & 0.66 & & & & \\
\hline Sep 79 & 0.74 & 0.62 & 0.77 & 0.40 & 0.74 & 0.48 \\
\hline Nov 79 & 0.69 & 0.52 & & & & \\
\hline Sep 80 & 0.71 & 0.57 & 0.55 & 0.36 & 0.72 & 0.51 \\
\hline Mean: & 0.66 & 0.63 & 0.66 & 0.38 & 0.73 & 0.50 \\
\hline
\end{tabular}


Table 10

Relative Abundance of Fish Captured at Walnut Point-Kentucky Bend

Revetment by Sampling Date and Gear*

\begin{tabular}{|c|c|c|c|c|c|c|c|c|c|c|c|c|c|}
\hline \multirow[b]{2}{*}{ Species } & \multicolumn{3}{|c|}{ Apr 79} & \multicolumn{3}{|c|}{$\begin{array}{c}\text { Jun } 79 \\
\%\end{array}$} & \multicolumn{3}{|c|}{$\begin{array}{cc}\text { Sep } & 79 \\
& \% \\
\end{array}$} & \multicolumn{3}{|c|}{$\begin{array}{c}\text { Nov } 79 \\
\% \\
\end{array}$} & \multirow{2}{*}{$\begin{array}{c}\% \\
\text { Total } \\
\end{array}$} \\
\hline & $\mathrm{HN}$ & ES & $\mathrm{TL}$ & $\mathrm{HN}$ & ES & TL & $\mathrm{HN}$ & ES & $\mathrm{TL}$ & $\mathrm{HN}$ & ES & TL & \\
\hline Shovelnose sturgeon & 5.4 & & 1.0 & 1.2 & & 0.4 & & & & & & & 0.4 \\
\hline Spotted gar & & 2.6 & 2.1 & & & & & & & & & & 0.5 \\
\hline Longnose gar & & & & & 4.1 & 2.6 & & 1.3 & 0.8 & & & & 0.8 \\
\hline Shortnose gar & & 0.6 & 0.5 & & 6.1 & 3.9 & & & & & & & 1.2 \\
\hline Bowfin & & 0.6 & 0.5 & & & & & & & & & & 0.1 \\
\hline American eel & 2.7 & & 0.5 & & & & 3.8 & & & 16.7 & & 1.3 & 0.8 \\
\hline Skipjack herring & 2.7 & 3.2 & 3.1 & & 6.1 & 3.9 & & & & & 0.4 & 0.3 & 1.9 \\
\hline Gizzard shad & 10.8 & 80.6 & 67.2 & & 31.8 & 20.3 & & & & & 92.5 & 85.2 & 50.7 \\
\hline Threadfin shad & & 8.4 & 6.8 & & 4.7 & 3.0 & & & & & & & 2.3 \\
\hline Goldeye & & & & & & & & 1.3 & 0.8 & 4.2 & 1.8 & 2.0 & 0.8 \\
\hline Carp & 24.3 & 1.3 & 5.7 & 2.4 & 11.5 & 8.2 & & 13.9 & 8.4 & & & & 4.8 \\
\hline River shiner & & 0.6 & 0.5 & & & & & & & & & & 0.1 \\
\hline Silverband shiner & & & & & 0.7 & 0.4 & & & & & & & 0.1 \\
\hline River carpsucker & 5.4 & & 1.0 & & 5.4 & 3.4 & & & & 16.7 & 1.4 & 2.6 & 2.1 \\
\hline Blue sucker & 5.4 & & 1.0 & 6.0 & 0.7 & 2.6 & 19.2 & 21.5 & 20.6 & & & & 4.1 \\
\hline
\end{tabular}

* Gear types are identified in column headings as follows: ES = electroshocker; HN = hoop net; TL = total for all gear types. 
Table 10 (Concluded)

\begin{tabular}{|c|c|c|c|c|c|c|c|c|c|c|c|c|c|}
\hline \multirow[b]{2}{*}{ Species } & \multicolumn{3}{|c|}{$\begin{array}{c}\text { Apr } 79 \\
\%\end{array}$} & \multicolumn{3}{|c|}{$\begin{array}{c}\text { Jun } 79 \\
\%\end{array}$} & \multicolumn{3}{|c|}{$\begin{array}{c}\text { Sep } 79 \\
\%\end{array}$} & \multicolumn{3}{|c|}{$\begin{array}{c}\text { Nov } 79 \\
\%\end{array}$} & \multirow{2}{*}{$\begin{array}{c}\% \\
\text { Total } \\
\end{array}$} \\
\hline & $\mathrm{HN}$ & ES & TL & $\mathrm{HN}$ & ES & TL & $\mathrm{HN}$ & ES & $\mathrm{TL}$ & $\mathrm{HN}$ & ES & $\mathrm{TL}$ & \\
\hline Sma11mouth buffalo & & & & 11.9 & 9.5 & 10.3 & 7.7 & 5.1 & 6.1 & 4.2 & 0.7 & 1.0 & 4.1 \\
\hline Bigmouth buffalo & & & & & 0.7 & 0.4 & & & & & & & 0.1 \\
\hline Blue catfish & 13.5 & & 2.6 & 11.9 & & 4.3 & 7.7 & 49.4 & 32.8 & 4.2 & 0.4 & 0.7 & 7.0 \\
\hline Channel catfish & 13.5 & & 2.6 & 11.9 & & 4.3 & 3.8 & & 1.5 & 4.2 & & 0.3 & 1.5 \\
\hline Flathead catfish & 5.4 & & 1.0 & 36.9 & 7.4 & 18.1 & 46.2 & 2.5 & 19.8 & 37.5 & & 3.0 & 9.1 \\
\hline White bass & & & & & 2.0 & 1.3 & & & & & 0.7 & 0.7 & 0.6 \\
\hline Bluegil1 & & 0.6 & 0.5 & & 0.7 & 0.4 & & 1.3 & 0.8 & & & & 0.4 \\
\hline Largemouth bass & & 0.6 & 0.5 & & & & & & & & & & 0.1 \\
\hline Sauger & 2.7 & 0.6 & 1.0 & & & & & & & 12.5 & & 1.0 & 0.6 \\
\hline Freshwater drum & 8.1 & & 1.6 & 17.9 & 8.1 & 11.6 & 11.5 & 1.3 & 5.3 & & 2.1 & 2.0 & 5.0 \\
\hline Striped mullet & & & & & 0.7 & 0.4 & & 2.5 & 1.5 & & & & 0.4 \\
\hline $\begin{array}{l}\text { Total number } \\
\text { caught: }\end{array}$ & 37 & 155 & 192 & 84 & 148 & 232 & 52 & 79 & 131 & 24 & 281 & 305 & 860 \\
\hline Number of species: & 12 & 11 & 19 & 8 & 16 & 19 & 7 & 10 & 11 & 8 & 8 & 12 & 26 \\
\hline
\end{tabular}


Table 11

Relative Percent by Weight of the Fifteen Dominant

Fish Species Captured from Bank Habitats

\begin{tabular}{|c|c|c|c|c|}
\hline \multirow[b]{2}{*}{ Species } & \multicolumn{4}{|c|}{ Habitat } \\
\hline & $\overline{\overline{\mathrm{NBA}}}$ & $\overline{\mathrm{NBK}}$ & RVL & RVW \\
\hline Flathead catfish & 24.5 & 35.3 & 12.0 & 20.0 \\
\hline Gizzard shad & 20.5 & 12.5 & 15.2 & 10.7 \\
\hline Blue catfish & 7.7 & 2.9 & 4.5 & 11.5 \\
\hline Blue sucker & 8.6 & & 15.9 & 10.0 \\
\hline Freshwater drum & 4.7 & 15.8 & 3.1 & 4.0 \\
\hline Carp & 3.0 & 5.4 & & 20.7 \\
\hline Bigmouth buffalo & 14.8 & 4.4 & 2.1 & \\
\hline Channel catfish & & & 39.9 & 3.5 \\
\hline Sma11mouth buffalo & & 1.7 & 1.2 & 9.2 \\
\hline River carpsucker & & & & 2.5 \\
\hline American ee1 & 2.3 & 4.1 & & \\
\hline Shovelnose sturgeon & 2.9 & & 5.2 & \\
\hline Skipjack herring & 4.1 & & 0.9 & \\
\hline Shortnose gar & & 2.8 & & 1.9 \\
\hline Longnose gar & & 5.5 & & \\
\hline Total percent: & 93.1 & 90.4 & 100.0 & 94.0 \\
\hline
\end{tabular}


Table 12

Relative Abundance of Fish Captured at Lakeport Revetment

by Sampling Date and Gear*

\begin{tabular}{|c|c|c|c|c|c|c|c|c|c|c|c|c|c|}
\hline \multirow[b]{2}{*}{ Species } & \multicolumn{3}{|c|}{$\begin{array}{c}\text { Apr } 79 \\
\%\end{array}$} & \multicolumn{3}{|c|}{$\begin{array}{c}\text { Jun } 79 \\
\% \\
\end{array}$} & \multicolumn{3}{|c|}{$\begin{array}{c}\text { Sep } 79 \\
\%\end{array}$} & \multicolumn{3}{|c|}{$\begin{array}{c}\text { Nov } 79 \\
\%\end{array}$} & \multirow{2}{*}{$\begin{array}{c}\% \\
\text { Tota1 } \\
\end{array}$} \\
\hline & $\mathrm{HN}$ & ES & TL & $\mathrm{HN}$ & ES & TL & HN & ES & TL & $\mathrm{HN}$ & ES & TL & \\
\hline $\begin{array}{l}\text { Shovelnose sturgeon } \\
\text { Longnose gar } \\
\text { Skipjack herring } \\
\text { Gizzard shad } \\
\text { Threadfin shad }\end{array}$ & 50.0 & $\begin{array}{l}33.3 \\
66.7\end{array}$ & $\begin{array}{l}26.3 \\
21.1 \\
31.6\end{array}$ & & $\begin{array}{r}93.1 \\
1.9\end{array}$ & $\begin{array}{r}67.4 \\
1.4\end{array}$ & 16.7 & & 10.5 & & 77.8 & 43.8 & $\begin{array}{r}2.6 \\
0.4 \\
1.5 \\
58.9 \\
1.1\end{array}$ \\
\hline $\begin{array}{l}\text { Goldeye } \\
\text { River carpsucker } \\
\text { Blue sucker } \\
\text { Smallmouth buffalo } \\
\text { Bigmouth buffalo }\end{array}$ & 10.0 & & 5.3 & $\begin{array}{l}1.6 \\
3.3\end{array}$ & $\begin{array}{l}0.6 \\
1.3\end{array}$ & $\begin{array}{l}0.5 \\
0.5 \\
0.9 \\
0.9\end{array}$ & & $\begin{array}{l}85.7 \\
14.3\end{array}$ & $\begin{array}{r}31.8 \\
5.3\end{array}$ & 28.6 & 22.2 & $\begin{array}{l}12.5 \\
12.5\end{array}$ & $\begin{array}{l}1.1 \\
0.4 \\
4.0 \\
0.7 \\
0.4\end{array}$ \\
\hline $\begin{array}{l}\text { Blue catfish } \\
\text { Channel catfish } \\
\text { Flathead catfish } \\
\text { White crappie } \\
\text { Sauger } \\
\text { Freshwater drum }\end{array}$ & 10.0 & & 10.5 & $\begin{array}{r}3.3 \\
75.4 \\
3.3\end{array}$ & 1.9 & $\begin{array}{r}0.9 \\
20.8 \\
0.9 \\
0.5 \\
5.0\end{array}$ & $\begin{array}{l}66.7 \\
16.7\end{array}$ & & $\begin{array}{l}42.1 \\
10.5\end{array}$ & $\begin{array}{l}14.3 \\
28.6 \\
28.6\end{array}$ & & $\begin{array}{r}6.3 \\
12.5 \\
12.5\end{array}$ & $\begin{array}{r}4.4 \\
17.1 \\
2.6 \\
0.4 \\
0.7 \\
4.0\end{array}$ \\
\hline $\begin{array}{l}\text { Total number } \\
\text { caught: }\end{array}$ & 10 & 9 & 19 & 61 & 160 & 221 & 12 & 7 & 19 & 7 & 9 & 16 & 275 \\
\hline Number of species: & 5 & 2 & 6 & 6 & 7 & 12 & 3 & 2 & 5 & 4 & 2 & 6 & 16 \\
\hline
\end{tabular}

* Gear types are identified in column headings as follows: $\mathrm{ES}=$ electroshocker; HN = hoop net; TL = total for all gear types. 
Table 13

Relative Abundance of Fish Captured at Anconia Natural Bank

by Sampling Date and Gear*

\begin{tabular}{|c|c|c|c|c|c|c|c|c|c|c|c|c|c|}
\hline \multirow[b]{2}{*}{ Species } & \multicolumn{3}{|c|}{$\begin{array}{c}\text { Apr } 79 \\
\%\end{array}$} & \multicolumn{3}{|c|}{$\begin{array}{c}\text { Jun } 79 \\
\%\end{array}$} & \multicolumn{3}{|c|}{$\operatorname{Sep}_{\%} 79$} & \multicolumn{3}{|c|}{$\begin{array}{c}\text { Nov } 79 \\
\%\end{array}$} & \multirow{2}{*}{$\begin{array}{c}\% \\
\text { Total } \\
\end{array}$} \\
\hline & HN & ES & TL & $\mathrm{HN}$ & $\mathrm{ES}$ & $\mathrm{TL}$ & $\mathrm{HN}$ & ES & $\overline{T L}$ & $\mathrm{HN}$ & ES & $\overline{T L}$ & \\
\hline Shovelnose sturgeon & 18.2 & & 3.3 & & & & & & & & & & 0.9 \\
\hline Longnose gar & & & & & 1.1 & 0.9 & & & & & & & 0.5 \\
\hline Shortnose gar & & & & & & & & & & 11.1 & 77.3 & 3.2 & 0.5 \\
\hline American eel & & & & 13.3 & & 1.9 & & & & & & & 0.9 \\
\hline Skipjack herring & & 20.0 & 16.4 & & 1.1 & 0.9 & & & & & 9.1 & 6.5 & 5.9 \\
\hline G1zzard shad & & 78.0 & 63.9 & & 86.0 & 74.1 & & 100.0 & 4.8 & & & 54.8 & 62.0 \\
\hline Threadfin shad & & & & & 8.6 & 7.4 & & & & & & & 3.6 \\
\hline Goldeye & & & & & & & & & & & 4.5 & 3.2 & 0.5 \\
\hline Carp & & & & & & & 5.0 & & 4.8 & & & & 0.5 \\
\hline Mississippi silvery minnow & & & & & & & & & & & 4.5 & 3.2 & 0.5 \\
\hline Blacktail shiner & & & & & 1.1 & 0.9 & & & & & & & 0.5 \\
\hline River carpsucker & & & & & & & & & & 11.1 & & 3.2 & 0.5 \\
\hline Blue sucker & & & & & & & 10.0 & & 9.5 & & & & 0.9 \\
\hline Bigmouth buffalo & & 2.0 & 1.6 & 6.7 & & 0.9 & & & & & & & 0.9 \\
\hline Blue catfish & 18.2 & & 3.3 & 13.3 & & 1.9 & 35.0 & & 33.3 & 22.2 & 6.5 & & 5.9 \\
\hline
\end{tabular}

* Gear types are Identified in column headings as follows: $\mathrm{ES}=$ electroshocker; HN = hoop net; TL = total for a11 gear types. 
Table 13 (Concluded)

\begin{tabular}{|c|c|c|c|c|c|c|c|c|c|c|c|c|c|}
\hline \multirow[b]{2}{*}{ Species } & \multicolumn{3}{|c|}{$\begin{array}{c}\text { Apr } 79 \\
\%\end{array}$} & \multicolumn{3}{|c|}{$\begin{array}{c}\text { Jun } 79 \\
\%\end{array}$} & \multicolumn{3}{|c|}{$\begin{array}{c}\text { Sep } 79 \\
\% \\
\end{array}$} & \multicolumn{3}{|c|}{$\begin{array}{c}\text { Nov } 79 \\
\%\end{array}$} & \multirow{2}{*}{$\begin{array}{c}\% \\
\text { Total } \\
\end{array}$} \\
\hline & $\mathrm{HN}$ & ES & TL & $\mathrm{HN}$ & ES & TL & $\mathrm{HN}$ & ES & $\mathrm{TL}$ & $\mathrm{HN}$ & ES & TL & \\
\hline Channel catfish & 9.1 & & 1.6 & & & & & & & & & & 0.5 \\
\hline Flathead catfish & 18.2 & & 3.3 & 33.3 & 1.1 & 5.6 & 30.0 & & 28.6 & 33.3 & & 9.7 & 7.7 \\
\hline White bass & & & & & & & & & & 22.2 & & 6.5 & 0.9 \\
\hline Warmouth & 9.1 & & 1.6 & & & & & & & & & & 0.5 \\
\hline Bluegil1 & 18.2 & & 3.3 & & & & & & & & & & 0.9 \\
\hline Freshwater drum & 9.1 & & 1.6 & 33.3 & & 4.6 & 20.0 & & 19.0 & & & & 4.5 \\
\hline Striped mullet & & & & & 1.1 & 0.9 & & & & & 4.5 & 3.2 & 0.9 \\
\hline
\end{tabular}

Total number caught:

Number of species:

$\begin{array}{rrrrrrrrrrrrr}11 & 50 & 61 & 15 & 93 & 108 & 20 & 1 & 21 & 9 & 22 & 31 & 221 \\ 7 & 3 & 10 & 5 & 7 & 11 & 5 & 1 & 6 & 5 & 6 & 9 & 22\end{array}$


Table 14

Relative Abundance of Fish Captured at Island 88

Natural Bank by Sampling Date and Gear*

\begin{tabular}{|c|c|c|c|c|c|c|c|c|c|c|c|c|c|}
\hline \multirow[b]{2}{*}{ Species } & \multicolumn{3}{|c|}{$\begin{array}{c}\text { Apr } 79 \\
\%\end{array}$} & \multicolumn{3}{|c|}{$\begin{array}{c}\text { Jun } 79 \\
\%\end{array}$} & \multicolumn{3}{|c|}{$\begin{array}{c}\text { Sep } 79 \\
\%\end{array}$} & \multicolumn{3}{|c|}{$\begin{array}{c}\text { Nov } 79 \\
\%\end{array}$} & \multirow{2}{*}{$\begin{array}{c}\% \\
\text { Total } \\
\end{array}$} \\
\hline & $\mathrm{HN}$ & ES & TL & $\mathrm{HN}$ & ES & TL & $\mathrm{HN}$ & ES & TL & $\mathrm{HN}$ & ES & TL & \\
\hline Longnose gar & & & & & 9.1 & 2.3 & & 50.0 & 5.3 & & & & 1.3 \\
\hline Shortnose gar & 8.0 & & 3.0 & & & & & & & & & & 1.3 \\
\hline American ee1 & 8.0 & & 3.0 & & & & 11.8 & & 10.5 & & & & 2.7 \\
\hline Skipjack herring & 4.0 & & 1.5 & & 18.2 & 4.5 & & & & & 5.9 & 5.0 & 2.7 \\
\hline Gizzard shad & 28.0 & 100.0 & 73.1 & & 18.2 & 4.5 & & & & & 76.5 & 65.0 & 42.7 \\
\hline Threadfin shad & & & & & 18.2 & 4.5 & & & & & & & 1.3 \\
\hline Goldeye & & & & & & & & & & & 11.8 & 10.0 & 1.3 \\
\hline Carp & & & & & & & 5.9 & & 5.3 & & & & 0.7 \\
\hline Mississippi silvery minnow & & & & & & & & & & & 5.9 & 5.0 & 0.7 \\
\hline Blue sucker & & & & & & & 5.9 & & 5.3 & & & & 0.7 \\
\hline Smal1mouth buffalo & & & & 3.0 & 9.1 & 4.5 & & & & & & & 1.3 \\
\hline Bigmouth buffalo & 4.0 & & 1.5 & & & & & & & & & & 0.7 \\
\hline Blue catfish & 12.0 & & 4.5 & 6.1 & & 4.5 & 17.6 & & 15.8 & 33.3 & & 5.0 & 6.0 \\
\hline Channel catfish & & & & 3.0 & & 2.3 & & & & & & & 0.7 \\
\hline Flathead catfish & 4.0 & & 1.5 & 33.3 & & 25.0 & 17.6 & & 15.8 & 33.3 & & 5.0 & 10.7 \\
\hline
\end{tabular}

* Gear types are identified in column headings as follows: $\mathrm{ES}=$ electroshocker; HN = hoop net; TL = total for all gear types. 
Table 14 (Concluded)

\begin{tabular}{|c|c|c|c|c|c|c|c|c|c|c|c|c|c|}
\hline \multirow[b]{2}{*}{ Species } & \multicolumn{3}{|c|}{$\begin{array}{c}\text { Apr } 79 \\
\%\end{array}$} & \multicolumn{3}{|c|}{$\begin{array}{c}\text { Jun } 79 \\
\%\end{array}$} & \multicolumn{3}{|c|}{$\begin{array}{c}\text { Sep } 79 \\
\%\end{array}$} & \multicolumn{3}{|c|}{$\begin{array}{c}\text { Nov } 79 \\
\%\end{array}$} & \multirow{2}{*}{$\begin{array}{c}\% \\
\text { Total } \\
\end{array}$} \\
\hline & $\mathrm{HN}$ & ES & TL & $\mathrm{HN}$ & ES & TL & $\mathrm{HN}$ & ES & $\mathrm{TL}$ & $\mathrm{HN}$ & ES & $\mathrm{TL}$ & \\
\hline White bass & 8.0 & & 3.0 & & & & & & & & & & 1.3 \\
\hline Bluegill & 8.0 & & 3.0 & & 9.1 & 2.3 & 5.9 & & 5.3 & & & & 2.7 \\
\hline White crappie & 12.0 & & 4.5 & & & & & & & & & & 2.0 \\
\hline Freshwater drum & 4.0 & & 1.5 & 54.5 & & 40.9 & 35.3 & & 31.6 & 33.3 & & 5.0 & 17.3 \\
\hline Striped mullet & & & & & 18.2 & 4.5 & & 50.0 & 5.3 & & & & 2.0 \\
\hline
\end{tabular}

Total number caught:

$\begin{array}{lllllllllllll}25 & 42 & 67 & 33 & 11 & 44 & 17 & 2 & 19 & 3 & 17 & 20 & 150\end{array}$

Number of species:

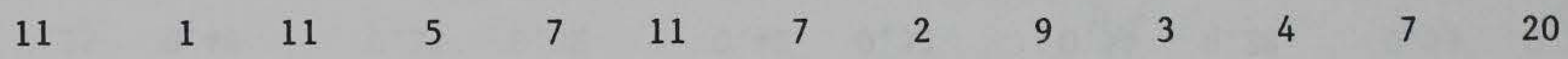


Table 15

Similarity Comparisons of Revetted and Natural Bank Habitats on the Lower Mississippi River

\begin{tabular}{|c|c|c|c|c|c|c|c|c|c|c|c|c|}
\hline \multirow{3}{*}{$\begin{array}{c}\text { Sampling } \\
\text { Date } \\
\end{array}$} & \multicolumn{12}{|c|}{ Location Pair } \\
\hline & \multicolumn{2}{|c|}{ RVL-RVW* } & \multicolumn{2}{|c|}{ RVL-NBA } & \multicolumn{2}{|c|}{ RVL-NBK } & \multicolumn{2}{|c|}{ RVW-NBA } & \multicolumn{2}{|c|}{ RVW-NBK } & \multicolumn{2}{|c|}{ NBA-NBK } \\
\hline & $\mathrm{CC}$ & PS** & $\mathrm{CC}$ & PS & $\mathrm{CC}$ & PS & $\mathrm{CC}$ & PS & $\mathrm{CC}$ & PS & $\mathrm{CC}$ & PS \\
\hline Apr 79 & 0.32 & 0.15 & 0.45 & 0.37 & 0.31 & 0.23 & 0.38 & 0.43 & 0.36 & 0.45 & 0.50 & 0.73 \\
\hline Jun 79 & 0.48 & 0.36 & 0.35 & 0.56 & 0.53 & 0.17 & 0.43 & 0.42 & 0.58 & 0.31 & 0.57 & 0.26 \\
\hline Sep 79 & 0.21 & 0.21 & 0.38 & 0.55 & 0.28 & 0.32 & 0.39 & 0.26 & 0.75 & 0.25 & 0.50 & 0.60 \\
\hline Nov 79 & 0.39 & 0.09 & 0.23 & 0.43 & 0.30 & 0.56 & 0.47 & 0.16 & 0.46 & 0.12 & 0.55 & 0.71 \\
\hline Mean: & 0.35 & 0.20 & 0.35 & 0.48 & 0.35 & 0.32 & 0.42 & 0.32 & 0.54 & 0.28 & 0.53 & 0.58 \\
\hline
\end{tabular}

* Habitat acronyms are explained in Table 1.

** $\quad \mathrm{CC}=$ Coefficient of Community; PS = Percent Similarity. 
Table 16

Relative Abundance of Fish Captured at Matthews Bend

by Sampling Date and Gear*

\begin{tabular}{|c|c|c|c|c|c|c|c|c|c|c|c|c|c|}
\hline \multirow[b]{2}{*}{ Species } & \multicolumn{3}{|c|}{$\begin{array}{c}\text { Apr } 79 \\
\%\end{array}$} & \multicolumn{3}{|c|}{$\begin{array}{c}\text { Jun } 79 \\
\%\end{array}$} & \multicolumn{3}{|c|}{$\begin{array}{c}\text { Sep } 79 \\
\%\end{array}$} & \multicolumn{3}{|c|}{$\begin{array}{c}\text { Nov } 79 \\
\% \\
\end{array}$} & \multirow{2}{*}{$\begin{array}{c}\% \\
\text { Tota1 } \\
\end{array}$} \\
\hline & $\mathrm{HN}$ & ES & $\mathrm{TL}$ & $\mathrm{HN}$ & ES & TL & $\mathrm{HN}$ & ES & $\mathrm{TL}$ & $\mathrm{HN}$ & ES & TL & \\
\hline Paddlefish & & & & 0.5 & & 0.4 & . & & & 0.6 & & 0.1 & 0.2 \\
\hline Spotted gar & & 3.6 & 3.0 & 1.4 & 1.6 & 1.4 & 2.8 & & 1.9 & 9.9 & 3.9 & 4.8 & 3.4 \\
\hline Longnose gar & 20.0 & & 3.0 & & & & 1.9 & & 1.3 & 1.9 & & 0.3 & 0.4 \\
\hline Shortnose gar & 20.0 & & 3.0 & 1.6 & & 1.4 & 5.6 & 3.2 & 4.9 & 5.6 & 0.1 & 0.9 & 1.8 \\
\hline Alligator gar & & & & 0.9 & & 0.8 & & & & t & $t$ & & 0.2 \\
\hline Bowfin & & & & & & & & & & 0.6 & & 0.1 & 0.1 \\
\hline Skipjack herring & 40.0 & & 6.1 & 15.9 & & 13.9 & 9.8 & 4.3 & 8.1 & 18.0 & & 2.7 & 6.5 \\
\hline Gizzard shad & & 89.3 & 75.8 & 63.6 & 85.5 & 66.3 & 50.9 & 74.5 & 58.1 & 9.9 & 70.2 & 61.0 & 62.2 \\
\hline Threadfin shad & & & & & & & & 17.0 & 5.2 & & 8.5 & 7.2 & 4.8 \\
\hline Goldeye & & & & & & & 0.9 & 1.1 & 1.0 & 0.6 & & 0.1 & 0.2 \\
\hline Carp & 20.0 & 3.6 & 6.1 & 0.2 & & 0.2 & & & & 3.1 & 2.8 & 2.8 & 1.8 \\
\hline River carpsucker & & & & 1.4 & & 1.2 & 1.9 & & 1.3 & 18.6 & 0.6 & 3.3 & 2.4 \\
\hline Highfin carpsucker & & & & & & & & & & 0.6 & & 0.1 & 0.1 \\
\hline Sma11mouth buffalo & & & & 0.2 & & 0.2 & 0.5 & & 0.3 & 8.1 & 0.7 & 1.8 & 1.1 \\
\hline Bigmouth buffalo & & & & & & & & & & 3.1 & 0.1 & 0.6 & 0.4 \\
\hline
\end{tabular}

* Gear types are identified in column headings as follows: $\mathrm{ES}=$ electroshocker; HN = hoop net; TL = total for all gear types. 
Table 16 (Concluded)

\begin{tabular}{|c|c|c|c|c|c|c|c|c|c|c|c|c|c|}
\hline \multirow[b]{2}{*}{ Species } & \multicolumn{3}{|c|}{$\begin{array}{c}\text { Apr } 79 \\
\%\end{array}$} & \multicolumn{3}{|c|}{$\begin{array}{c}\text { Jun } 79 \\
\%\end{array}$} & \multicolumn{3}{|c|}{$\begin{array}{c}\text { Sep } 79 \\
\%\end{array}$} & \multicolumn{3}{|c|}{$\begin{array}{c}\text { Nov } 79 \\
\%\end{array}$} & \multirow{2}{*}{$\begin{array}{c}\% \\
\text { Total } \\
\end{array}$} \\
\hline & $\mathrm{HN}$ & ES & TL & $\mathrm{HN}$ & ES & $\mathrm{TL}$ & $\mathrm{HN}$ & ES & $\mathrm{TL}$ & $\mathrm{HN}$ & ES & $\mathrm{TL}$ & \\
\hline Spotted sucker & & & & & & & & & & & 0.1 & 0.1 & 0.1 \\
\hline Blue catfish & & & & 0.7 & & 0.6 & 2.3 & & 1.6 & & & & 0.4 \\
\hline Ye1low bullhead & & & & & & & & & & 0.6 & & 0.1 & 0.1 \\
\hline Channel catfish & & & & 2.1 & & 1.8 & 2.3 & & 1.6 & 5.6 & 0.3 & 1.1 & 1.4 \\
\hline Flathead catfish & & & & & 1.6 & 0.2 & & & & & & & 0.1 \\
\hline White bass & & & & 0.2 & 1.6 & 0.4 & 2.8 & & 1.9 & 6.2 & 0.3 & 1.2 & 1.1 \\
\hline Striped bass & & & & & & & & & & 1.2 & & 0.2 & 0.1 \\
\hline Warmouth & & & & & & & & & & & 0.1 & 0.1 & 0.1 \\
\hline $\begin{array}{l}\text { Orangespotted } \\
\text { sunfish }\end{array}$ & & & & & & & & & & & 0.2 & 0.2 & 0.1 \\
\hline Bluegill & & & & & 9.7 & 1.2 & & & & 1.2 & 7.0 & 6.1 & 3.7 \\
\hline Redear sunfish & & & & & & & & & & 0.6 & pat & 0.1 & 0.1 \\
\hline Largemouth bass & & 3.6 & 3.0 & & & & & & & 1.2 & 1.6 & 1.5 & 0.9 \\
\hline White crappie & & & & 0.2 & & 0.2 & 0.5 & & 0.3 & 0.6 & 1.4 & 1.3 & 0.8 \\
\hline Black crappie & & & & E & & & 0.5 & & 0.3 & & 0.9 & 0.8 & 0.5 \\
\hline Sauger & & & & & & & & & & & 0.1 & 0.1 & 0.1 \\
\hline Freshwater drum & & & & 11.0 & & 9.6 & 17.3 & & 12.0 & 1.9 & 1.1 & 1.2 & 5.1 \\
\hline Total number caught: & 5 & 28 & 33 & 428 & 62 & 490 & 214 & 94 & 308 & 161 & 891 & 1059 & 1890 \\
\hline Number of species: & 4 & 4 & 7 & 14 & 5 & 16 & 14 & 5 & 15 & 22 & 19 & 28 & 31 \\
\hline
\end{tabular}


Table 17

Relative Percent by Weight of the Ten Dominant

Fish Species Captured from Matthews Bend

\begin{tabular}{|c|c|c|c|c|c|}
\hline Species & Apr 79 & Jun 79 & Sep 79 & Nov 79 & Total \\
\hline Gizzard shad & 10.4 & 45.3 & 27.7 & 8.7 & 20.1 \\
\hline Carp & 12.8 & 3.2 & & 26.1 & 16.3 \\
\hline Spotted gar & 2.5 & 10.4 & 6.7 & 17.9 & 13.7 \\
\hline Skipjack herring & 4.1 & 8.0 & 12.8 & 4.8 & 6.6 \\
\hline River carpsucker & & 3.2 & 4.2 & 9.0 & 6.5 \\
\hline Shortnose gar & 3.1 & 4.6 & 19.6 & 3.3 & 5.7 \\
\hline Freshwater drum & & 11.2 & 10.7 & 1.7 & 5.0 \\
\hline Channel catfish & & 3.6 & 4.3 & 3.4 & 3.4 \\
\hline Sma11mouth buffalo & & 1.7 & 0.9 & 4.2 & 2.9 \\
\hline White bass & & 0.3 & 4.7 & 2.8 & 2.3 \\
\hline Total percent: & 32.9 & 91.5 & 91.6 & 81.9 & 82.5 \\
\hline
\end{tabular}


Table 18

Mean Total Length $(\bar{x})$, Range of Lengths $(R)$, and Number of Individuals ( $n$ ) of

Four Species of Fish from Eight Mississippi River Habitat Locations

(Lengths in millimetres)

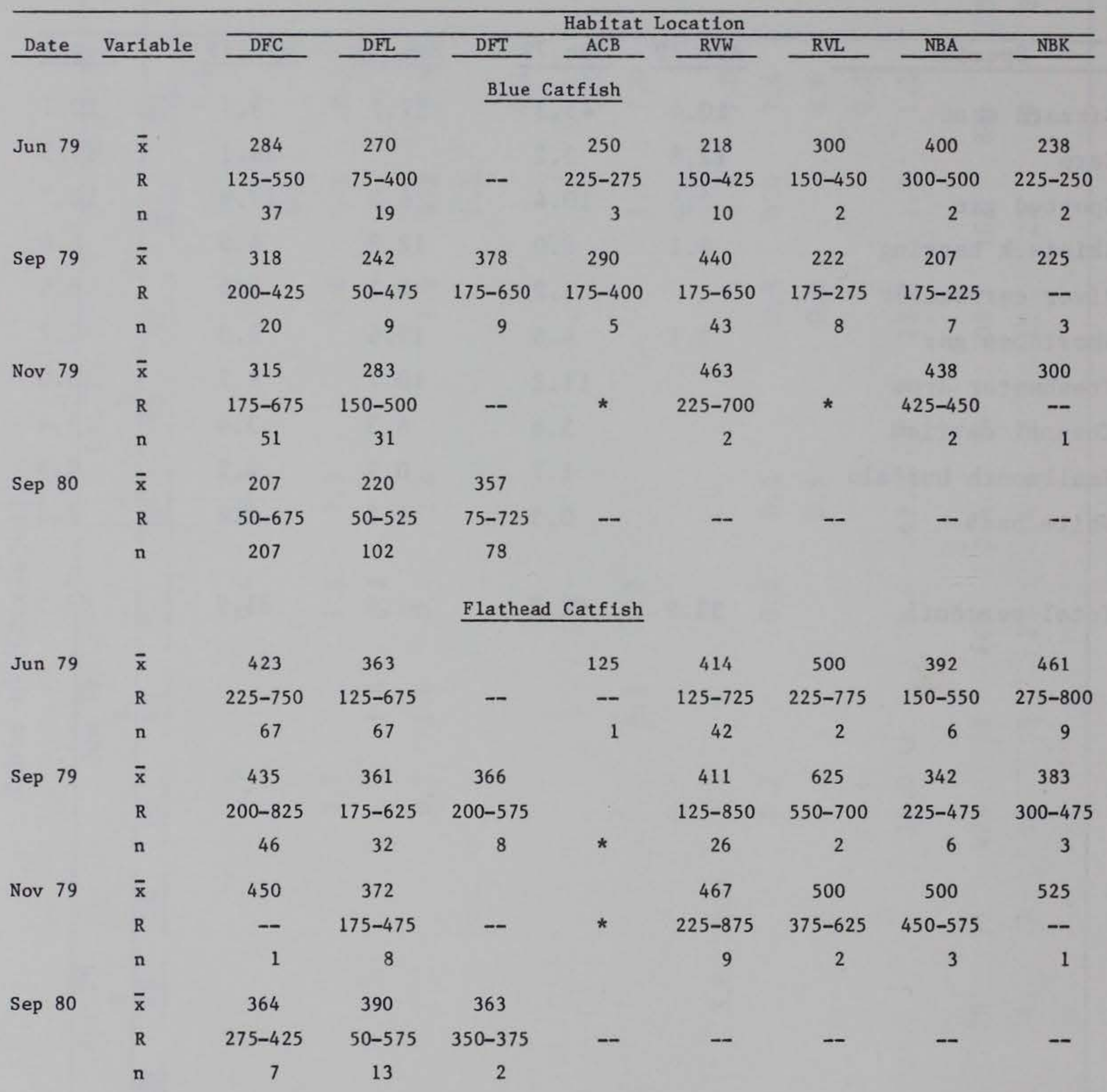


Table 18 (Concluded)

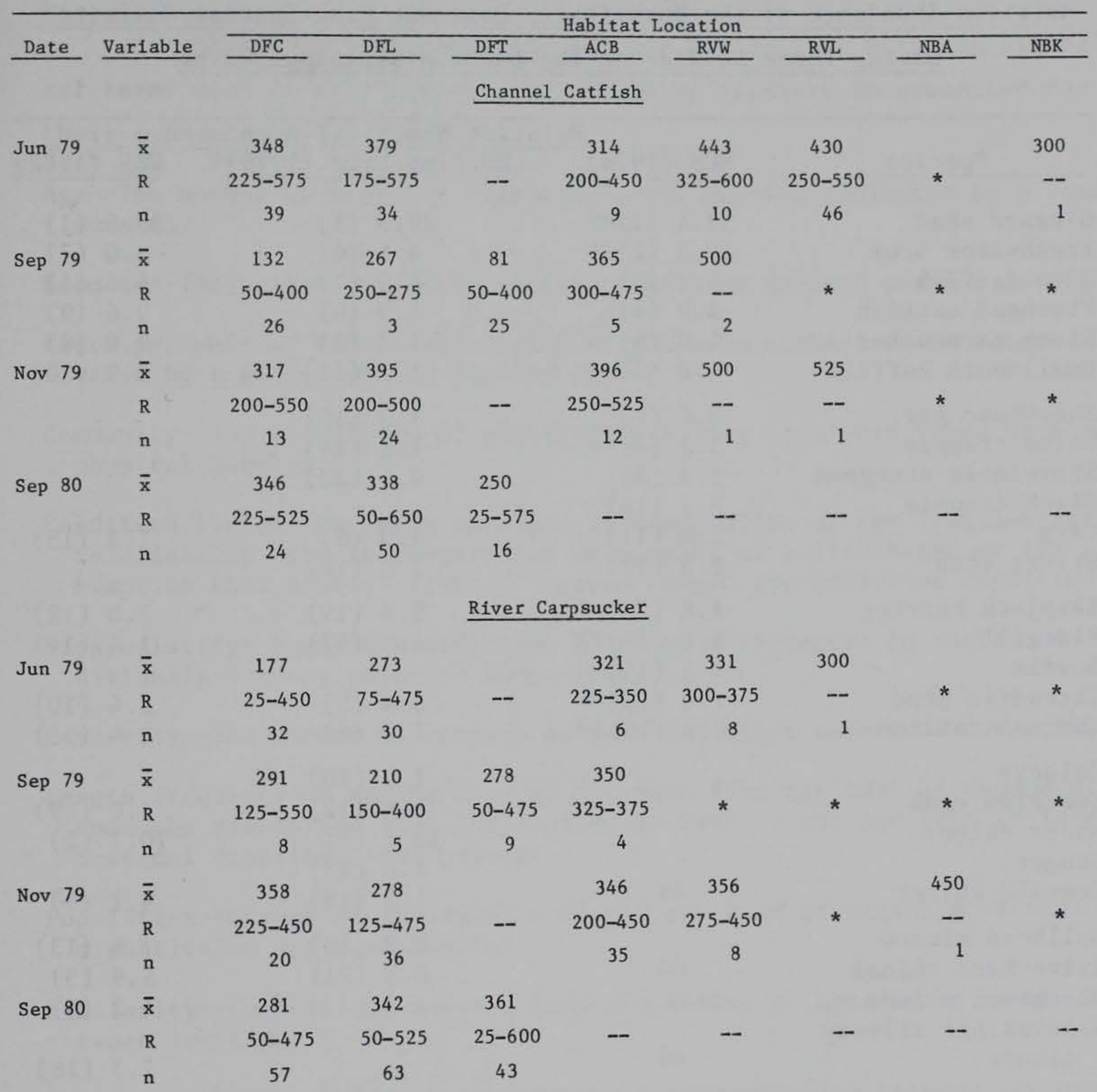

* Sampling accomplished but no fish collected. 
Table 19

Relative Abundance of the Numerically Dominant Fish Species Collected During Three Studies on the Lower Mississippi River

\begin{tabular}{|c|c|c|c|}
\hline & & ative Numerical Abundan & \\
\hline Species & NUS (1974) & CMD/Limnetics (1976)* & WES (1982) \\
\hline Gizzard shad & $37.4(1) \div$ & 20.6 (1) & 35.5 (1) \\
\hline Freshwater drum & $10.3(2) \div *$ & $4.6(6)$ & $3.0(7)$ \\
\hline Blue catfish & $8.3(3)$ & $4.5(7)$ & $4.6(4)$ \\
\hline Flathead catfish & $4.9(4)$ & $1.9(9)$ & $2.6(9)$ \\
\hline River carpsucker & $4.8(5)$ & $14.7(2)$ & $2.6(8)$ \\
\hline Smallmouth buffalo & $4.0(6)$ & $1.7(11)$ & $0.9(20)$ \\
\hline Shortnose gar & $3.6(7)$ & $1.3(15)$ & \\
\hline White crappie & $3.2(8) * *$ & $1.5(14)$ & \\
\hline Shovelnose sturgeon & $2.9(9)$ & $0.5(22)$ & \\
\hline Black crappie & $2.7(10)$ & & \\
\hline Carp & $2.4(11)$ & $4.0(8)$ & $1.3(15)$ \\
\hline Silver chub & $2.3(12)$ & $1.3(16)$ & \\
\hline Skipjack herring & $1.8(13) * \%$ & 0.8 (19) & $2.0(12)$ \\
\hline Bluegill & $1.3(14) * *$ & $1.3(17)$ & $1.4(14)$ \\
\hline Bowfin & $1.2(15)$ & & \\
\hline Threadfin shad & $1.0(16) \% *$ & $6.4(5)$ & $2.4(10)$ \\
\hline Channel catfish & $0.9(17) * *$ & $7.2(4)$ & $2.4(11)$ \\
\hline Goldeye & & $1.9(10)$ & \\
\hline Speckled chub & & $1.6(12)$ & 1.0 (19) \\
\hline River shiner & & $13.2(3)$ & $10.1(2)$ \\
\hline Sauger & & $1.6(13)$ & \\
\hline Emerald shiner & $*$ & $1.0(18)$ & $4.1(6)$ \\
\hline Bullhead minnow & & $0.8(20)$ & $1.6(13)$ \\
\hline Silverband shiner & $* *$ & $0.8(21)$ & 5.9 (3) \\
\hline Blacktail shiner & & & $4.2(5)$ \\
\hline $\begin{array}{l}\text { Mississippi silvery } \\
\text { minnow }\end{array}$ & $* *$ & & $1.3(16)$ \\
\hline White bass & $* *$ & & 1.2 (17) \\
\hline Inland silversides & $*$ & & $1.1(18)$ \\
\hline Red shiner & $* *$ & & \\
\hline Mooneye & $\%$ & & \\
\hline Cypress minnow & 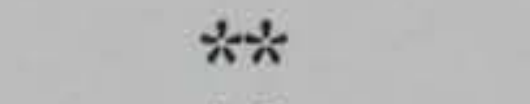 & & \\
\hline Silver chub & $* *$ & & \\
\hline Cumulative percentage: & 93.0 & 93.2 & 89.2 \\
\hline
\end{tabular}

Note: Rank abundance given in parentheses for each study.

* James, Miss., site only.

** Relatively abundant species collected during nearshore seining, but not included in relative numerical abundances presented. 


\section{APPENDIX A: GLOSSARY OF TERMS*}

For the benefit of those who may not be familiar with the biological terms used in this report, the following glossary is presented for their convenience.

Age--The number of years of life completed, usually indicated by a roman numeral.

Biomass--The weight of a fish stock, or of some defined portion of it.

Catch per unit of effort--The catch of fish, in numbers or in weight, taken by a given unit of fishing effort.

Community--Any assemblage of populations living in a prescribed area or physical habitat.

Condition factor--An index obtained by computation of the length-weight relationship used to compare the well being of a fish based on the assumption that heavier fish of a given length are in better condition.

Dissimilarity--Numeric coefficient based on differences in number of individuals for any pairwise comparison.

Diversity--The number of species present and their numerical composition.

Length frequency--A method used to estimate fish age that is dependent upon the assumption that the lengths of fish of one age tend to form a normal distributional pattern.

Population--Groups of individuals of any one kind of organism occupying a particular space or habitat.

Similarity--Coefficient derived from the number of species in common between locations.

Total length--The greatest distance in a straight line between the most anteriorly projected part of the head and the farthest tip of the caudal fin.

Year class--The fish spawned or hatched in a given year.

* From Ricker (1975) and Green (1979). 